\title{
DESCRIÇÃO DA ESTRUTURA ANATÔMICA DO LENHO E SUA APLICAÇÃO NA IDENTIFICAÇÃO DE ESPÉCIES ARBÓREAS DO CERRADO E DA MATA ATLÂNTICA DO ESTADO DE SÃO PAULO
}

\author{
GraZiela Cury
}

Dissertação apresentada à Escola Superior de Agricultura "Luiz de Queiroz", Universidade de São Paulo, para obtenção do título de Mestre em Recursos Florestais, Área de Concentração: Recursos Florestais, com opção em Tecnologia de Produtos Florestais.

PIRACICAB A

Estado de São Paulo

Abril - 2001 


\title{
DESCRIÇÃO DA ESTRUTURA ANATÔMICA DO LENHO E SUA APLICAÇÃO NA IDENTIFICAÇÃO DE ESPÉCIES ARBÓREAS DO CERRADO E DA MATA ATLÂNTICA DO ESTADO DE SÃO PAULO
}

\section{Graziela Cury}

Bióloga

Orientador: Prof. Dr. MARIO TOMAZELLO FILHO

\author{
Dissertação apresentada à Escola Superior \\ de Agricultura "Luiz de Queiroz", Universidade \\ de São Paulo, para obtenção do título de \\ Mestre em Recursos Florestais, Área de \\ Concentração: Recursos Florestais, com \\ opção em Tecnologia de Produtos Florestais.
}

P I R A C I C A B A

Estado de São Paulo

Abril-2001 
Dados Internacionais de Catalogação na Publicação (CIP)

DIVISÃO DE BIBLIOTECA E DOCUMENTAÇÃO - ESALQ/USP

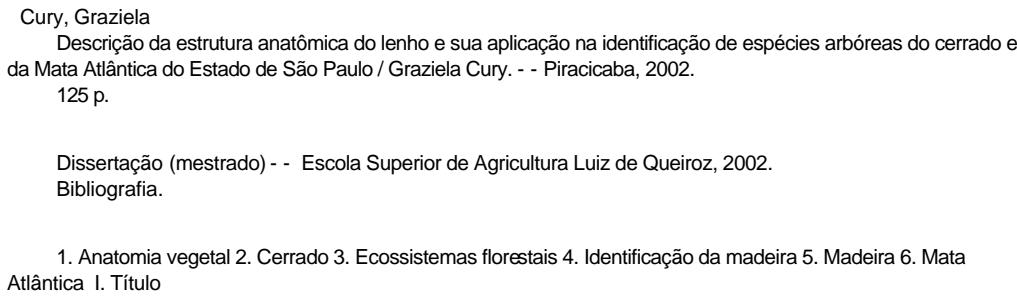

CDD 634.983

"Permitida a cópia total ou parcial deste documento, desde que citada a fonte - $\mathrm{O}$ autor" 
Aos me us pais, Maria Francisca e Wladimir, os verdadeiros responsáve is por este trabalho, Dedico 


\section{Agradecimentos}

À Fundação de Amparo a Pesquisa do Estado de São Paulo pela concessão da bolsa de Mestrado.

Ao Prof. Dr. Mario Tomazello Filho pela dedicação e apoio na orientação deste trabalho.

Aos administradores da Estação Ecológica de Ibicatu, Reserva Estadual de Porto Ferreira, Arboreto Experimental da Duratex, Estação Experimental de Tupi, Estação Experimental de Santa Rita do Passa Quatro, e Reserva Florestal da Mata Santa Genebra por permitirem as coletas de material.

A Carolina e Fábio por me mostrarem a área de coleta no Sítio São Luis.

Ao Prof. Dr. Cláudio Sérgio Lisi por seus conselhos e por me ensinar a usar o extrator de amostras de madeira.

Ao técnico de Laboratório de Laminação de Madeira da ESALQ/USP, Valdir Ferreira Caldas, pelo auxílio no uso do extrator de amostras de madeiras.

Ao técnico do Laboratório de Propriedade Física da Madeira da ESALQ/USP, Luis Eduardo Facco, pelo auxílio nas coletas das amostras de madeira.

Ao aluno de Graduação em Engenharia Florestal da ESALQ/USP, Marcelo Antonio de Pinho Ferreira, pelo auxílio nas coletas de material botânico e identificação do mesmo.

Ao funcionário do Centro de Informática do Departamento de Ciências Florestais da ESALQ/USP, Ivo Rosa Filho, pela constante ajuda em computação na elaboração do trabalho.

Ao estagiário de computação do Laboratório de Anatomia de Madeira da ESALQ/USP, Ricardo Antoniali, pela paciência em me ajudar com o computador. 
A técnica do Laboratório de Anatomia de Madeiras da ESALQ/USP, Maria Aparecida Rizzato Chaves Bermudez, pela amizade, pelo apoio, pelos cafés e pelo auxílio na confecção das lâminas histológicas de madeira.

Ao chefe do Agrupamento de Preservação de Madeiras do IPT, Sérgio Brazolin, por permitir o uso do Analisador de Imagens.

Aos amigos do IPT Geraldo, Adriana e Márcio pelos conselhos e empréstimos de livros.

Ao técnico do Laboratório de Anatomia de Madeiras do IPT, Francisco Pereira da Silva, meu primeiro professor nesta disciplina.

Ao querido Antônio Carlos Franco Barbosa pela sua amizade, seus ensinamentos e seus conselhos nas horas difíceis, além do auxílio na confecção das lâminas histológicas de madeira.

Aos colegas e amigos da ESALQ: Lígia, Vivian, Bibiana, Bianca, Cristiane, Renato, Ariel, Viviane, Raquel, Percy, e os que eu possa ter esquecido.

Ao meu querido namorado Gustavo Lania Guapo pelo carinho e paciência que sempre teve comigo nas horas difíceis.

A minha amada família que viveu comigo todas as alegrias e tristezas durante o meu Mestrado, sempre me apoiando de forma incondicional.

A todos que de forma direta e indireta participaram da realização deste trabalho. 


\section{SUMÁRIO}

Página

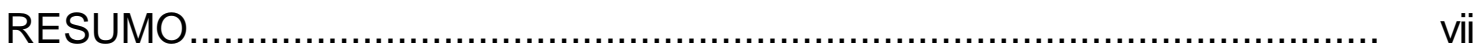

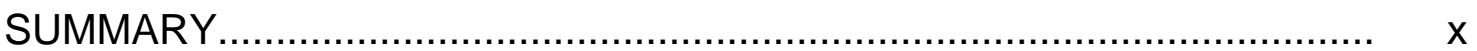

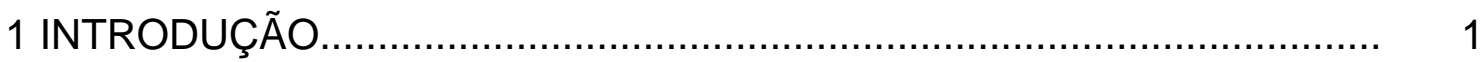

2 REVISÃO DE LITERATURA ............................................................ 3

2.1 Os ecossistemas florestais cerrado e mata atlântica no Estado de São

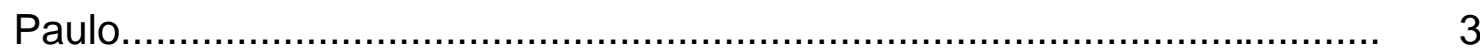

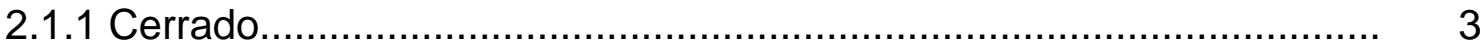

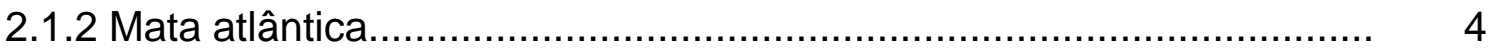

2.2 Anatomia do lenho: importância e aplicação para a identificação das espécies arbóreas......................................................................... 6

2.3 Parâmetros para o estudo e descrição da estrutura anatômica do lenho lenho de espécies arbóreas......................................................................... 8

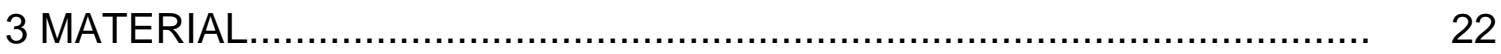

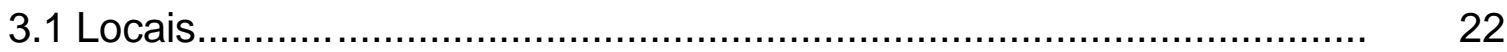

3.2 Espécies selecionadas.............................................................. 24

3.3 Principais usos das espécies selecionadas....................................... 26

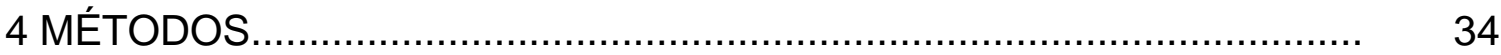

4.1 Coleta do material botânico e amostras de madeira............................ 34

4.1.1 Material botânico.................................................................... 34

4.1.2 Amostras de madeira............................................................ 34

4.2 Análise do material botânico e amostras de madeira........................... 37

4.2.1 Material botânico....................................................................... 37 
5 RESULTADOS...

5.1 Descrição anatômica macro e microscópica das espécies selecionadas

5.2 Chave para identificação macroscópica das espécies

selecionadas (método tradicional).

83

5.3 Chave para identificação microscópica das espécies

selecionadas (identificação por computador)...

6 DISCUSSÃO

103

6.1 Em relação àmetodologia de coleta das amostras de madeira. 103

6.2 Em relação æ̀s estruturas anatômicas 103

7 CONCLUSÕES 112

REFERÊNCIAS BIBLIOGRÁFICAS. 114 APÊNDICE. 125 


\title{
"DESCRIÇÃO DA ESTRUTURA ANATÔMICA DO LENHO E SUA APLICAÇÃO NA IDENTIFICAÇÃO DE ESPÉCIES ARBÓREAS DO CERRADO E DA MATA ATLÂNTICA DO ESTADO DE SÃO PAULO"
}

\author{
Autora: GRAZIELA CURY \\ Orientador: Prof. Dr. MARIO TOMAZELLO FILHO
}

RESUMO

A biodiversidade do Brasil é assunto que vem cada vez mais sendo discutido no sentido da sua preservação, conservação e uso sustentável. A anatomia da madeira, importante ramo da dendrologia, é uma ferramenta essencial para a determinação da composição florística, porque a identificação taxonômica é restringida e limitada pela dificuldade de se encontrar material reprodutivo ou flores nas espécies arbóreas, além da falta de informações sobre a verdadeira identidade das árvores quando jovens e o acesso difícil em campo. Pelo exposto, este projeto de pesquisa tem como objetivos relacionar as espécies florestais mais importantes do cerrado e mata atlântica do Estado de São Paulo, coletar amostras de lenho para a caracterização anatômica macro e microscópica, desenvolver uma chave de identificação dessas espécies e proporcionar um melhor conhecimento dos ecossistemas florestais que ocorrem no Estado de São Paulo. Na Estação Ecológica de Ibicatu, na Reserva Estadual 
de Porto Ferreira, no Arboreto Experimental da Duratex, na Estação Experimental de Tupi na Estação Experimental de Santa Rita do Passa Quatro, na Reserva Florestal de Santa Genebra e na área do Sítio São Luiz (Jundiaí SP) foram coletados materiais botânicos e amostras de madeira por método não destrutivo, para realizar as descrições anatômicas macro e microscópicas do lenho das espécies arbóreas desses ecossistemas florestais. 
" Description of The Anatomical Structure of The Log And Its Application In The Identification of Arboreal Species from The Cerrado and The Mata Attântica of The State of São Paulo "

\author{
Author: GRAZIELA CURY \\ Adviser: Prof. MARIO TOMAZELLO FILHO
}

\title{
SUMMARY
}

The bio diversity of Brazil is a subject that is being argued more frequently in the direction of its preservation, conservation and sustainable use. The anatomy of the wood, important branch of Dendrology, is an essential tool for the determination of the floristic composition, since the taxonomic identification is restricted and limited for the difficulties of finding reproductive material or flowers in the arboreal species, besides the lack of information on the true identity of young trees and the difficult access in field. For the displayed one, this design of research has as objective to relate the more important forest species of the Cerrado (open pasture) and the Mata Atlântica (Atlantic Forest) of the State of São Paulo, to collect samples of log for the anatomical macro and microscopic characterization, to develop a key of identification of these species and to provide one better knowledge of the forest ecosystems that occur in the State of São Paulo. In the Ecological Station of Ibicatu, in the State Hold of Port Blacksmith, in 
the Experimental Arboretum of Duratex, in the Experimental Station of Tupi, in the Experimental Station of Santa Rita of Passa Quatro, in the Forest Hold of Santa Genebra and in the area of the Sao Luiz small farm in the city of Jundiaí. Wooden samples and botanical material had been collected by non destructive method and, to carry out macro and microscopic anatomical descriptions of the log of the arboreal species of these forest ecosystems. 


\section{INTRODUÇÃO}

As florestas tropicais são, entre os maiores "habitats", os mais ricos em espécies e os que estão em maior perigo pela constante exploração dos seus recursos. Desse modo, a diversidade biológica deve ser tratada como um assunto global para ser classificada, utilizada e, acima de tudo, preservada (Wilson \& Peter, 1995).

Deste modo, é necessário inventariar e caracterizar a biodiversidade vegetal, definindo os mecanismos para a sua conservação, seu potencial econômico e sua utilização sustentável. Para o estudo da diversidade florística, no entanto, Santos et al. (1998) evidenciam as grandes dificuldades que o território brasileiro impõe na distinção e denominação de seus componentes. Dessa forma, são poucos os profissionais habilitados a identificar um grande número de árvores ainda no campo.

Giardi ${ }^{1}$, citado por Pinheiro et al. (1991), evidencia a dificuldade de se encontrar material florido para a identificação das espécies arbóreas. Por outro lado, Finger et al. (1979) demonstram que muitas pesquisas no campo florestal encontram dificuldades de realização por falta de informações sobre a verdadeira identidade das plantas quando jovens, além de estudos que demonstram que as árvores apresentam características morfológicas distintas em cada fase do seu desenvolvimento.Somado a isso vale destacar o acesso difícil às estruturas reprodutivas em algumas matas para a sua coleta, como um fator que limita a identificação de espécies arbóreas .

Como uma ferramenta da dendrologia, a anatomia de madeira tem se

${ }^{1}$ Giardi, C., 1975 
constituído em um fabuloso caminho para o estudo das florestas tropicais, possibilitando a identificação das espécies pelo seu lenho (Ramalho, 1975). A anatomia da madeira é o ramo da ciência que procura conhecer o arranjo estrutural dos diversos elementos que constituem o lenho ou xilema. A identificação de espécies através das suas madeiras, que se baseia nos caracteres anatômicos do lenho e processa-se sobre uma amostra de tronco, independente de quaisquer outras características do vegetal (Divisão de Madeiras - IPT, 1985). Pode ser um eficiente método para descrever as espécies de árvores das florestas, conhecendo melhor a vegetação florestal e contribuindo, dessa maneira, para a sua preservação.

Além disso, dos recursos biológicos das florestas tropicais, a madeira é um dos produtos mais valorizados, sendo uma das partes nobres da árvore (Paula \& Alves, 1997). Em nível mundial, segundo Furtado et al. (1992), a remoção da madeira das florestas tropicais para uso industrial tem aumentado continuamente desde o fim da $2^{\mathrm{a}}$ Guerra Mundial, com tendência a aumentar neste século. Levando em consideração as vantagens da identificação de espécies arbóreas pela anatomia do lenho e as dificuldades impostas por outros métodos, a anatomia da madeira vem como uma excelente ferramenta que pode auxiliar de forma direta na identificação de árvores.

Pelo exposto, este trabalho tem como objetivos (i) relacionar as espécies florestais mais representativas e importantes - como as com potencial para a produção de fármacos, frutos, madeira - dos ecossistemas cerrado e mata atlântica do Estado de São Paulo; (ii) coletar amostras de madeira - por método não-destrutivo - e material botânico, para a caracterização da sua estrutura anatômica macro e microscópica; (iii) desenvolver chaves de identificação (macro e microscópica) dessas espécies florestais, através da estrutura anatômica de suas madeiras, como instrumento de suporte para a identificação das árvores em campo. 


\section{REVISÃO DE LITERATURA}

\subsection{Os ecossistemas florestais: cerrado e mata atlântica no Estado de São Paulo}

\subsubsection{Cerrado}

As regiões de cerrado localizam-se no Centro-Oeste brasileiro nos Estados de Minas Gerais, Mato Grosso e Goiás e, em partes menores, nos de São Paulo, Paraná, Maranhão e Piauí (Joly, 1970). Tem vegetação rasteira, com raros arbustos, ou árvores de pouca altura, troncos tortuosos, galhos baixos e retorcidos. O cerrado é o segundo maior bioma do Brasil, superado apenas pela Amazônia. (Caruso, 1997).

Rizzini (1963), citado por Goodland \& Ferri (1979), elaborou a mais completa lista de espécies de todas as áreas brasileiras de cerrado que até então tinham sido estudadas. Esta lista contém cerca de 600 espécies vegetais lenhosas, pertencentes a 242 gêneros.

Goodland \& Ferri (1979) constataram que no cerrado ocorrem 16 famílias com 5 ou mais gêneros e mais de 10 espécies que representam essa flora, com 11 dessas famílias expressivas em escala mundial e no cerrado. As 5 famílias restantes não são significativas em termos mundiais absolutos estando, portanto, "super-representadas" no cerrado, o que as torna mais características desta vegetação. Essas famílias são as das Bignoniaceae, Vochysiaceae, Malpighiaceae, Annonaceae e Melastomataceae.

Hoje o cerrado brasileiro é considerado o segundo "hotspot" do Brasil,

sendo a $2^{\mathrm{a}}$ maior ecorregião do Brasil, com extensão original de $1.783 .169 \mathrm{~km}^{2}$, ocupando $21 \%$ da área do Pais. Consiste principalmente de árvores e mata de 
savana e, ocasionalmente, tem uma estrutura como a da floresta. Esse ecossistema está incluído entre os "hotspots" pela sua flora, considerada uma das regiões mais ricas de toda a savana tropical e com altos níveis de endemismo. Mendonça \& Queiroz (1997) listam 6.387 angiospermas no cerrado, com a diversidade vegetal total estimada em 10.000 espécies, das quais 44.00 (44\%) são endêmicas (Mittermeier et al., 2000).

Em São Paulo, as formações do complexo cerrado não são contínuas, ocorrendo como encraves, em meio à floresta mesófila que é o bioma predominante no Estado. O cerrado paulista em sua expressão mais contínua ocorria nas Regiões Administrativas de Ribeirão Preto, Sorocaba, Bauru e Campinas. Atualmente verifica-se a inexistência ou a mínima ocorrência de cerrados no extremo oeste, curso superior do Rio Tietê, nas regiões que margeiam o Rio Paraná e nas regiões litorâneas, incluindo também o Vale do Rio Paraíba, região de São Paulo e Bragança Paulista (Kronka, 1998).

\subsubsection{Mata atlântica}

A mata atlântica é considerada um dos refúgios de biodiversidade mais significativos do mundo e declarada pela UNESCO como Reserva da Biosfera, sendo abrigo de muitas espécies que só ocorrem nesse ambiente e sua ocorrência beneficia na qualidade do ar, na retenção da água e no equilíbrio do clima.

A mata atlântica estende-se do paralelo $5^{\circ}$ ao $30^{\circ}$ latitude Sul, com as condições ecológicas variando desde os ecossistemas das planícies litorâneas até os das escarpas atlânticas ou dos tabuleiros interiores. Atualmente a soma das parcelas dispersas da floresta atlântica não alcança mais do que 10.000 $\mathrm{km}^{2}$, ou seja, menos do que $3 \%$ da sua área original. Praticamente desapareceu nos Estados do Rio Grande do Norte, Paraíba, Pernambuco, Alagoas e Sergipe onde restam apenas algumas áreas com floresta secundária. Reduziurse a poucas áreas na Bahia e no Espírito Santo, sendo que com diversos graus de alteração ou degradação remanesce nas encostas mais inacessíveis da Serra 
do Mar nos Estados do Rio de Janeiro, São Paulo, Paraná e Santa Catarina, praticamente não mais existindo no Rio Grande do Sul. Nas restingas, de norte a sul, é formada por árvores altas com até $25 \mathrm{~m}$ de altura, com copas extensas e irregulares que se tocam e se fecham. Entre a copa e o solo coberto por folhas e detritos vegetais, existe um estrato inferior pouco denso, com arvoretas, arbustos, palmeiras e grande quantidade de epífitas. Entre outras árvores dominam as canelas, figueiras, leiteiras, paineiras e angicos; dentre o estrato arbustivo, aparecem as sorocas, muricis, abaneiros, angelins, arco-de-pipa, folha-redonda, tento e pitangas; gravatás, orquídeas, cactus e caetés embelezam o estrato inferior ( $A C \& M, 1984$ ).

Joly et al. (1990) citado por Born (1992) constata o alto nível de endemismo da floresta pluvial tropical atlântica sendo 55\% das espécies arbóreas e $40 \%$ das famílias de espécies não arbóreas. Com relação às palmeiras e bromélias, esse percentual aumenta pois, de cada 3 espécies, 2 ocorrem exclusivamente nesta formação.

A floresta atlântica brasileira é um dos ecossistemas mais ameaçados do planeta e está em risco de uma destruição em larga escala. Quando os europeus chegaram no Brasil no século XVI a floresta atlântica altamente diversa cobria um milhão de $\mathrm{km}^{2}$ da costa leste e sul, representando $12 \%$ do território brasileiro. Hoje essas florestas foram fragmentadas e reduzidas para cerca de $7 \%$ do seu tamanho original, apesar de abrigar um dos mais altos níveis de diversidade biológica com $7 \%$ das espécies do mundo, muitas endêmicas e ameaçadas de extinção.

Endêmicas a esse ecossistema são 51 espécies de mamíferos, 160 espécies de pássaros, $53 \%$ das árvores, $64 \%$ das palmeiras e $74 \%$ das bromélias. O domínio da floresta atlântica pode ser subdividido em 2 regiões principais pelo tipo de vegetação e pelas características geográficas, sendo (i) Floresta Tropical Perene Mesófila (cobria grande parte das encostas leste até a linha costeira, com alcance limitado por fatores climáticos e encontrada em elevações baixas a médias, precipitação anual média por volta de $2000 \mathrm{~mm}$, 
temperaturas anuais médias de $16-19{ }^{\circ} \mathrm{C}$ ); (ii) Floresta Tropical Semidecídua Mesófila (estende-se do limite oeste das montanhas costeiras até a mata de planalto, originalmente em grandes áreas dos Estados de Minas Gerais, Rio de Janeiro, São Paulo e Paraná, com precipitação anual de 1000 a 1500 mm, com pronunciada estação úmida de 5 a 6 meses, o que corresponde à estação de inverno quando a precipitação é de $50 \mathrm{~mm} / \mathrm{mês}$ ). De modo geral, a maior parte da cobertura florestal remanescente na Mata Atlântica encontra-se nas encostas ao longo da costa (Cullen, 1997).

A Mata Atlântica ainda é a $3^{\mathrm{a}}$ maior formação vegetal do Brasil (depois da Amazônia e do Cerrado) ocupando $13 \%$ do território nacional e sendo a $2^{\mathrm{a}}$ de maior diversidade biológica depois da região Amazônica. Análise recente do "World Wildlife Fund" (BSP et al., 1995) divide esse "hotspot" em 2 ecorregiões principais, a Floresta Atlântica Costeira (com cerca de $22,5 \%$ do ecossistema) e a Floresta Atlântica Interior (inclui as florestas nos vários alcances de montanhas e estende-se até o leste do Paraguai e Misiones na Argentina). A floresta atlântica tem níveis extremamente altos de diversidade e endemismo, estimando-se em 20.000 espécies, das quais mais de 6.000 são endêmicas (Mittermeier et al., 2000).

\subsection{Anatomia do lenho: importância e aplicação para a identificação de espécies arbóreas}

O avanço da Anatomia da Madeira deveu-se inicialmente, e em grande parte, aos fatores econômicos, com significativo número de pesquisas feitas por instituições governamentais baseando-se em madeiras com importância ou potencial industrial. A necessidade do conhecimento da riqueza dos recursos madeireiros dos países tropicais tem sido detectada há décadas e em conseqüência, foi a pesquisa de seus recursos associada com as descrições das madeiras mais importantes (Jane, 1934).

O desenvolvimento da Anatomia da Madeira revela a necessidade de um sistema no qual todas as espécies sejam classificadas de acordo com suas 
relações mútuas para formar a base para a identificação. Os primeiros esquemas permitiram uma classificação não integrante, no qual o número de espécies de madeiras era acrescentado arbitrariamente. Seguiram-se os métodos elaborados com o uso de lentes de aumento e dos que apresentam fotos da estrutura microscópica da madeira. Esses esquemas de descrição são os holandeses como os de Moll e Janssonius (1906), Pfeiffer (1917 e 1926), Beekman (1920), Dan Berger e Beekman (1922), Beversluis (1925) e Bianchi (1931); os anglossaxões como os de Swain (1927), Record (1934), Clarke (1938), Record e Chattaway (1939); os franceses como os de Perrot (1921 1922), Lecomte (1923) e Normand (1934) (Pfeiffer \& Varossieau, 1946).

A identificação da madeira é realizada através da observação das características organolépticas e anatômicas macro e microscópicas, em suas superfícies transversal e longitudinais. Angyalossy - Alfonso (1987) cita o uso de chaves dicotômicas para identificação de espécies pelas suas madeiras.

Um outro método, que mostrou eficiência, é o estereológico, que envolve técnicas geométricas e estatísticas, bem como de equações para descrever a estrutura anatômica das madeiras de maneira numérica (Chimelo, 1978).

Outras metodologias foram desenvolvidas para a identificação de espécies pelas suas madeiras, como a dos cartões perfurados e, posteriormente, com a aplicação do computador. É um processo de extraordinário valor no Brasil que contava, até há poucos anos, com a experiência e capacidade de memória de poucos anatomistas de madeira, autodidatas e que identificavam as espécies a partir da madeira com relativa facilidade. Hoje muitos anatomistas usam ferramentas tradicionais como as chaves de identificação, cartões perfurados, além de manuais e atlas fotográficos. No entanto, a identificação de madeiras com o auxílio do computador já vem sendo realizada em vários países, com destaque para os EUA, Alemanha, Inglaterra, França, Japão e Venezuela. Esse processo surgiu com o desenvolvimento da informática e dos avanços na área de softwares podendo ser citado no Brasil o IMAC - Identificação de Madeiras Brasileiras 
com Auxílio do Computador. Neste sistema foram catalogadas 254 espécies de madeiras de folhosas visando facilitar a sua identificação sendo escolhidas 132 características da madeira (110 anatômicas e 22 relacionadas com a coloração do cerne, ocorrência, etc.) (Chimelo et al., 1993). Outro exemplo é o "Manual de Referência de Identificação de Madeiras com o Auxílio de Computador", elaborado por Wheeler et al. (1986) onde, também, são usadas características anatômicas de madeiras para facilitar a identificação das espécies.

\subsection{Parâmetros para o estudo e descrição da estrutura anatômica do lenho de espécies arbóreas}

A lista para a identificação de madeiras de folhosas da IAWA (1989) relaciona todas as características microscópicas da madeira que devem ser levadas em consideração na descrição anatômica. As características apresentadas na lista foram conceituadas por muitos autores e a revisão apresenta os conceitos com destaque æ̀s principais referências da literatura especializada.

\section{ANÉIS DE CRESCIMENTO}

CONCEITO: Pereira (1933) define os anéis de crescimento como sendo as modificações de aspecto que o conjunto da madeira (lenho) apresenta, refletindo as transições do desenvolvimento da árvore através das épocas de formação. É o acréscimo anual do lenho, subdividido em 2 camadas perfeitamente distintas e correspondentes aos períodos de máximo e mínimo trabalho vegetativo. Mainieri (1958) destaca que os anéis de crescimento são vistos na superfície do topo da madeira quando polida e a FUPEF (1980) afirma que são porções representadas por diferenças marcantes na densidade e na estrutura do lenho inicial e tardio, com áreas distintas. Considerando o crescimento das árvores, Burger \& Richter (1991) explicam que a cada ano um novo anel é acrescentado ao tronco levando a um incremento anual da árvore. De acordo com Kaennel \& Schweingruber (1995) a transição do lenho inicial e 
tardio, de sucessivos anéis de crescimento, resulta das alterações das dimensões das células.

TIPOS: a IAWA considera 2 tipos de anéis de crescimento, sendo (i) anéis de crescimento com limites distintos, com uma transição estrutural abrupta nos seus limites geralmente incluindo mudanças na espessura da parede e/ou no diâmetro radial da fibra ou traqueíde, ou com paredes grossas (lenho tardio) em contraste com os de paredes finas (lenho inicial), diferenças no diâmetro dos vasos dos lenhos tardio e inicial; presença de parênquima marginal; traqueídes vasculares e elementos vasculares muito estreitos e numerosos formando 0 lenho tardio e ausência do lenho inicial; diminuição da freqüência de faixas de parênquima em direção ao lenho tardio resultando em zonas fibrosas distintas. O tipo (ii) é formado pelos anéis de crescimento com limites indistintos ou ausentes, são marcados por mudanças estruturais mais ou menos gradativas.

\section{SISTEMA CONDUTOR}

\section{VASOS}

CONCEITO: segundo Pereira (1933) são tubos que acompanham o eixo do tronco ou dos galhos, em toda a sua extensão, até as folhas. São formados por células curtas ou longas, cilíndricas ou prismáticas, sobrepostas e ligadas pelas suas extremidades, formando um conjunto longitudinal de elementos (Ferreirinha, 1958). Chimelo \& Angyalossy (1983) conceituam vasos como uma série vertical de células coalescentes que forma uma estrutura tubiforme de comprimento indeterminado. Silva (1987) indica que são células individuais interligadas pelas extremidades com a função de condução ascendente de líquidos na árvore (Burger \& Richter, 1991). São células alongadas presentes no xilema em forma de tubo, de comprimento e diâmetro variáveis, com pontoações areoladas nas paredes laterais para com os elementos congêneres, presentes no xilema (Kaennel \& Schweingruber, 1995). 
POROSIDADE- considerando o diâmetro e a distribuição dos vasos, tem-se anéis-porosos (vasos no lenho inicial distintamente maiores do que os do tardio do anel anterior e do mesmo anel de crescimento, formando um anel bem definido, com uma abrupta transição); (ii) anéis-semi-porosos (os vasos no lenho inicial são distintamente maiores do que os do tardio do anel de crescimento anterior, com uma mudança gradativa com vasos mais estreitos no lenho intermediário); (iii) anéis indistintos (os vasos no lenho inicial são pouco espaçados não sendo acentuadamente maiores do que os do tardio do anel anterior e do mesmo anel de crescimento) e (iv) porosidade difusa (os vasos têm mais ou menos o mesmo diâmetro no anel de crescimento sendo que em algumas espécies temperadas os últimos vasos do lenho tardio podem ser consideravelmente menores do que os do inicial do anel seguinte, com diâmetro mais ou menos uniforme na maioria dos anéis de crescimento) (IAWA, 1989).

ARRANJO DOS VASOS- pode ser em (i) faixa tangencial (arranjados perpendicularmente aos raios e formando faixas tangenciais curtas ou longas retas ou sinuosas); (ii) faixa diagonal e/ou radial (arranjados radialmente ou de forma intermediária entre tangencial e radial) e em (iii) padrão dendrítico (arranjados em um padrão ramificado, com regiões distintas, separadas por áreas desprovidas de vasos) (IAWA, 1989).

AGRUPAMENTO DOS VASOS- sendo (i) vasos exclusivamente solitários (90\% ou mais dos vasos são solitários; (ii) $90 \%$ ou mais dos vasos estão completamente circundados por outros elementos; (iii) $90 \%$ ou mais aparecem sem contato com outro vaso; (iv) vasos múltiplos radiais de 4 ou mais; (v) filas radiais de 4 ou mais vasos adjacentes de ocorrência comum; (vi) vaso solitário de contorno angular e (vii) o formato do vaso solitário é angular, visto na seção transversal. 
PLACAS DE PERFURAÇÃO

CONCEITO: Bastos \& Milanez (1936) definem a placa de perfuração como abertura de comunicação entre dois elementos contíguos de um vaso. Ferreirinha (1958) indica que são uma ou mais aberturas das paredes de contato dos elementos vasculares e que estabelecem a sua comunicação vertical. São formadas, segundo Silva (1987) pela dissolução de uma parte ou de toda parede celular na extremidade do elemento de vaso e permitem a circulação de substâncias líquidas (Burger \& Richter, 1991).

TIPOS: define-se como (i) placas de perfuração simples (com uma única abertura circular ou elíptica); (ii) escalariforme (com aberturas alongadas e paralelas separadas por de uma a várias barras, com $\leq 10,10-20,20-40$, e com $\geq 40$ barras); (iii) reticulada (com aberturas pouco espaçadas e separadas por porções de parede mais estreitas ou com ramificação abundante e irregular de porções de parede resultando em uma aparência de retículo ou rede e (iv) foraminada (com aberturas circulares ou elípticas semelhante a uma peneira com porções de parede mais grossas do que no tipo reticulado).

\section{PONTOAÇÕES INTERVASCULARES}

CONCEITO: Pereira (1933) indica que pontoações intervasculares são pequenos furos encontrados nas paredes laterais dos vasos e que representam os orifícios de comunicação por onde circula a seiva de uma para outra. Podem ser simples, semiareoladas ou areoladas (Ferreirinha, 1958). A disposição, aspecto, tamanho e forma são características da madeira de algumas espécies, constituindo importante elemento para a sua identificação (Burger \& Richter 1991).

TIPOS: são (i) escalariformes (alongadas ou lineares arranjadas como série de degraus de escada); (ii) opostas (arranjadas em fileiras horizontais curtas ou longas) e (iii) alternas (arranjadas em fileiras diagonais alternadas, com o contorno angular, com mais de 4 lados). As pontoações intervasculares são 
guarnecidas quando a cavidade e/ou a abertura está total ou parcialmente circundada com projeções da parede secundária (IAWA, 1989).

\section{PONTOAÇÕES RADIOVASCULARES}

CONCEITO: Milanez \& Bastos (1964) definem pontoação radiovascular como o pontuado entre a célula de raio e a de um elemento vascular. São pontoações nas paredes laterais dos vasos que estabelecem contato entre vaso e raio (Burger \& Richter, 1991).

TIPOS: podem ser com bordas (i) distintas (similares à pontoações intervasculares em tamanho e forma através da célula do raio) e (ii) com bordas muito reduzidas a aparentemente simples (IAWA, 1989).

\section{ESPESSAMENTOS HELICOIDAIS}

CONCEITO: Pereira (1933) indica que são reforços em forma de anéis ou de espirais espessadas na parede dos vasos e dão consistência às células ou órgãos em formação. Para Bastos \& Milanez (1936) são cristas helicoidais na face interior da parede secundária e com interesse no diagnóstico. Nas espécies de madeiras de porosidade difusa os vasos com espessamento espiralado distribuem-se ao longo das camadas de crescimento e, nas de porosidade em anel, restringe-se, quase sempre, aos elementos vasculares do lenho tardio (Ferreirinha, 1958).

TIPOS: a IAWA (1989) considera (i) espessamento helicoidal nos elementos vasculares (formam cadeias na face interior da parede do elemento vascular em um padrão helicoidal); (ii) por toda a superfície do elemento vascular; (iii) apenas nas extremidades dos elementos vasculares; e (iv) apenas nos elementos vasculares mais estreitos.

\section{DIÂMETRO TANGENCIAL MÉDIO DOS VASOS}

O diâmetro tangencial médio de $100-200 \mu \mathrm{m}$ é mais comum do que o maior que $200 \mu \mathrm{m}$ ou menor que $50 \mu \mathrm{m}$ (IAWA, 1989). A literatura descreve o 
diâmetro total do vaso, devendo-se excluir a sua parede e medir o diâmetro do lume.

O diâmetro depende das condições de crescimento das árvores com o maior diâmetro no período de maior atividade vegetativa (Pereira, 1933). Segundo Mainieri \& Chimelo (1974) o diâmetro dos vasos varia entre espécies, da medula para a casca e, em um anel de crescimento. Existe um decréscimo da largura do vaso da base ao topo do tronco das árvores (Silva, 1987). TIPOS: podem ser $\leq 50,50-100,100-200$, e $\geq 200 \mu \mathrm{m}$ (IAWA, 1989).

\section{FREQÜÊNCIA DOS VASOS}

A freqüência dos vasos $\left(\mathrm{n}^{\circ} / \mathrm{mm}^{2}\right)$ não é considerada para espécies de madeiras de anéis porosos e de vasos com extensões definidas com traqueídes vasculares/vasicêntricas (IAWA, 1989). A freqüência é de interesse relativo, muito variável entre as diferentes espécies e notada entre árvores de mesma espécie. Em um anel de crescimento anual o número de vasos é maior em uma das bordas e, apesar das variações, a freqüência média é um índice relacionado com algumas propriedades físicas da madeira (Pereira, 1933). A freqüência de vasos permite classificar as espécies de madeiras com poros raros, numerosos e muito numerosos (Ferreirinha, 1958).

TIPOS: classificam-se em espécies de madeiras com $\leq 5,5-20,20-40,40-100$ e $\geq 100$ vasos $/ \mathrm{mm}^{2}$ (IAWA, 1989).

\section{COMPRIMENTO DO VASO}

O comprimento médio do elemento de vaso é classificado em $\leq 350$, 350800 e $\geq 800 \mu \mathrm{m}$ (IAWA, 1989).

\section{TILOSES}

CONCEITO: Bastos \& Milanez (1936) definem tilose como a proliferação ou a hipertrofia do protoplasma das células parenquimáticas penetrando através de um par de pontoações na cavidade de um vaso ou de uma traqueíde adjacente. Surge, principalmente, nos vasos do cerne, freqüente nas madeiras tropicais 
sendo que a proliferação de células vizinhas, através das pontoações dos vasos, é provocada pela diferença de pressão osmótica do vaso (fisiologicamente inativo) e as células vivas circundantes (Ferreirinha, 1958). É formada na transição alburno/cerne e pode ser resultado de injúria (Silva, 1987), com conteúdo de considerável importância para a anatomia, identificação e propriedades tecnológicas da madeira (Burger \& Richter, 1991).

TIPOS: pode ser de ocorrência comum quando cresce a partir de uma célula de raio ou de parênquima axial adjacente através da pontoação de uma parede de vaso bloqueando parcial ou totalmente o seu lume sendo esclerosada quando o tilo tem sua parede muito espessa e lignificada. Algumas espécies de madeiras podem ter tiloses e depósitos de gomas, incluindo compostos químicos com variação de cor (branco, amarelo, vermelho, marrom, preto, etc) (IAWA, 1989).

\section{GOMAS}

CONCEITO: os depósitos gomosos são freqüentes principalmente em madeiras densas e coradas, distribuindo-se nos vasos e formando tampões na área das perfurações ou preenchendo quase completamente a sua cavidade e contribuindo para o aumento da densidade da madeira (Ferreirinha, 1958). Pode ser designado como gomo-resina tendo importância para na anatomia, identificação e propriedades tecnológicas da madeira (Burger \& Richter, 1991).

\section{SISTEMA DE CONDUÇÃO E SUSTENTAÇÃO}

\section{TRAQUEÍDES}

CONCEITO: são estruturas presentes em espécies de madeiras não-porosas, sem células vasculares típicas e compostas de elementos traqueários fechados e de parênquima.

Mainieri \& Chimelo (1974) definem as traqueídes como células longas, estreitas e com extremidades fechadas semelhantes a tubos, com parede fina no lenho inicial e espessa no lenho tardio. Suas funções se equiparam à das fibras e às dos elementos vasculares (Mainieri, 1983), sendo abundantes nas 
coníferas, com cerca de 90\% (Silva, 1987) e com pontoações areoladas para os elementos congêneres (Kaennel \& Schweingruber, 1995).

TIPOS: (i) traqueídes vasculares (células imperfuradas que se parecem com os elementos vasculares em tamanho, forma, pontoação e ornamentação da parede); e (ii) traqueídes vasicêntricas (células imperfuradas com pontoações areoladas e numerosas em sua parede radial e tangencial e presentes ao redor dos vasos (IAWA, 1989).

\section{SISTEMA DE SUSTENTAÇÃO}

\section{FIBRAS}

CONCEITO: o tecido fibroso ou de suporte é composto de elementos fusiformes, de comprimento variável, dispostos no sentido paralelo ao tronco da árvore (Pereira, 1933), com paredes espessas e pontoações simples, imperfuradas e de pequeno diâmetro (Ferreirinha, 1958). Milanez \& Bastos (1964) afirmam ser células longas e estreitas do lenho, não vascular ou parenquimatosa, sendo fechadas nas extremidades e pontiagudas (Silva, 1987) e peculiares ì angiospermas, com a maior porcentagem de seu lenho (Burger \& Richter, 1991). TIPOS: (i) fibras libriformes (com pontoações areoladas simples, pequenas com o lume < $3 \mu \mathrm{m}$ de diâmetro; (ii) fibrotraqueídes (com pontoações areoladas distintas com o lume $>3 \mu \mathrm{m}$ de diâmetro e (iii) fibras com pontoações comuns (IAWA, 1989).

FIBRA SEPTADA

CONCEITO: possui o lume dividido por delgadas paredes transversais em pequenas câmaras (Mainieri \& Chimelo, 1974) e (Burger \& Richter, 1991).

TIPOS: fibras septadas (fibras com paredes finas, sem pontoações) (IAWA, 1989).

\section{ESPESSURA DA PAREDE DAS FIBRAS}

CONCEITO: segundo Ferreirinha (1958) a espessura da parede das fibras varia dentro da espécie ou dentro da amostra e nas camadas de crescimento sendo 
no lenho tardio marcadamente diferente do que no inicial (Ferreirinha, 1958). Para Mainieri \& Chimelo (1974) as fibras variam em comprimento, largura e espessura da parede, entre as espécies e em uma mesma árvore ao longo do seu caule e da medula para a casca.

TIPOS: podem ser (i) de paredes muito finas (o lume da fibra é 3 a mais $x$ mais largo do que o dobro da espessura da parede); (ii) finas a grossas (o lume da fibra é menos de 3 x o dobro da espessura da parede e distintamente abertas) e (iii) muito grossas (o lume da fibra é completamente fechado) (IAWA, 1989).

\section{COMPRIMENTO MÉDIO DAS FIBRAS}

CONCEITO: para Silva (1987) as fibras xilemáticas são, geralmente, mais longas do que as iniciais fusiformes cambiais das quais elas originam, variando entre e dentro de espécies e ao longo da árvore.

TIPOS: classificam-se em $\leq 900,900-1600$ e $\geq 1600 \mu \mathrm{m}$ (IAWA, 1989).

\section{SISTEMA DE ARMAZENAMENTO}

\section{PARÊNQUIMA}

CONCEITO: tecido conjuntivo, e, portanto, de menor resistência na madeira (Pereira, 1933) distinguível por formar manchas mais claras espalhadas na massa lenhosa cuja distribuição tem muita importância na identificação da espécie (Ferreirinha, 1958). É um tecido com células orientadas no sentido do eixo maior que exerce a função de preenchimento e de armazenamento de substâncias nutritivas para o vegetal (Mainieri \& Chimelo, 1974). As células têm paredes finas derivadas das iniciais fusiformes do câmbio vascular, não lignificadas, geralmente com pontoações simples, relacionadas primariamente com o armazenamento e distribuição dos carboidratos (Silva, 1987). São células vivas (funcionais) no alburno e geralmente retangulares (Kaennel \& Schweingruber, 1995).

TIPOS: estão presentes no lenho da árvore sob diferentes formas e quantidades, sendo classificados (IAWA, 1989), como parênquima axial 
apotraqueal (não associado ao vaso) do tipo (i) difuso (as filas únicas de parênquima ou pares de filas estão distribuídas irregularmente entre os elementos fibrosos da madeira); (ii) difuso em agregados (as filas de parênquima estão agrupadas em linhas curtas descontínuas tangenciais ou oblíquas); e parênquima axial paratraqueal (associado com os vasos ou com traqueídes vasculares) do tipo (i) escasso (células ocasionais de parênquima associadas com os vasos ou uma bainha incompleta de parênquima ao redor dos vasos); (ii) vasicêntrico (células de parênquima formam uma bainha completa circular a oval ao redor de um vaso solitário ou múltiplo); (iii) aliforme (parênquima ao redor do vaso tem extensões laterais), sendo aliforme losangular (extensões laterais formam um contorno em forma de losango) e aliforme linear (extensões laterais são alongadas e estreitas) podendo ser confluente (parênquima ao redor de um ou mais vasos formam faixas irregulares) em paratraqueal unilateral (forma uma cobertura semicircular em um dos lados do vaso estendendo-se tangencial ou obliquamente em padrão aliforme, confluente ou em faixas).

Citam-se o parênquima em faixas (mais de três células de largura), em faixas ou linhas (com até três células de largura), reticulado (linhas contínuas tangenciais com aproximadamente a mesma largura dos raios, regularmente espaçadas, formando uma rede), escalariforme (linhas finas ou faixas fracamente espaçadas, arranjadas horizontalmente ou em arcos, mais estreitas que os raios com a aparência de escada cuja distância é maior do que a das faixas de parênquima), faixas marginais (faixas de parênquima formam camadas mais ou menos contínuas, de largura variável nas margens do anel de crescimento).

RAIO

CONCEITO: tecido parenquimático formado por agrupamentos celulares que se dispõe horizontalmente, convergindo para a medula (Pereira, 1933). Promove uma perfeita comunicação entre as partes mais internas do vegetal e o meio 
exterior conduzindo a seiva elaborada para a parte funcional do caule (alburno), e armazenando substâncias nutritivas para a planta (Mainieri \& Chimelo, 1974). $\mathrm{Na}$ seção transversal são como numerosas linhas retilíneas, aproximadas, geralmente mais claras, na seção angencial de forma lenticular e, na seção radial são como linhas ou fitas horizontais formando, ocasionalmente, configurações distintas a olho nu (Mainieri, 1983).

TIPOS: agregado de células, em forma de fita, formado pelo câmbio e estendendo-se radialmente no lenho e no líber classificado, em relação àlargura como exclusivamente unisseriados $(1-3,4-10,>10$ células de largura) e raios com porções uni e multisseriadas. Os raios agregados, são raios individuais intimamente associados que macroscopicamente aparentam um único grande raio; os raios individuais são separados por elementos axiais. Em relação à altura podem ser classificados em 2 tamanhos distintos vistos na seção tangencial. Em relação à composição celular na seção radial, são classificados como (i) procumbente (célula de raio com a sua maior dimensão radial); (ii) quadrado (célula aproximadamente quadrada) e (iii) vertical (célula com a sua maior dimensão axial). Os raios podem ser compostos (i) por todas as células procumbentes; (ii) todas verticais e ou quadradas; (iii) procumbentes com uma fileira marginal de células verticais e ou quadradas; (iv) procumbentes com 2-4 fileiras marginais de células verticais e ou quadradas; (v) procumbentes com mais de 4 fileiras marginais de células verticais e ou quadrada; e (vi) procumbentes, quadradas e verticais misturadas pelo raio. As células da bainha estão localizadas ao longo das partes mais largas dos raios (mais que trisseriado) na seção tangencial e são maiores (geralmente mais altas do que largas) do que as células centrais do raio. Células de "telhado", são um tipo especial de células de raio aparentemente verticais que ocorrem nas séries horizontais intermediárias geralmente interpassadas entre as células procumbentes. As células perfuradas do raio são de mesmas dimensões ou maiores do que as adjacentes com perfurações no lado das paredes que conectam dois vasos em cada lado do raio. As células disjuntivas nas paredes 
do parênquima radial são células parcialmente desunidas mas com contatos mantidos pelo sistema tubular ou complexo da parede. A freqüência de raios é classificada em $\leq 4,4-12$ e $\geq 12$ raios/mm (IAWA, 1989).

\section{ESTRUTURAS ESTRATIFICADAS}

CONCEITO: caráter de especialização em certas famílias de dicotiledôneas, mais freqüente em espécies tropicais (Ferreirinha, 1958). Verificada nos elementos prosenquimatosos verticais ou nos raios e, em casos de maior regularidade, estende-se a todos os elementos. São definidas (Burger \& Richter, 1991) como elementos axiais organizados formando faixas horizontais regulares ou estratos, com efeito visual normalmente evidenciado sob macroscopia e principalmente no corte longitudinal tangencial.

TIPOS: células de raios, parênquima axial e elementos vasculares arranjados em fileiras (séries horizontais) vistas na seção tangencial.

\section{CÉLULAS OLEÍFERAS E MUCILAGINOSAS}

CONCEITO: células especializadas dos raios e do parênquima axial tipicamente arredondadas que contém óleo ou mucilagem (Ferreirinha, 1958). São características das madeiras de certas famílias e se dispersam no lenho principalmente nos parênquimas axial e radial. Além de aumentar apreciavelmente o peso da madeira permite, em certos casos, o aproveitamento industrial de certos óleos essenciais para fins medicinais e de perfumaria. Por outro lado, as substâncias das células oleíferas podem comprometer a utilização da madeira na fabricação de polpa e papel, dificultar a aplicação de tintas e revestimentos e a colagem da madeira.

TIPOS: células oleíferas e mucilaginosas são idioblastos parenquimatosos preenchidos com óleo e mucilagem (IAWA, 1989).

CANAIS INTERCELULARES

CONCEITO: são condutos ou espaços intercelulares servindo geralmente como depósito de resinas ou gomas (Mainieri, 1983) com comprimento indeterminado, 
sem paredes próprias e revestidos por células parenquimáticas especiais (Burger \& Richter, 1991).

TIPOS: ducto tubular intercelular orientado axial ou radialmente rodeado por um epitélio contendo produtos secundários da planta, tais como resinas, gomas, etc., secretados pelas células epiteliais. Ocorrem em longas linhas tangenciais com mais de 5 em uma linha tangencial em distribuição difusa aleatória e solitários podendo estar presentes nos raios. Podem ser formados em resposta a injúrias, em faixas tangenciais de contorno irregular e pouco espaçados.

\section{TUBOS}

CONCEITO: são condutos inclusos nos raios comunicando-se com tubos verticais do córtex e/ou da medula (Bastos \& Milanez, 1936), são longos, não pontoados, com substância amarelada ou avermelhada quando fresca e vermelho-escuro após endurecer (Ferreirinha, 1958).

TIPOS: células ou série de células de comprimento indeterminado, estendendose radial ou verticalmente entre as fibras; podem ser (i) laticíferos (contêm látex incolor ou amarelo brilhante ao marrom) e (ii) taniníferos (contêm taninos, que são marrom-avermelhado) (IAWA, 1989).

FLOEMA INCLUSO

CONCEITO: resulta de variações da atividade cambial a partir do crescimento diferencial do câmbio regularmente formado ou de camadas anormais de câmbio (Ferreirinha, 1958), formando manchas ou camadas de floema incluídas no xilema de certas dicotiledôneas (Mainieri, 1983).

TIPOS: dois tipos de floema incluso, (i) concêntrico (filas de floema em faixas tangenciais alternadas com zonas de xilema e/ou tecido conjuntivo) e (ii) difuso (filas de floema isoladas espalhadas rodeadas por parênquima ou elementos traqueais imperfurados) (IAWA, 1989). 


\section{CRISTAIS}

CONCEITO: aparecem com freqüência nos tecidos lenhosos, medindo até 30 $\mu \mathrm{m}$, localizados no tecido conjuntivo (Pereira, 1933); os mais freqüentes são os de oxalato de cálcio em célula fisiologicamente ativa e parecem estar incluídos freqüentemente em vacúolo ligado à parede celular (Ferreirinha, 1958). Os cristais encontram-se principalmente em células parenquimáticas e em alguns casos possui valor diagnóstico (Burger \& Richter, 1991).

TIPOS: classificam-se em (i) cristais prismáticos (cristais solitários romboidais ou octaédricos compostos de oxalato de cálcio e evidenciados sob luz polarizada, em células de raio, parênquima axial e fibras), (ii) drusas (cristais compostos de forma esférica com componentes projetando para a superfície com aparência de estrela, em células do parênquima radial, axial e fibras), (iii) ráfide (feixe de longos cristais em forma de agulhas), (iv) cristais aciculares (pequenos cristais em forma de agulhas não ocorrendo em feixes), (v) estilóides (cristais grandes com finais quadrados ou pontudos), (vi) cristais de areia (massa granular composta de muitos cristais pequenos) e (vii) cristais de outras formas (na maioria pequenos e inclui todos os outros tipos de cristais) (IAWA, 1989).

SÍLICA

CONCEITO: geralmente sob a forma de corpúsculos silicosos menores do que o lume das células (Ferreirinha, 1958), com química e grau de dureza semelhantes aos do diamante, no interior das células em forma de partículas ou grãos nos raios e parênquima axial e raros nos demais elementos verticais (Burger \& Richter, 1991).

TIPOS: são partículas esféricas ou de forma irregular, compostas de dióxido de sílica, localizada nas células do raio, parênquima axial, ou fibras; a sílica vítrea cobre a parede ou preenche completamente o lume da célula (IAWA, 1989). 


\section{MATERIAL}

\subsection{Locais}

Os materiais botânicos e as amostras do lenho das espécies arbóreas foram coletados nos seguintes locais:

-Estação Ecológica de Ibicatu: Unidade de Conservação administrada pelo Instituto Florestal situada no Município de Piracicaba (SP; distante $35 \mathrm{~km}$ da cidade de Piracicaba) entre as coordenadas geográficas de $22^{\circ} 46^{\prime}$ Latitude Sul e $47^{\circ} 43^{\prime}$ longitude Oeste (Custódio Filho et al., 1994), cobrindo uma área de 76,4 ha, contornada por culturas agrícolas e pastagens.

-Reserva Estadual de Porto Ferreira: Reserva Estadual localizada no Município de Porto Ferreira - SP (distante $135 \mathrm{~km}$ da cidade de Piracicaba) entre as coordenadas geográficas de $21^{\circ} 49^{\prime}$ Latitude Sul e $47^{\circ} 25^{\prime}$ ' Longitude Oeste e altitude variando de 540 a 608 m (Bertoni, 1984). A Reserva Estadual pertence ao Instituto Florestal e apresenta uma área total de 611,55 ha, limitando-se ao norte com a rodovia SP-215, ao sul com o rio Moji Guaçu, ao leste com o Ribeirão dos Patos e ao oeste com o Córrego da Água Parada.

-Arboreto Experimental da Duratex S.A.: Arboreto localizado no Município de Agudos - SP (distante $180 \mathrm{~km}$ da cidade de Piracicaba) nas coordenadas geográficas de $22^{\circ} 25^{\prime}$ de Latitude Sul e $48^{\circ} 50^{\prime}$ de Longitude Oeste e altitude de $600 \mathrm{~m}$ em relevo levemente ondulado. 
-Estação Experimental de Tupi: Estação Experimental administrada pelo Instituto Florestal situada no Município de Piracicaba - SP (distante $15 \mathrm{~km}$ da cidade de Piracicaba) entre as coordenadas geográficas de $22^{\circ} 43^{\prime} 21^{\prime \prime}$ de Latitude Sul e $47^{\circ} 31^{\prime} 47^{\prime \prime}$ de Longitude Oeste, altitude média de $515 \mathrm{~m}$ e com uma área total de aproximadamente 198 ha (Mariano et al., 1998).

-Estação Experimental de Santa Rita do Passa Quatro: Estação Experimental sob a coordenação da Divisão de Florestas e Estações Experimentais do Instituto Florestal situada em Santa Rita do Passa Quatro - SP sob as coordenadas geográficas de $21^{\circ} 40^{\prime}$ de Latitude Sul e $47^{\circ} 30^{\prime}$ de Longitude Oeste e altitude média de 715 m e com uma área total de 96,3 ha (Gurgel Filho, 1975).

-Sítio São Luiz: área localizada no município de Jundiaí - SP, propriedade de Santa Angela Urbanização e Construção LTDA., com uma área de aproximadamente 43 ha.

-Reserva Florestal Mata de Santa Genebra: Reserva Florestal administrada pela Fundação José Pedro de Oliveira, está localizada entre os municípios de Campinas e Piracicaba - SP, entre as coordenadas geográficas de 220 44'45" de

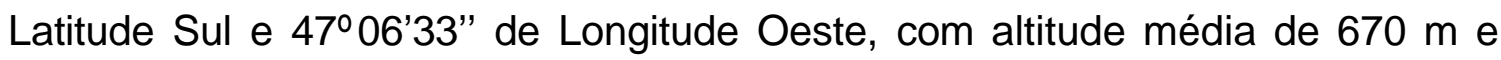
ocupa uma área de 251,77 ha. 


\subsection{Espécies selecionadas}

Tabela 1. Espécies coletadas na área do Sítio São Luiz.

\begin{tabular}{|c|c|c|}
\hline FAMÍLIA & ESPÉCIE & NOME COMUM \\
\hline Anacardiaceae & Astronium graveolens Jacq. & Guaritá \\
\hline Anacardiaceae & Schinus terebinthifolius Raddi & Aroeira-vermelha \\
\hline Apocynaceae & Aspidosperma cylindrocarpon M. Arg. & Peroba-poca \\
\hline Apocynaceae & Aspidosperma ramiflorum M. Arg. & Guatambu \\
\hline Asteraceae & Gochnatia polymorpha (Less.) Cabr. & Cambará \\
\hline Bignoniaceae & Tabebuia chrysotricha (Mart. ex DC.)Standl. & Ipê-amarelo \\
\hline Bombacaceae & Bombax grandiflorum Cav. & Embiruçu \\
\hline Bombacaceae & Chorisia speciosa St. Hil. & Paineira \\
\hline Boraginaceae & Cordia sellowiana Cham. & Chá-de-bugre \\
\hline Combretaceae & Terminalia brasiliensis Camb. & Capitão-do-campo \\
\hline Euphorbiaceae & Alchornea sidifolia Muell. Arg. & Tanheiro \\
\hline Euphorbiaceae & Croton sp. & Capixingui \\
\hline Lauraceae & Ocotea puberula (Reich.) Nees & Guaicá \\
\hline Leg.-Caesalpiniaceae & Bauhinia forficata Link & Unha-de-vaca \\
\hline Leg.-Caesalpiniaceae & Copaifera langsdorfii Desf. & Copaífera \\
\hline Leg.-Caesalpiniaceae & Hymenaea courbaril L. & Jatobá \\
\hline Leg.-Caesalpiniaceae & Schizolobium parahyba (Vell.) Blake & Guapuruvu \\
\hline Leg.-Fabaceae & Machaerium aculeatum Raddi & Bico-de-pato \\
\hline Leg.-Fabaceae & Machaerium villosum Vog. & Jacarandá \\
\hline Leg.-Mimosaceae & Piptadenia gonoacantha (Mart.) Macbr. & Pau-jacaré \\
\hline Melastomataceae & Tibouchina granulosa Cogn. & Quaresmeira \\
\hline Meliaceae & Cabralea canjerana (Vell.) Mart. & Canjarana \\
\hline Myrsinaceae & Rapanea umbellata (Mart.). Mez. & Capororoca \\
\hline Myrtaceae & Eugenia uniflora Linnaeus & Pitangueira \\
\hline Rutaceae & Zanthoxylum rhoifolium Lam. & Mamica-de-porca \\
\hline Sterculiaceae & Guazuma ulmifolia Lam. & Mutambo \\
\hline Ulmaceae & Trema micrantha (L.) Blume & Candiúba \\
\hline
\end{tabular}


Tabela 2. Espécies coletadas na Mata de Santa Genebra.

\begin{tabular}{ccc}
\hline FAMÍLIA & ESPÉCIE & NOME COMUM \\
Euphorbiaceae & Pachystroma ilicifolium Muell. Arg. & Canxim \\
Leg.-Papilionoideae & Centrolobium sp. & Araribá \\
\hline
\end{tabular}

Tabela 3. Espécies coletadas na Estação Ecológica de Ibicatu.

\begin{tabular}{ccc}
\hline FAMÍLIA & ESPÉCIE & NOME COMUM \\
\hline Apocynaceae & Aspidosperma polyneuron M Arg. & Peroba-rosa \\
Euphorbiaceae & Securinega guarayuva Kuhlm. & Guaraiúva \\
\hline
\end{tabular}

Tabela 4. Espécies coletadas na Estação Experimental de Tupi.

\begin{tabular}{ccc}
\hline FAMÍLIA & ESPÉCIE & NOME COMUM \\
\hline Lecythidaceae & Cariniana estrellensis (Raddi) O. Ktze. & Jequitibá-branco \\
Leg.-Caesalpiniaceae & Caesalpinia ferrea Mart. & Pau-ferro \\
Rutaceae & Esenbeckia leiocarpa Engl. & Guarantã \\
\hline
\end{tabular}

Tabela 5. Espécies coletadas no Arboreto Experimental da Duratex S.A.

\begin{tabular}{ccc}
\hline FAMÍLIA & ESPÉCIE & NOMECOMUM \\
\hline Leg.-Papilionoideae & Dipteryx sp. & Cumaru \\
Leg.-Mimosaceae & Piptadenia macrocarpa Benth. & Angico-preto \\
\hline
\end{tabular}

Tabela 6. Espécies coletadas na Reserva Estadual de Porto Ferreira.

\begin{tabular}{ccc}
\hline FAMÍLIA & ESPÉCIE & NOMECOMUM \\
\hline Erythroxylaceae & Erythroxylum sp. & Fruta-de-pomba \\
Lecythidaceae & Cariniana legallis (Mart.) O.Ktze & Jequitibá-rosa \\
\hline
\end{tabular}


Tabela 7. Espécies coletadas na Estação Experimental de Santa Rita do Passa Quatro.

\begin{tabular}{ccc}
\hline FAMÍL IA & ESPÉCIE & NOME COMUM \\
\hline Lauraceae & Ocotea porosa (Nus \& Mart.) Barroso & Imbuia \\
Leg.-Caesalpiniaceae & Cassia ferruginea Schrad. & Canafístula \\
Leg.-Papilionoideae & Platycyamus regnelli Benth. & Pau-pereira \\
\hline
\end{tabular}

\subsection{Principais usos das espécies selecionadas}

AROEIRA-VERMELHA - Schinus terebinthifolius

Possui madeira de boa qualidade para a construção de moirões, produção de lenha e carvão, além de ser uma espécie ornamental (Lorenzi, 1992).

CAMBARÁ - Gochnatia polymorpha

Os extratos das folhas dessa espécie são usados na medicina, por possuírem atividade anti-inflamatória (Moreira et al., 2000).

PAINEIRA - Chorisia speciosa

Possui madeira de boa qualidade para a construção de canoas, caixotarias e para a produção de pasta celulósica, além de ser uma espécie ornamental (Lorenzi, 1992).

TANHEIRO - Alchornea sidifolia

Possui madeira leve adequada para ser empregada em caixotaria e carpintaria (Mainieri, 1958). 


\section{UNHA-DE-VACA - Bauhinia forficata}

Sua madeira é moderadamente pesada podendo ser empregeda para caixotaria, e obras leves (Lorenzi, 1992). As folhas dessa espécie, quando colocadas em infusão, possuem atividade hipoglicêmica (Luján \& Barboza, 1999).

\section{COPAÍBA - Copaifera langsdorfii}

Sua madeira é de boa qualidade para construção civil e da sua casca é extraído um corante amarelo utilizado em tinturaria (Almeida et al., 1998). Como medicinal ela oferece proteção gástrica devido ao óleo-resina (Paiva et al., 1998).

\section{JACARANDÁ-PAULISTA - Machaerium villosum}

Possui uma madeira pesada com aparência agradável, o que a torna adequada para ser empregada na fabricação de tacos, vigas, dormentes e instrumentos musicais (Mainieri \& Chimelo, 1989).

\section{PAU-JACARÉ - Piptadenia gonoacantha}

Possui madeira moderadamente pesada, de boa qualidade para acabamentos internos, construção de brinquedos e vigamentos (Mainieri \& Chimelo, 1989).

\section{GUAPURUVU - Schizolobium parahyba}

Possui madeira muito leve que é usada em miolos de painéis e portas, fabricação de brinquedos e embalagens (Mainieri \& Chimelo, 1989).

\section{QUARESMEIRA - Tibouchina granulosa}

Possui madeira de boa qualidade para uso interno e construção de brinquedos e caixotaria, além de ser uma árvore ornamental (Lorenzi, 1992). 


\section{CARAPOROCA - Rapanea umbellata}

Sua madeira possui boa qualidade para utilização na construção civil em uso interno, fabricação de móveis, produção de lenha e carvão. Sua casca possui propriedades medicinais sendo uma árvore ornamental (Lorenzi, 1998).

\section{PITANGUEIRA - Eugenia uniflora}

Sua madeira é moderadamente pesada, sendo empregada para confecção de cabos de ferramentas e instrumentos agrï colas (Lorenzi, 1992). O extrato da folha dessa espécie possui atividade antihipertensiva, pois possui agentes diuréticos (Amat et al., 1999).

CANXIM - Pachystroma ilicifolium

Madeira dura, sendo de boa qualidade para a construção de vigas, ripas, rodapés e tábuas (Mainieri \& Chimelo, 1989).

ARARIBÁ - Centrolobium sp.

Possui madeira moderadamente pesada sendo adequada para construção naval e civil. Suas folhas e cascas possuem propriedades medicinais no tratamento de diarréia, devido àpresença de taninos (Almeida et al., 1998).

\section{PEROBA-ROSA - Aspidosperma polyneuron}

Possui madeira de dureza média sendo utilizada para a construção de portas, tacos para assoalhos, degraus e móveis pesados (Mainieri \& Chimelo, 1989).

\section{GUARAIÚVA - Securinega guarayuva}

Possui madeira moderadamente pesada usada para caixotaria, lápis, produção de lenha e carvão, além de ser uma árvore ornamental (Almeida et al., 1998). 
JEQUITIBÁ-BRANCO - Cariniana estrellensis

Sua madeira é moderadamente leve, usada na construção civil em obras internas e na fabricação de papel. Sua casca contém substâncias adstringentes, com propriedades medicinais, no tratamento de diarréia e anginas (Almeida et al., 1998).

\section{PAU-FERRO - Caesalpinia ferrea}

Sua madeira é muito pesada podendo ser empregada para construção civil em obras externas e para marcenaria em geral (Lorenzi, 1992). Ë uma espécie com usos medicinais, sendo utilizada no tratamento de tuberculose (Storey \& Salem, 1997), o extrato da casca possui substância com ação antiinflamatória e analgésica (Carvalho et al., 1996).

GUARANTÃ - Esenbeckia leiocarpa

Possui madeira muito pesada, utilizada na construção civil, fabricação de assoalhos e carrocerias (Mainieri \& Chimelo, 1989).

CUMARU - Dipteryx sp.

Possui madeira adequada para a construção de tabuados e caixas. De seus frutos é extraída a substância rutina que causa contrações uterinas e sua casca possui substâncias adstringentes que atuam em hemoptises (Almeida et al., 1998).

\section{ANGICO-PRETO - Piptadenia macrocarpa}

Sua madeira é dura e pesada, utilizada na fabricação de tabuados, vigamentos e móveis. A infusão de suas folhas em xarope é hemostática, depurativa e adstringente (Burle, 1988). 
FRUTA-DE-POMBA - Erythroxylum sp.

As madeiras de espécies desse gênero são pesadas, usadas na construção civil na fabricação de esquadrias (Lorenzi, 1998).

JEQUITIBÁ-ROSA - Cariniana legallis

Possui madeira leve que pode ser empregada na fabricação de móveis, acabamentos internos e brinquedos (Mainieri \& Chimelo, 1989).

IMBUIA - Ocotea porosa

Sua madeira é moderadamente pesada, sendo utilizada na fabricação de móveis, tábuas para assoalhos, vigas e instrumentos musicais (Mainieri \& Chimelo, 1989).

CANAFÍSTULA - Cassia ferruginea

Sua madeira é utilizada na fabricação de vigas, sua casca possui propriedades para utilização em curtumes, além de ser uma árvore ornamental (Almeida et al., 1998).

PAU-PEREIRA - Platycyamus regnelli

Sua madeira é utilizada para na construção civil e sua raiz e casca possuem propriedades medicinais, contendo substâncias febrífugas (Almeida et al., 1998).

CAPITÃO-DO-CAMPO - Terminalia brasiliensis

A madeira desse gênero possui propriedades mecânicas médias, usada para acabamentos internos (Mainieri \& Chimelo, 1989). 
JATOBÁ - Hymenaea courbaril

Sua madeira é pesada sendo adequada na construção civil para a confecção de vigas, caibros, para acabamentos internos, tacos para assoalho e móveis (Lorenzi, 1992). É uma espécie utilizada no tratamento médico da tuberculose (Storey \& Salem, 1997).

IPÊ-AMARELO - Tabebuia chrysotricha

Sua madeira é moderadamenta pesada e utilizada em obras externas como postes, peças para pontes e em obras internas na construção civil como tacos para assoalho e rodapés (Lorenzi, 1992). De acordo com Grazziotin et al. (1992), o extrato da madeira dessa espécie possui potencial para ser usado como analgésico.

\section{GUATAMBU - Aspidosperma ramiflorum}

A madeira tem propriedades mecânicas médias a altas e pode ser utilizada para a fabricação de instrumentos musicais, cabos de ferramentas e forma para calçados (Mainieri \& Chimelo, 1989).

\section{GUARITÁ - Astronium graveolens}

A madeira dessa espécie possui propriedades mecânicas médias a altas e pode ser utilizada para acabamentos internos (Mainieri \& Chimelo, 1989).

\section{CHÁ-DE-BUGRE - Cordia sellowiana}

Espécie com madeira leve, utilizada para obras internas, marcenaria e carpintaria (Lorenzi, 1992).

\section{EMBIRUÇU - Bombax grandiflorum}

A madeira dessa espécie é leve, podendo ser utilizada para caixotaria e miolo de compensados (Lorenzi, 1992). 


\section{PEROBA-POCA - Aspidosperma cylindrocarpon}

A madeira dessa espécie pode ser utilizada para a construção civil, carpintaria, tacos e carroceria (Lorenzi, 1992).

CANJARANA - Cabralea canjerana

Possui madeira moderadamente pesada sendo indicada para a construção de estruturas de móveis, obras de esculturas e na construção civil para rodapés, molduras, ripas e esqyuadrias (Lorenzi, 1992). Terpenóides existentes nessa espécie possuem ação tripanocida, matando espécies do protozoário do gênero Trypanosoma sp. (Monteiro, 1997).

BICO-DE-PATO - Machaerium aculeatum

Essa espécie possui madeira moderadamente pesada, que pode ser empregada na construção civil e para a confecção de caixotaria e objetos leves (Lorenzi, 1992).

GUIACÁ - Ocotea puberula

Sua madeiea é leve podendo ser empregada na construção civil em obras internas como forros e para a confecção de carrocerias, em marcenaria, móveis simples e caixotaria (Lorenzi, 1992). Essa espécie possui em suas estruturas alcalóides aporfínicos (Werle, 1987).

CAPIXINGUI - Croton sp.

Extratos da casca de espécies desse gênero possuem atividade antimicrobiana e podem ser usadas no tratamento de reumatismo e câncer e compostos analgésicos (Peres et al., 1997, 1998). 
MAMICA-DE-PORCA - Zanthoxylum rhoifolium

Sua madeira é leve e flexível sendo própria para a construção civil, marcenaria e carpintaria (Lorenzi, 1992). Extratos da casca dessa espécie possuem atividade antibacteriana e antitumoral (Moura et al., 1998).

MUTAMBO - Guazuma ulmifolia

Sua madeira é leve podendo ser usada na confecção de tonéis, construções internas, caixotaria e pasta celulósica (Lorenzi, 1992). Extratos da folha dessa espécie possuem efeitos anti hiperglicêmicos, para serem usados em casos de diabetes mellitus (Aguilara et al., 1998).

\section{CANDIÚBA - Trema micrantha}

Possui madeira leve que pode ser usada na confecção de tabuado (lorenzi, 1992). Extratos das folhas dessa espécie possuem atividade analgésica e antiinflamatória em ratos (Babera et al., 1992). Ribeiro \& Luz (1973) e Andrade et al. (1978), indicam que a espécie fornece excelente matéria-prima para a produção de celulose para papel. 


\section{MÉTODOS}

\subsection{Coleta do material botânico e das amostras de madeira}

\subsubsection{Material botânico}

De acordo com ${ }^{2}$ Roderjan (1987), citado por Pinheiro \& Almeida (2000), os métodos e equipamentos para a coleta de material botânico podem variar de acordo com (i) o tipo e quantidade do material a ser coletado, (ii) com a facilidade de acesso ao local de coleta (floresta, cidade) e (iii) com a possibilidade de coleta do material (árvores altas, baixas e arbustos).

Foi utilizado um podão de vara para a coleta de ramos floridos das espécies que receberam uma etiqueta e identificados com um número, também, anotado no caderno de coleta. O material foi prensado em campo em uma prensa composta de madeira, couro, lona e papelão (Pinheiro \& Almeida, 2000). Cada material botânico foi colocado em uma folha de jornal dobrada e intercalada com um conjunto de papelão permitindo a circulação do ar, reduzindo a umidade e evitando o ataque de fungos. No laboratório, as prensas foram colocadas em estufa para a secagem rápida dos materiais botânicos.

\subsubsection{Amostras de madeira}

Para os estudos de anatomia do lenho das espécies arbóreas pode-se (i) abater a árvore (método destrutivo) ou (ii) retirar amostras em forma de cunha com moto-serra ou outro equipamento (método não destrutivo), com restrições para espécies de madeira de elevada densidade e dureza. Shimoya \& Ramalho (1969) citam a sonda de Pressler para a coleta de amostras de madeira

\footnotetext{
${ }^{2}$ Roderjan, C., 1987
} 
(segmento de material lenhoso de pequeno diâmetro), não suficientes para o estudo anatômico detalhado principalmente quando há necessidade da confecção de lâminas histológicas. Wher e Tomazello Filho (2000) para analisar a anatomia do lenho e dos anéis de crescimento de Araucaria angustifolia utilizaram 2 procedimentos para a coleta das amostras, o destrutivo, pelo corte de uma árvore (para retirada de um disco de madeira) e o não destrutivo, com a sonda de Pressler. Lemos et al. (2000) propõem o uso de um extrator motorizado para a retirada de amostras de lenho do tronco de árvores de Pinus spp., como um eficiente método não destrutivo.

No presente trabalho foi utilizado o extrator motorizado na coleta de amostras de lenho de árvores vivas, independente da densidade ou dureza e com danos mecânicos no tronco significamente reduzidos. O extrator é composto por um mandril, acoplando na sua extremidade uma sonda metálica com estrias em espiral de 15 x 1,5 cm (comprimento x diâmetro). Com a rotação do motor, a sonda é introduzida no tronco da árvore (altura do DAP), extraindo uma amostra cilíndrica de $10 \times 1,2 \mathrm{~cm}$ (comprimento $\mathrm{X}$ diâmetro), próxima da região de transição do cerne/alburno (Figura 1). O extrator metálico é retirado do tronco, com a amostra de lenho permanecendo presa à árvore, sendo cortada com uma pequena lâmina. 


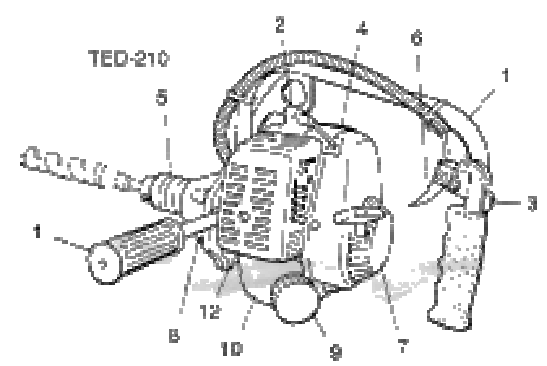

(b)

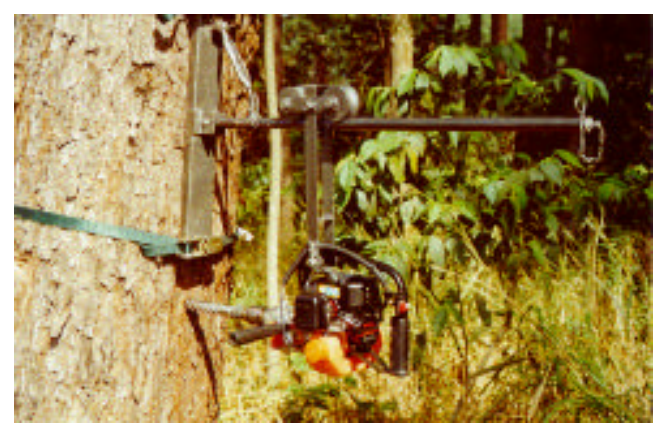

(d)

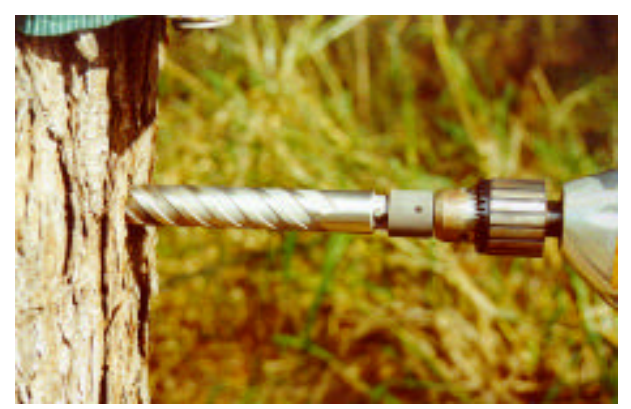

(a)

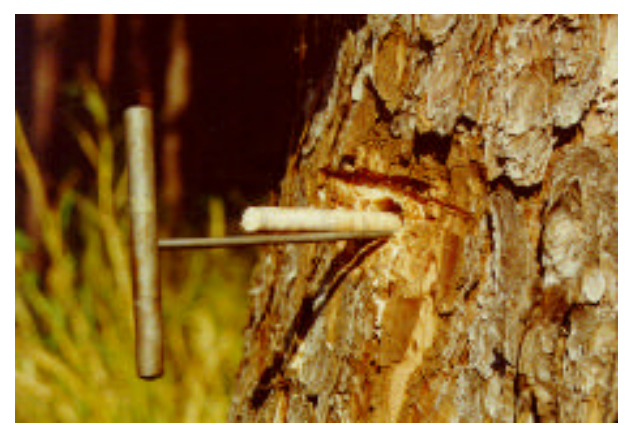

(c)

Figura 1 - Partes do extrator de amostras de madeira: (a) componentes do extrator, cabo suporte (1), ampa de plugue (2), chave de ignição (3), silenciador (4), mandril (5), gatilho acelerador (6), "starter" de recuo (7), caixa do motor (8), tampa do tanque de combustível (9), tanque de combustível (10), janelas para liberação de ar (12); (b) detalhe da sonda metálica perfurando o tronco da árvore; (c) aspecto geral mostrando o extrator acoplado no tronco da árvore; (d) detalhe da amostra de madeira sendo retirada do tronco

De cada espécie foram retiradas amostras de três espécime. O orifício deixado foi preenchido por um pedaço de madeira com a mesma espessura e comprimento do pedaço retirado, tratado com preservante CCB (Borato de Cobre Cromatado), que é um produto que confere resistência à madeira dificultando o acesso de microorganismos e insetos xilófagos, que podem danificar a estrutura da árvore. A extremidade do orifício foi então vedada com massa de vidraceiro. 
As amostras de lenho foram acondicionadas em tubos de plástico para a sua maior proteção (Shimoya \& Ramalho, 1969) e analisadas no Laboratório de Anéis de Crescimento e Anatomia de Madeira do Departamento de Ciências Florestais da ESALQ/USP.

\subsection{Análise do material botânico e amostras de madeira}

\subsubsection{Material botânico}

Foram examinadas as folhas, flores, frutos e sementes, quando presentes, para a identificação botânica do material ao nível de gênero e espécie através de chaves taxonômicas e por comparação com exsicatas do Herbário do Departamento de Produção Vegetal da Escola Superior de Agricultura "Luiz de Queiroz"/USP.

\subsubsection{Amostras de madeira}

- Análise macroscópica

Para a análise macroscópica do lenho foi utilizada uma lupa conta-fios de $10 \times$ de aumento, examinando-se os 3 planos de estudo orientados pelos elementos anatômicos e preparados com navalha no micrótomo de deslize.

$\mathrm{Na}$ análise macroscópica do lenho foram adotadas as Normas de Procedimentos em Estudos de Anatomia de Madeira do IBAMA (Coradin \& Muniz, 1992) de acordo com a norma COPANT e IAWA Committee (1989), observando-se os caracteres gerais da madeira (cor, brilho, odor, resistência ao corte manual no plano transversal, grã, textura e presença de camadas de crescimento) e as características anatômicas (parênquima: visibilidade e disposição; raios: visibilidade, tamanho e quantidade, estratificação e espelhado; poros: visibilidade, tamanho, quantidade, porosidade, agrupamento, arranjo e obstrução). A estratificação dos raios foi observada no plano longitudinal 
tangencial, o espelhado no radial e as demais estruturas anatômicas no transversal.

-Fotomacrografias

A superfície do corpo-de-prova recebeu um polimento pela abrasão em pedra de granulação fina, umedecida em água, utilizada para a afiação manual de navalhas.

O corpo-de-prova foi examinado em um estereomicroscópio ligado a um computador (com programa para captura de imagens) e obtidas as fotomacrografias.

- Análise microscópica

Preparo dos cortes histológicos e montagem de lâminas histológicas: o corpode-prova foi colocado em um béquer de $250 \mathrm{ml}$, com água destilada e glicerina (5:1), para sua hidratação por 24 horas, em repouso. Em seguida, foi colocado para fervura por 48 horas a $100{ }^{\circ} \mathrm{C}$, para o amolecimento do lenho e, deste modo, propiciar a obtenção dos cortes. Os corpos-de-prova foram imersos em álcool etílico $50^{\circ} \mathrm{GL}$ e glicerina (1:1) e desbastadas suas arestas nas dimensões de aproximadamente $1 \mathrm{~cm}^{3}$ caracterizando as superfícies transversal, longitudinal tangencial e radial. O corpo-de-prova foi fixado em micrótomo de deslize (marca Leica, modelo SM 2000 R) com o parênquima radial perpendicular (corte transversal e longitudinal tangencial) e paralelo ao operador (corte longitudinal radial). Com uma navalha tipo C (15 - $20 \mu \mathrm{m}$ de espessura) foram seccionados os cortes histológicos e removidos da navalha com um pincel chato de pelos macios, à frio, umedecendo o corpo-de-prova com uma solução alcoólica $20 \%$. Os cortes foram transferidos para uma lâmina de vidro sempre umedecidos com a solução alcoólica $20 \%$ para ficarem distendidos e divididos em 2 grupos, sendo (i) com sua coloração natural para observação do conteúdo orgânico e (ii) corados a fim de contrastar as estruturas celulares. Os cortes histológicos corados foram inicialmente clarificados com gotas aquecidas de 
hipoclorito de sódio (50\%) para extrair substâncias orgânicas (graxas, ceras e resinas) e obter melhor coloração, em função da afinidade que cada estrutura celular tem pelo corante. Os cortes histológicos foram lavados pelo gotejamento de água corrente, desidratados em uma série etílica (20, 40, 60, 80 e 100\%), e corados com safranina (solução alcoólica 50\%). Os cortes naturais não foram clarificados, passando diretamente da série alcoólica para a desidratação. Os cortes corados e naturais passaram pela solução álcool/acetato de butila (1:1), acetato de butila puro e montados em bálsamo do Canadá, entre lâmina e lamínula de vidro.

Dissociação dos elementos celulares do lenho: de cada corpo-de-prova foram retiradas fatias finas e colocadas em um frasco de vidro tampado, adicionandose a solução macerante (ácido acético e água oxigenada 100\%, 1:1) e colocados em estufa (48 horas) a $60^{\circ} \mathrm{C}$. Obtida a sua dissociação, os elementos celulares foram lavados em água corrente, corados com safranina alcoólica (50\%) e gotejadas 2 gotas de formol e montadas lâminas com glicerina (Franklin, 1937).

Medição dos elementos celulares do lenho: para cada espécime foram montadas 10 lâminas e medidas 5 fibras, totalizando 50 medições para cada espécime e característica. $\mathrm{O}$ diâmetro total, a espessura do lume e a espessura da parede das fibras foram medidos em microscópio de luz (objetiva 40x) com tambor micrométrico. O comprimento das fibras foi medido em microscópio de projeção em mesa e em sala escura (objetiva de 10x).

Para o comprimento dos elementos de vaso foram montadas 10 lâminas/espécime e medidos 3 elementos/lâmina com 30 medições/espécime, em microscópio de projeção (objetiva de 16x). Essas lâminas foram, também, utilizadas para a observação dos apêndices dos vasos em microscópio de projeção (objetiva de 16x). 
A altura dos raios (30 medições), o diâmetro dos vasos (25 medições) e o diâmetro das pontoações intervasculares (10 medições) foram medidos nas lâminas histológicas pelo programa analySIS, de imagens capturadas pela câmera digital colorida Samsung SSC-131 de um microscópio de luz marca Leica, do Agrupamento de Preservação de Madeiras da Divisão de Produtos Florestais do IPT. Os resultados das medições foram convertidos em $\mu \mathrm{m}$ e feita a sua média aritmética.

Análise microscópica do lenho

$\mathrm{Na}$ análise anatômica microscópica do lenho foram adotadas as Normas de Procedimentos em Estudos em Anatomia de Madeira do IBAMA (Coradin \& Muniz, 1992), de acordo com a COPANT e IAWA Committee (1989). As características anatômicas observadas foi: vasos (porosidade, arranjo, agrupamento, forma da secção, placas de perfuração, tilos, depósitos em vasos, pontoações intervasculares e pontoações radiovasculares); parênquima axial (disposição); e raios (largura em número de células e composição celular). As placas de perfuração, pontoações intervasculares e largura dos raios (número de células) foram observadas no plano longitudinal tangencial; as pontoações radiovasculares e a composição celular dos raios no radial e as demais características no transversal.

- Fotomicrografias

As fotomicrografias dos cortes histológicos das lâminas permanentes foram obtidas em microscópio de luz ligado a um computador (com programa para captura de imagens). 


\section{RESULTADOS}

\subsection{Descrição anatômica macro e microscópica da madeira das espécies}

selecionadas

Os resultados da descrição anatômica da madeira das diferentes espécies florestais selecionadas no presente trabalho são apresentados a seguir. As características gerais da madeira e a descrição da sua estrutura macro e microscópica são fundamentais não somente para a identificação das espécies mas, também, para a preconização dos principais usos e aplicações da madeira. 
ARARIBÁ - Centrolobium sp. FIGURA n $n^{\circ} 1$

Características gerais

Madeira com cerne e alburno distintos pela cor, sendo o alburno amarelo e o cerne amarelo-vivo ao castanho avermelhado, com veios enegrecidos. Brilho moderado, odor agradável, moderadamente dura ao corte manual no plano transversal, grã direita, textura média e camadas de crescimento distintas.

Descrição macroscópica

Parênquima axial visível somente sob lente de 10x, com disposição paratraqueal, aliforme de extensão losangular. Raios visíveis somente sob lente de 10x, médios, numerosos, estratificados. Poros visíveis a olho nu, pequenos, pouco numerosos, com porosidade difusa, solitários, vazios e alguns obstruídos por resina avermelhada. No plano longitudinal tangencial os raios são visíveis somente sob lente de 10x, baixos, estratificados com estratificação regular e linhas vasculares retilíneas. No plano longitudinal radial o espelhado dos raios é pouco contrastado. Camadas de crescimento distintas individualizadas por zonas fibrosas tangenciais mais escuras.

Descrição microscópica

Vasos com porosidade difusa, arranjo tangencial, solitários na maioria e raros múltiplos, forma da secção ovalada a circular, placas de perfuração simples, diâmetro tangencial de $94,2 \mu \mathrm{m}$, elementos de vaso com 0,26 $\mathrm{mm}$ de comprimento, sem apêndices, tilos não abundantes, depósitos em vasos pouco abundantes de cor marrom, pontoações intervasculares alternas, arredondadas e guarnecidas, com diâmetro tangencial de 8,2 $\mu \mathrm{m}$, e pontoações radiovasculares semelhantes æ̀̀ intervasculares. Parênquima axial aliforme de extensão losangular de aletas curtas, ou quase vasicêntrico. Fibras com 1,2 mm de comprimento e paredes delgadas a espessas. Raios unisseriados na maioria, com raros bisseriados, com $0,167 \mathrm{~mm}$ de altura, homocelulares com todas as células quadradas e eretas, estratificados. Cristais presentes em células do parênquima axial. Camadas de crescimento distintas individualizadas pela variação do lume das fibras 
CANXIM - Pachystroma ilicifolium

FIGURA $n^{\circ} 2$

Características gerais

Madeira com cerne e alburno indistintos pela cor, com coloração branco-palha amarelada. Brilho moderado, odor imperceptível, dura ao corte manual no plano transversal, grã direita, textura fina e camadas de crescimento distintas.

Descrição macroscópica

Parênquima axial visível somente sob lente de 10x, em linhas ou faixas estreitas ligando os poros. Raios visíveis somente sob lente de 10x, finos e numerosos. Poros visíveis somente sob lente de 10x, pequenos, numerosos, com porosidade difusa, múltiplos na maioria, em cadeias e vazios. No plano longitudinal tangencial os raios são visíveis somente sob lente de 10x, baixos, e linhas vasculares retilíneas. No plano longitudinal radial o espelhado dos raios é pouco contrastado. Camadas de crescimento demarcadas por zonas fibrosas tangenciais mais escuras, e pelo parênquima terminal.

Descrição microscópica

Vasos com porosidade difusa, arranjo diagonal e/ou radial, solitários e múltiplos em cadeias radiais, forma da secção arredondada, placas de perfuração simples, diâmetro tangencial de $71,4 \mu \mathrm{m}$, elementos de vaso com $0,55 \mathrm{~mm}$ de comprimento, com presença de 1,2 ou ausência de apêndices, tilos não abundantes, depósitos nos vasos pouco abundantes de cor marrom, pontoações intervasculares opostas, arredondadas, com diâmetro tangencial de 10,2 $\mu \mathrm{m}$, e pontoações radiovasculares semelhantes ì intervasculares. Parênquima axial em linhas finas ligando os poros. Fibras com 1,23 mm de comprimento e paredes muito espessas. Raios unisseriados, com 0,287 $\mathrm{mm}$ de altura, heterocelulares com células procumbentes e 2 a 3 fileiras marginais de células quadradas e eretas, não estratificados. Cristais presentes em células de parênquima axial. $\underline{\text { Camadas }}$ de crescimento individualizadas pela variação do lume das fibras. 
JEQUITIBÁ-BRANCO - Cariniana estrellensis

FIGURA $n^{\circ} 3$

Descrição dos caracteres gerais

Madeira com cerne e alburno indistintos pela cor, com coloração brancoencardido ou levemente rosado. Brilho moderado, odor imperceptível, moderadamente dura ao corte manual no plano transversal, grã direita, textura média e camadas de crescimento pouco distintas.

Descrição macroscópica

Parênquima axial visível a olho nu, em linhas finas, ordenadas e aproximadas, formando um reticulado com os raios. Raios visíveis a olho nu, médios e poucos. Poros visíveis a olho nu, pequenos a médios, poucos com porosidade difusa, solitários e múltiplos, vazios. No plano longitudinal tangencial os raios são visíveis somente sob lente de 10x, baixos, e linhas vasculares retilíneas. No plano longitudinal radial o espelhado dos raios é pouco contrastado. Camadas de crescimento distintas individualizadas por zonas fibrosas tangenciais mais escuras.

Descrição microscópica

Vasos com porosidade difusa, arranjo tangencial, solitários e múltiplos em cadeias radiais, forma da secção arredondada, placas de perfuração simples, com diâmetro tangencial de 125,5 $\mu \mathrm{m}$, elementos vasculares com 0,4 mm de comprimento, com presença de 1,2 ou ausência de apêndices, tilos não abundantes, pontoações intervasculares alternas, arredondadas, com diâmetro tangencial de 10,0 $\mu \mathrm{m}$, e pontoações radiovasculares semelhantes às intervasculares. Parênquima axial em linhas finas, formando um reticulado com os raios. Fibras com 1,53 mm de comprimento e paredes muito espessas. $\underline{\text { Raios }}$ trisseriados e alguns unisseriados, com 0,334 mm de altura, homocelulares com todas as células procumbentes. Cristais presentes em células de parênquima axial. Sílica presente em células de parênquima axial e radial. $\underline{\text { Camadas de }}$ crescimento individualizadas pela variação do lume das fibras. 
JEQUITIBÁ-ROSA - Cariniana legalis $\quad$ FIGURA no 4

Descrição dos caracteres gerais

Madeira com cerne e alburno indistintos pela cor, com coloração bege-rosadoescuro. Brilho moderado, odor imperceptível, moderadamente dura ao corte manual no plano transversal, grã direita, textura média e camadas de crescimento distintas.

Descrição macroscópica

Parênquima axial visível a olho nu, em linhas finas, ordenadas e aproximadas, formando com os raios um reticulado. Raios visíveis a olho nu, médios e poucos. Poros visíveis a olho nu, pequenos a médios, pouco numerosos, com porosidade difusa, solitários e múltiplos, com conteúdo brilhante de tilas. No plano longitudinal angencial os raios são visíveis somente sob lente de 10x, baixos, e linhas vasculares retilíneas. No plano longitudinal radial o espelhado dos raios é pouco contrastado. Camadas de crescimento distintas, individualizadas por zonas fibrosas tangenciais mais escuras.

Descrição microscópica

Vasos com porosidade difusa, arranjo tangencial, solitários e múltiplos, forma da secção arredondada, placas de perfuração simples, com diâmetro tangencial de $108,1 \mu \mathrm{m}$, elementos vasculares com 0,5 mm de comprimento, com ausência de apêndices, tilos abundantes, pontoações intervasculares alternas, arredondadas, com diâmetro tangencial de 9,6 $\mu \mathrm{m}$ e pontoações radiovasculares semelhantes às intervasculares. Parênquima axial em linhas finas e aproximadas, formando um reticulado com os raios. Fibras com 1,4 mm de comprimento e paredes delgadas a espessas. Raios uni e bisseriados, com $0,509 \mathrm{~mm}$ de altura, homocelulares com todas as células procumbentes. $\underline{\text { Cristais }}$ presentes em células de parênquima axial. Sílica em pouca quantidade em células de parênquima radial. Camadas de crescimento individualizadas por zonas fibrosas tangenciais mais escuras. 
FRUTA-DE-POMBA - Erytrhoxylum sp. $\quad$ FIGURA n $n^{\circ}$

Descrição dos caracteres gerais

Madeira com cerne e alburno indistintos pela cor, com coloração bege-rosada. Brilho moderado, odor imperceptível, moderadamente dura ao corte manual no plano transversal, grã direita, textura média e camadas de crescimento distintas. Descrição macroscópica

Parênquima axial visível somente sob lente de 10x, paratraqueal vasicêntrico. Raios visíveis somente sob lente de 10x, finos e numerosos. Poros de dois tamanhos, sendo os maiores visíveis a olho nu e os menores somente sob lente de 10x, médios e pequenos, porosidade em anéis porosos, solitários na maioria, vazios. No plano longitudinal tangencial os raios são visíveis somente sob lente de 10x, baixos, e linhas vasculares retilíneas. No plano longitudinal radial o espelhado dos raios é contrastado. Camadas de crescimento distintas, individualizadas por distribuição dos poros em anéis porosos.

Descrição microscópica

Vasos com porosidade em anéis porosos, arranjo tangencial, solitários e múltiplos, predominando os solitários, forma da secção arredondada, placas de perfuração simples, com diâmetro tangencial de $148,4 \mu \mathrm{m}$, elementos vasculares com 0,35 mm de comprimento, com 2 ou ausência de apêndices, tilos não abundantes, pontoações intervasculares alternas arredondadas, com diâmetro tangencial de 6,9 $\mu \mathrm{m}$, pontoações radiovasculares semelhantes æ̀s intervasculares. Parênquima axial paratraqueal vasicêntrico escasso. Fibras com $1,06 \mathrm{~mm}$ de comprimento e paredes delgadas a espessas. Raios trisseriados, com $0,353 \mathrm{~mm}$ de altura, heterocelulares com células procumbentes e 1 fileira marginal de células quadradas e eretas. Camadas de crescimento individualizadas também pela variação do lume das fibras. 
IMBUIA - Ocotea porosa $\quad$ FIGURA n ${ }^{\circ} 6$

Descrição dos caracteres gerais

Madeira com cerne e alburno indistintos pela cor, coloração pardo-claroamarelado ao pardo-acastanhado. Brilho acentuado, odor perceptível agradável, moderadamente dura ao corte manual no plano transversal, grã direita, textura média e camadas de crescimento distintas.

Descrição macroscópica

Parênquima axial visível somente sob lente de 10x, paratraqueal vasicêntrico. Raios visíveis somente sob lente de 10x, médios e poucos. Poros visíveis somente sob lente de 10x, pequenos, poucos, com porosidade difusa, solitários e múltiplos contendo tilos no seu interior. No plano longitudinal tangencial os raios são visíveis somente sob lente de 10x, baixos, e linhas vasculares retilíneas. No plano longitudinal radial o espelhado dos raios é contrastado. Camadas de crescimento individualizadas por zonas fibrosas tangenciais mais escuras.

Descrição microscópica

Vasos com porosidade difusa, arranjo tangencial, solitários e múltiplos, forma da secção arredondada, placas de perfuração simples, diâmetro tangencial de 94,8 $\mu \mathrm{m}$, elementos vasculares com $0,5 \mathrm{~mm}$ de comprimento, com 1, 2 ou ausência de apêndices, tilos não abundantes, depósitos nos vasos pouco abundantes de cor marrom claro, pontoações intervasculares alternas, arredondadas, com diâmetro tangencial de $11,0 \mu \mathrm{m}$, pontoações radiovasculares semelhantes às intervasculares. Fibras septadas, com $1 \mathrm{~mm}$ de comprimento e paredes delgadas a espessas. Parênquima axial paratraqueal vasicêntrico e algumas células difusas. Raios bisseriados na maioria e alguns trisseriados, altura de $0,264 \mathrm{~mm}$, heterocelulares com células procumbentes e 1 fileira marginal de células quadradas e eretas. Camadas de crescimento distintas, individualizadas pelo achatamento do lume das fibras. 
CANAFÍSTULA - Cassia ferruginea

FIGURA $n^{\circ} 7$

Descrição dos caracteres gerais

Madeira com cerne e alburno indistintos pela cor, com coloração bege-castanhoavermelhado, sem brilho, odor imperceptível, moderadamente dura ao corte manual no plano transversal, grã direita, textura média e camadas de crescimento distintas.

Descrição macroscópica

Parênquima axial visível a olho nu, paratraqueal aliforme losangular com expansões curtas e marginal em linhas finas. Raios visíveis somente sob lente de 10x, finos e poucos. Poros visíveis a olho nu, médios, poucos, solitários na maioria, com porosidade difusa e vazios. No plano longitudinal tangencial os raios são visíveis somente sob lente de 10x, baixos, e linhas vasculares retilíneas. No plano longitudinal radial o espelhado dos raios é pouco contrastado. Camadas de crescimento distintas individualizadas por zonas fibrosas tangenciais mais escuras e pelo parênquima marginal.

Descrição microscópica

Vasos com porosidade difusa, arranjo tangencial, solitários na maioria e alguns múltiplos de 2 a 3, forma da secção arredondada, placas de perfuração simples, com diâmetro tangencial de 131,3 $\mu \mathrm{m}$, elementos vasculares com 0,25 mm de comprimento, com 1 ou ausência de apêndices, tilos abundantes, depósitos nos vasos abundantes de cor marrom, pontoações intervasculares alternas, arredondadas, com 6,1 $\mu \mathrm{m}$ de diâmetro tangencial, pontoações radiovasculares semelhantes æ̀ intervasculares. Parênquima axial paratraqueal aliforme losangular e linhas de parênquima marginal. Fibras septadas com $1 \mathrm{~mm}$ de comprimento e paredes delgadas a espessas. Raios uni e bisseriados, com altura de $0,183 \mathrm{~mm}$, homocelulares com todas as células procumbentes. Camadas de crescimento também individualizadas pelo achatamento do lume das fibras. 
PAU-PEREIRA- Platycyamus regnelli

FIGURA $n^{\circ} 8$

Descrição dos caracteres gerais

Madeira com cerne e alburno indistintos pela cor, sendo o alburno amarelado e o cerne castanho-avermelhado, sem brilho, odor imperceptível, dura ao corte manual no plano transversal, grã direita, textura média e camadas de crescimento distintas.

Descrição macroscópica

Parênquima axial visível a olho nu, paratraqueal aliforme de extensão losangular confluente e em finas linhas marginais. Raios visíveis a olho nu, médios e poucos. Poros visíveis a olho nu, médios, poucos, com porosidade difusa, solitários e múltiplos, sendo alguns obstruídos por tilos. No plano longitudinal tangencial os raios são visíveis somente sob le nte de 10x, baixos, estratificados e linhas vasculares retilíneas. No plano longitudinal radial o espelhado dos raios é pouco contrastado. Camadas de crescimento distintas individualizadas por linhas de parênquima marginal.

Descrição microscópica

Vasos com porosidade difusa, arranjo tangencial, solitários e alguns múltiplos de 2 a 4, forma da secção ovalada, placas de perfuração simples, com diâmetro tangencial de 142,2 $\mu \mathrm{m}$, elementos vasculares com 0,4 mm de comprimento, com ausência de apêndices, tilos não abundantes, depósitos nos vasos pouco abundantes de cor amarelada, pontoações intervasculares alternas, arredondadas, guarnecidas, com diâmetro tangencial de $13,0 \mu \mathrm{m}$, pontoações radiovasculares semelhantes æ̀̀ intervasculares. Parênquima axial aliforme confluente, formando faixas irregulares e em linhas marginais. Fibras com 0,4 $\mathrm{mm}$ de comprimento e paredes muito espessas. Raios multisseriados na maioria e alguns unisseriados, com altura de 0,399 mm, heterocelulares com células procumbentes e 1 fileira marginal de células quadradas e eretas, com

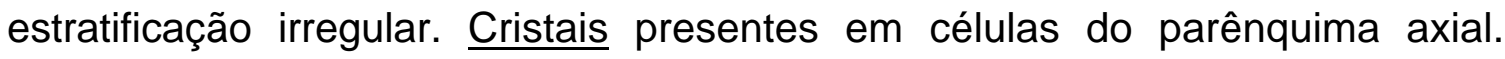
Camadas de crescimento distintas individualizadas por linhas de parênquima marginal. 


\section{PEROBA-ROSA - Aspidosperma polyneuron FIGURA n 9}

\section{Descrição dos caracteres gerais}

Madeira com cerne e alburno distintos pela cor, sendo o cerne rosado e o alburno amarelado, sem brilho, odor imperceptível, moderadamente dura ao corte manual no plano transversal, grã direita, textura fina e camadas de crescimento distintas.

\section{Descrição macroscópica}

Parênquima axial invisível mesmo sob lente de 10x. Raios visíveis somente sob lente de 10x, finos e numerosos. Poros visíveis somente sob lente de 10x, pequenos, muito numerosos, porosidade difusa, solitários, vazios. No plano longitudinal tangencial os raios são visíveis somente sob lente de 10x, baixos, e linhas vasculares retilíneas. No plano longitudinal radial o espelhado dos raios é contrastado. Camadas de crescimento distintas individualizadas por zonas fibrosas tangenciais mais escuras.

Descrição microscópica

Vasos com porosidade difusa, arranjo tangencial, solitários na maioria e alguns geminados, forma da secção arredondada, placas de perfuração simples, diâmetro tangencial de 52,9 $\mu \mathrm{m}$, elementos vasculares com $0,5 \mathrm{~mm}$ de comprimento, com 1, 2 ou ausência de apêndices, tilos não abundantes, pontoações intervasculares alternas, arredondadas, com diâmetro tangencial de 7,3 $\mu \mathrm{m}$, e pontoações radiovasculares semelhantes às intervasculares. Parênquima axial apotraqueal, difuso com células esparsas entre as fibras. Fibras com $2 \mathrm{~mm}$ de comprimento e paredes muito espessas. Raios bi e trisseriados, predominando os bisseriados, com altura de $0,343 \mathrm{~mm}$, homocelulares com todas as células procumbentes. Cristais presentes em células do parênquima axial. Camadas de crescimento individualizadas pela variação do lume das fibras. 
GUARANTÃ - Esenbeckia leiocarpa FIGURA no 10

Descrição dos caracteres gerais

Madeira com cerne e alburno pouco distintos pela cor, sendo o cerne amarelodourado e o alburno com a mesma tonalidade, um pouco mais claro, com brilho moderado, odor imperceptível, dura ao corte manual no plano transversal, grã direita, textura fina e camadas de crescimento distintas.

Descrição macroscópica

Parênquima axial visível somente sob lente de 10x, em finas linhas marginais. Raios visíveis somente sob lente de 10x, finos e numerosos. Poros visíveis somente sob lente de 10x, pequenos, muito numerosos e múltiplos em cadeias radiais. No plano longitudinal tangencial os raios são visíveis somente sob lente de 10x, baixos, estratificados e linhas vasculares retilíneas. No plano longitudinal radial o espelhado dos raios é contrastado. Camadas de crescimento demarcadas pelas linhas do parênquima marginal.

Descrição microscópica

Vasos com porosidade difusa, arranjo tangencial, agrupados em cadeias radiais de 2 a 4 e alguns solitários, forma da secção arredondada, placas de perfuração simples, com diâmetro tangencial de 68,1 $\mu \mathrm{m}$, elementos vasculares com 0,3 mm de comprimento, com 1 ou ausência de apêndices, tilos não abundantes, pontoações intervasculares alternas, arredondadas, com diâmetro tangencial de 4,8 $\mu \mathrm{m}, \mathrm{e}$ pontoações radiovasculares semelhantes æ̀ intervasculares. Parênquima axial paratraqueal escasso e em linhas marginais. Fibras com 1,2 $\mathrm{mm}$ de comprimento e paredes muito espessas. Raios uni, bi, tri e multisseriados, com altura de 0,306 mm, heterocelulares com células procumbentes e 1 a 3 fileiras marginais de células quadradas e eretas, estratificados. Cristais presentes em células do parênquima axial e do parênquima radial. Camadas de crescimento individualizadas também pelo aumento do lume das fibras. 
CUMARU - Dipteryx sp. FIGURA n $n^{\circ} 11$

Descrição dos caracteres gerais

Madeira com cerne e alburno distintos pela cor, sendo o cerne castanho e o alburno amarelado, com brilho moderado, odor imperceptível, moderadamente dura ao corte manual no plano transversal, grã inclinada, textura média e camadas de crescimento pouco distintas.

Descrição macroscópica

Parênquima axial visível somente sob lente de 10x, paratraqueal aliforme de expansão losangular, formando pequenas confluências. Raios visíveis somente sob lente de 10x, médios e poucos. Poros visíveis a olho nu, médios, poucos, com porosidade difusa, solitários na maioria. No plano longitudinal tangencial os raios são visíveis somente sob lente de 10x, baixos, estratificados e linhas vasculares retilíneas. No plano longitudinal radial o espelhado dos raios é pouco contrastado. Camadas de crescimento distintas individualizadas por zonas fibrosas tangenciais mais escuras.

Descrição microscópica

Vasos com porosidade difusa, arranjo tangencial, solitários na maioria, alguns geminados e raros múltiplos de 3 a 6 , forma da secção arredondada, placas de perfuração simples, com diâmetro tangencial de 96,6 $\mu \mathrm{m}$, elementos vasculares com $0,3 \mathrm{~mm}$ de comprimento, com ausência de apêndices, tilos não abundantes, pontoações intervasculares alternas, ovaladas e guarnecidas, com diâmetro tangencial de 10,2 $\mu \mathrm{m}$, pontoações radiovasculares semelhantes æ̀s intervasculares. Parênquima axial aliforme losangular, formando pequenas confluências. Fibras com $1 \mathrm{~mm}$ de comprimento e paredes muito espessas. Raios unisseriados na maioria e alguns bisseriados, com altura de 0,196 mm, homocelulares com todas as células procumbentes, estratificados. Cristais presentes em células do parênquima axial. Camadas de crescimento individualizadas pela variação do lume das fibras. 


\section{ANGICO-PRETO - Piptadenia macrocarpa FIGURA $n^{\circ} 12$}

Descrição dos caracteres gerais

Madeira com cerne e alburno distintos pela cor, sendo o cerne castanhoavermelhado-escuro, com veios enegrecidos e o alburno bege-amarelado, sem brilho, odor imperceptível, moderadamente dura ao corte manual no plano transversal, grã ondulada, textura média e camadas de crescimento pouco distintas.

Descrição macroscópica

Parênquima axial visível somente sob lente de 10x, paratraqueal vasicêntrico escasso e em finas linhas marginais. Raios visíveis somente sob lente de 10x, finos, poucos. Poros visíveis somente sob lente de 10x, pequenos, numerosos, porosidade difusa, solitários e múltiplos. No plano longitudinal tangencial os raios são visíveis somente sob lente de 10x, baixos, e linhas vasculares irregulares. No plano longitudinal radial o espelhado dos raios é pouco

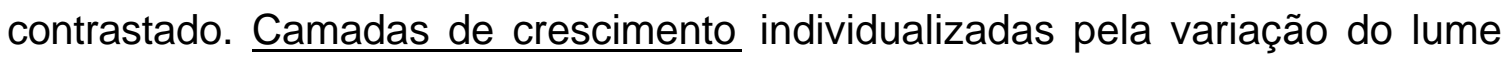
das fibras.

Descrição microscópica

Vasos com porosidade difusa, arranjo tangencial, solitários e múltiplos, forma da secção arredondada, placa de perfuração simples, com diâmetro tangencial de $157,0 \mu \mathrm{m}$, elementos vasculares com $0,25 \mu \mathrm{mm}$ de comprimento, com 1 ou ausência de apêndices, tilos não abundantes, depósitos nos vasos marrom claro, não abundantes, pontoações intervasculares alternas, arredondadas, com diâmetro tangencial de 8,5 $\mu \mathrm{m}$, pontoações radiovasculares semelhantes æ̀े intervasculares. Parênquima axial paratraqueal vasicêntrico, também aliforme com pequenas confluências e em linhas marginais. Fibras com $1 \mathrm{~mm}$ de comprimento e paredes muito espessas. Raios tri e multisseriados, com 0,274 $\mathrm{mm}$ de altura, homocelulares com todas as células procumbentes. Cristais presentes em células do parênquima axial. Camadas de crescimento individualizadas pelo achatamento do lume das fibras. 
PAU-FERRO - Caesalpinia ferrea

FIGURA $n^{\circ} 13$

Descrição dos caracteres gerais

Madeira com cerne e alburno distintos pela cor, sendo o cerne castanho-escuro a enegrecido e o alburno bege-amarelado, brilho moderado, odor imperceptível, dura ao corte manual no plano transversal, grã inclinada, textura fina e camadas de crescimento pouco distintas.

Descrição macroscópica

Parênquima axial visível somente sob lente de 10x, paratraqueal aliforme linear, confluente, formando faixas longas estreitas e irregulares e também confluente em trechos curtos. Raios visíveis somente sob lente de 10x, finos e poucos. Poros visíveis somente sob lente de 10x, pequenos, pouco numerosos, porosidade difusa, solitários e múltiplos. No plano longitudinal tangencial os raios são visíveis somente sob lente de 10x, baixos, estratificados, e linhas vasculares irregulares. No plano longitudinal radial o espelhado dos raios é contrastado. Camadas de crescimento distintas individualizadas eventualmente por linhas finas de parênquima confluente e zonas fibrosas tangenciais mais escuras.

Descrição microscópica

Vasos com porosidade difusa, arranjo tangencial, solitários na maioria, forma da secção arredondada, placas de perfuração simples, diâmetro tangencial de 92,6 $\mu \mathrm{m}$, elementos vasculares com $0,3 \mathrm{~mm}$ de comprimento, com ausência de apêndices, tilos abundantes, depósitos nos vasos abundantes com cor marrom escura, pontoações intervasculares alternas arredondadas, com diâmetro tangencial de 8,3 $\mu \mathrm{m}$, pontoações radiovasculares semelhantes æ̀s intravasculares. Parênquima axial aliforme losangular confluente formando faixas e em linhas de parênquima marginal. Fibras com 1,1 mm de comprimento e paredes muito espessas. Raios bi e trisseriados, com altura de $0,184 \mathrm{~mm}$, homocelulares com todas as células procumbentes, estratificados. Cristais em células do parênquima axial. Sílica presente no parênquima radial. $\underline{\text { Camadas de }}$ crescimento individualizadas pela variação do lume das fibras. 
GUARAIÚVA - Securinega guarayuva

FIGURA $n^{\circ} 14$

Descrição dos caracteres gerais

Madeira com cerne e alburno indistintos pela cor, com coloração bege-claroamarelado, sem brilho, odor imperceptível, macia ao corte manual no plano transversal, grã direita, textura fina e camadas de crescimento pouco distintas.

Descrição macroscópica

Parênquima axial visível somente sob lente de 10x, difuso. Raios visíveis somente sob lente de 10x, finos, muitos. Poros pouco visíveis mesmo sob lente de 10x, pequenos, muito numerosos, múltiplos em pequenas cadeias radiais. No plano longitudinal tangencial os raios são visíveis somente sob lente de 10x, baixos, e linhas vasculares retilíneas. No plano longitudinal radial o espelhado dos raios é pouco contrastado. Camadas de crescimento distintas individualizadas por zonas fibrosas tangenciais mais escuras.

Descrição microscópica

Vasos com porosidade difusa, arranjo tangencial, múltiplos em pequenas cadeias radiais, forma da secção arredondada, placas de perfuração simples, diâmetro tangencial de $41,6 \mu \mathrm{m}$, elementos vasculares com comprimento de 0,7 $\mathrm{mm}$, com 1, 2 ou ausência de apêndices, tilos abundantes, depósitos nos vasos não abundantes de cor amarelo claro, pontoações intervasculares alternas, arredondadas, com diâmetro tangencial de 3,7 $\mu \mathrm{m}$, pontoações radiovasculares semelhantes às intervasculares. Parênquima axial difuso. Fibras com 2,1 mm de comprimento e paredes muito espessas. Raios uni e bisseriados, com altura de $0,478 \mathrm{~mm}$, heterocelulares com células procumbentes e 2 fileiras marginais de células quadradas e eretas. Sílica em abundância em células do parênquima radial. Camadas de crescimento individualizadas pela variação do lume das fibras. 
JACARANDÁ-PAULISTA - Machaerium villosum

FIGURA $n^{\circ} 15$

Descrição dos caracteres gerais

Madeira com cerne e alburno distintos pela cor, sendo o cerne pardoacastanhado e alburno bege-amarelado, sem brilho, odor imperceptível, dura ao corte manual no plano transversal, grã ondulada, textura média e camadas de crescimento pouco distintas.

Descrição macroscópica

Parênquima axial visível a olho nu, paratraqueal aliforme losangular e alguns formando linhas aproximadas. Raios visíveis somente sob lente de 10x, médios, poucos. Poros visíveis a olho nu, médios, pouco numerosos, com porosidade difusa, solitários na maioria. No plano longitudinal tangencial os raios são visíveis somente sob lente de 10x, baixos, estratificados e Inhas vasculares irregulares. No plano longitudinal radial o espelhado dos raios é pouco contrastado. Camadas de crescimento distintas individualizadas por zonas fibrosas tangenciais mais escuras.

Descrição microscópica

Vasos com porosidade difusa, arranjo tangencial, solitários na maioria, forma da secção arredondada, placas de perfuração simples, com diâmetro tangencial de $88,4 \mu \mathrm{m}$, elementos vasculares com $0,25 \mathrm{~mm}$ de comprimento, ausência de apêndices, tilos não abundantes, depósitos nos vasos abundantes de cor marrom, pontoações intervasculares alternas, arredondadas e guarnecidas, com diâmetro tangencial de 7,6 $\mu \mathrm{m}$, pontoações radiovasculares semelhantes æ̀s intervasculares, mas não guarnecidas. Parênquima axial aliforme, e aliforme confluente em trechos curtos e em trechos longos formando faixas. Fibras com $0,85 \mathrm{~mm}$ de comprimento e paredes delgadas a espessas. Raios uni, bi e trisseriados, com altura de $0,180 \mathrm{~mm}$, heterocelulares com células procumbentes e 1 fileira marginal de células quadradas e eretas, estratificados. Cristais presentes em células do parênquima axial. Camadas de crescimento individualizadas pela variação do lume das fibras. 
PAU-JACARÉ - Piptadenia gonoacantha

FIGURA $n^{\circ} 16$

Descrição dos caracteres gerais

Madeira com cerne e alburno indistintos pela cor, cerne com coloração begeclaro, sem brilho, odor imperceptível, moderadamente dura ao corte manual no plano transversal, grã ondulada, textura média e camadas de crescimento distintas.

Descrição macroscópica

Parênquima axial visível somente sob lente de 10x, marginal em linhas finas e paratraqueal vasicêntrico escasso. Raios visíveis somente sob lente de 10x, médios, poucos. Poros, os maiores visíveis a olho nu, médios, pouco numerosos, com porosidade em anéis semi-porosos, solitários e múltiplos. No plano longitudinal tangencial os raios são visíveis somente sob lente de 10x, baixos, e linhas vasculares irregulares. No plano longitudinal radial o espelhado dos raios é pouco contrastado. Camadas de crescimento distintas individualizadas por distribuição dos poros em anéis semi-porosos e pelas linhas do parênquima marginal.

Descrição microscópica

Vasos com porosidade em anéis semi-porosos, arranjo tangencial, solitários na maioria, forma da secção arredondada, placas de perfuração simples, diâmetro tangencial de 133,3 $\mu \mathrm{m}$, elementos vasculares com 0,25 mm de comprimento, ausência de apêndices, tilos pouco abundantes, pontoações intervasculares alternas, arredondadas, com diâmetro tangencial de 7,8 $\mu \mathrm{m}$, pontoações radiovasculares semelhantes às intervasculares. Parênquima axial aliforme losangular e em alguns trechos confluente formando faixas, vasicêntrico e em linhas finas. Fibras com $0,89 \mathrm{~mm}$ de comprimento e paredes delgadas a espessas. Raios bi, tri e multisseriados, com altura de $0,227 \mathrm{~mm}$, homocelulares com todas as células procumbentes. Cristais presentes em células do parênquima axial. Camadas de crescimento também individualizadas pela variação do lume das fibras. 
GUAPURUVU - Schizolobium parahyba

FIGURA $n^{\circ} 17$

Descriçaõ dos caracteres gerais

Madeira com cerne e alburno indistintos pela cor, cerne com coloração brancopalha, sem brilho, odor imperceptível, macia ao corte manual no plano transversal, grã direita, textura média e camadas de crescimento distintas.

Descrição macroscópica

Parênquima axial visível a olho nu, marginal em linhas finas e paratraqueal vasicêntrico. Raios visíveis a olho nu, médios, poucos. Poros visíveis a olho nu, grandes, poucos, com porosidade difusa, solitários na maioria. No plano longitudinal tangencial os raios são visíveis somente sob lente de 10x, baixos, e linhas vasculares retilíneas. No plano longitudinal radial o espelhado dos raios é pouco contrastado. Camadas de crescimento distintas individualizadas por zonas fibrosas tangenciais mais escuras e pelas linhas do parênquima marginal. Descrição microscópica

Vasos com porosidade difusa, arranjo tangencial, solitários e múltiplos, forma da secção arredondada, placas de perfuração simples, com diâmetro tangencial de $224,3 \mu \mathrm{m}$, elementos vasculares com $0,28 \mathrm{~mm}$ de comprimento, com nenhum ou 1 apêndice, tilos não abundantes, pontoações intervasculares alternas, arredondadas, com diâmetro tangencial de 9,8 $\mu \mathrm{m}$, pontoações radiovasculares semelhantes æ̀ intervasculares. Parênquima axial aliforme losangular, vasicêntrico e em linhas finas. Fibras com 1,03 mm de comprimento e paredes delgadas a espessas. Raios uni e bisseriados, com altura de 0,251 mm, homocelulares com todas as células procumbentes. Camadas de crescimento também individualizadas pelo achatamento do lume das fibras. 
COPAÍBA - Copaifera langsdorfii $\quad$ FIGURA n 18

Descrição dos caracteres gerais

Madeira com cerne e alburno indistintos pela cor, cerne com coloração castanho a castanho-avermelhada, sem brilho, odor imperceptível, moderadamente dura ao corte manual no plano transversal, grã direita, textura média e camadas de crescimento distintas.

Descrição macroscópica

Parênquima axial visível a olho nu, marginal em faixas e paratraqueal visível somente sob lente de 10x, vasicêntrico e aliforme. Raios visíveis a olho nu, médios, poucos. Poros visíveis a olho nu, médios, pouco numerosos, com porosidade difusa, solitários na maioria. Presença de canais secretores axiais localizadas nas faixas marginais No plano longitudinal tangencial os raios são visíveis somente sob lente de 10x, baixos, e linhas vasculares retilíneas. No plano longitudinal radial o espelhado dos raios é pouco contrastado. $\underline{\text { Camadas }}$ de crescimento distintas individualizadas pelas faixas do parênquima marginal. Descrição microscópica

Vasos com porosidade difusa, arranjo tangencial, solitários e múltiplos, forma da secção arredondada, placas de perfuração simples, com diâmetro tangencial de $102,4 \mu \mathrm{m}$, elementos vasculares com 0,29 mm de comprimento, ausência de apêndices, tilos não abundantes, pontoações intervasculares alternas, arredondadas, com diâmetro tangencial de 9,6 $\mu \mathrm{m}$, pontoações radiovasculares semelhantes ì intervasculares. Parênquima axial vasicêntrico e aliforme e algumas faixas de parênquima marginal. Fibras com 1,16 mm de comprimento e paredes delgadas a espessas. Raios bi e trisseriados, com altura de 0,494 mm, heterocelulares com 1 a 2 fileiras marginais de células quadradas. Cristais presentes em células do parênquima axial e radial. Camadas de crescimento também individualizadas pela variação do lume das fibras. 
QUARESMEIRA - Tibouchina granulosa

FIGURA no 19

Descrição dos caracteres gerais

Madeira com cerne e alburno distintos pela cor, sendo o cerne com coloração castanho escuro e o alburno amarelo -queimado, sem brilho, odor imperceptível, moderadamente dura ao corte manual no plano transversal, grã direita, textura média e camadas de crescimento indistintas.

Descrição macroscópica

Parênquima axial visível apenas sob lente de 10x, em linhas que ligam os poros. Raios visíveis a olho nu, médios, poucos. Poros visíveis somente sob lente de 10x, pequenos, numerosos, com porosidade difusa, solitários e múltiplos, alguns obstruídos por substância amarelada. No plano longitudinal tangencial os raios são visíveis somente sob lente de 10x, baixos, e linhas vasculares retilíneas. No plano longitudinal radial o espelhado dos raios é pouco contrastado.

Descrição microscópica

Vasos com porosidade difusa, arranjo tangencial, solitários e múltiplos, forma da secção arredondada, placas de perfuração simples, diâmetro tangencial de $154,5 \mu \mathrm{m}$, elementos vasculares com comprimento de $0,35 \mathrm{~mm}$, com nenhum ou 2 apêndices, tilos pouco abundantes, pontoações intervasculares alternas, arredondadas, com diâmetro tangencial de 11,5 $\mu \mathrm{m}$, pontoações radiovasculares semelhantes ì intervasculares, mas maiores. Parênquima axial aliforme confluente. Fibras com 0,81 $\mathrm{mm}$ de comprimento e paredes delgadas a espessas. Raios multisseriados, com altura de $0,718 \mathrm{~mm}$, heterocelulares onde misturam-se células procumbentes e células quadradas. 
CAMBARÁ - Gochnatia polymorpha FIGURA n 20

Descrição dos caracteres gerais

Madeira com cerne e alburno indistintos pela cor, o cerne com coloração castanho claro, com brilho moderado, odor imperceptível, moderadamente dura ao corte manual no plano transversal, grã direita, textura média e camadas de crescimento pouco distintas.

Descrição macroscópica

Parênquima axial visível somente sob lente de 10x, em linhas marginais e vasicêntrico. Raios visíveis somente sob lente de 10x, finos, numerosos. Poros visíveis somente sob lente de 10x, pequenos, numerosos, com porosidade difusa, arranjo diagonal, múltiplos. No plano longitudinal tangencial os raios são invisíveis mesmo sob lente de 10x, linhas vasculares retilíneas. No plano longitudinal radial o espelhado dos raios é pouco contrastado. Camadas de crescimento distintas individualizadas pelo parênquima marginal.

Descrição microscópica

Vasos com porosidade difusa, arranjo diagonal, múltiplos na maioria, em cadeias radiais e em forma de cacho, forma da secção arredondada, placas de perfuração simples, diâmetro tangencial de $39,1 \mu \mathrm{m}$, elementos vasculares com 0,188 $\mathrm{mm}$ de comprimento, com nenhum, 1 ou 2 apêndices, tilos não abundantes, depósitos em vasos de cor marrom claro, pontoações intervasculares alternas, arredondadas e do tipo escalariforme também, com diâmetro tangencial de 4,2 $\mu \mathrm{m}$, pontoações radiovasculares semelhantes æ̀s intervasculares. Parênquima axial vasicêntrico e em linhas marginais. Fibras com $0,97 \mathrm{~mm}$ de comprimento e paredes delgadas a espessas. Raios uni, bi e trisseriados, com $0,179 \mathrm{~mm}$ de altura, homocelulares com todas as células procumbentes. Camadas de crescimento também individualizadas pela variação do lume das fibras. 


\section{PAINEIRA - Chorisia speciosa $\quad$ FIGURA n ${ }^{\circ} 21$}

Descrição dos caracteres gerais

Madeira com cerne e alburno indistintos pela cor, o cerne com coloração bege claro, brilho, odor imperceptível, macia ao corte manual no plano transversal, grã direita, textura média e camadas de crescimento distintas.

Descrição macroscópica

Parênquima axial visível somente sob lente de 10x, paratraqueal vasicêntrico. Raios visíveis a olho nu, médios, poucos. Poros visíveis a olho nu, médios a grandes, pouco numerosos, com porosidade difusa, solitários na maioria. No plano longitudinal angencial os raios são visíveis somente sob lente de 10x, baixos, linhas vasculares retilíneas. No plano longitudinal radial o espelhado dos raios é contrastado. Camadas de crescimento distintas individualizadas por zonas fibrosas tangenciais mais escuras.

Descrição microscópica

Vasos com porosidade difusa, arranjo tangencial, solitários e múltiplos, forma da secção arredondada, placas de perfuração simples, com diâmetro tangencial de $208,8 \mu \mathrm{m}$, elementos vasculares com comprimento de $0,39 \mathrm{~mm}$, ausência de apêndices, tilos não abundantes, pontoações intervasculares alternas, arredondadas, com diâmetro tangencial de 13,6 $\mu \mathrm{m}$, pontoações radiovasculares semelhantes æ̀̀ intervasculares. Parênquima axial vasicêntrico, difuso e em faixas. Fibras com 1,79 mm de comprimento e paredes delgadas a espessas. Raios multisseriados na maioria, com altura de 0,949 mm, homocelulares com todas as células procumbentes. Camadas de crescimento individualizadas pela variação do lume das fibras. 
TANHEIRO - Alchorena sidifolia

FIGURA $n^{\circ} 22$

Descrição dos caracteres gerais

Madeira com cerne e alburno indistintos pela cor, o cerne com coloração castanho alaranjado, com brilho moderado, odor imperceptível, moderadamente dura ao corte manual no plano transversal, grã direita, textura média e camadas de crescimento distintas.

Descrição macroscópica

Parênquima axial visível somente sob lente de 10x, paratraqueal aliforme de extensão linear. Raios visíveis somente sob lente de 10x, finos, numerosos. Poros visíveis somente sob lente de 10x, pequenos, poucos, porosidade difusa, solitários e múltiplos. No plano longitudinal tangencial os raios são invisíveis mesmo sob lente de 10x, linhas vasculares retilíneas. No plano longitudinal radial o espelhado dos raios é pouco contrastado. Camadas de crescimento distintas individualizadas por zonas fibrosas tangenciais mais escuras.

Descrição microscópica

Vasos com porosidade difusa, arranjo tangencial, solitários e múltiplos em pequenas cadeias radiais ( 2 a 4 células), forma da secção arredondada, placas de perfuração simples, diâmetro tangencial de $120,9 \mu \mathrm{m}$, elementos vasculares com comprimento de 0,53 mm, presença de 1 apêndice, tilos não abundantes, pontoações intervasculares alternas, arredondadas, com diâmetro tangencial de 12,2 $\mu \mathrm{m}$, pontoações radiovasculares semelhantes æ̀s intervasculares mas maiores. Parênquima axial difuso em agregados e paratraqueal aliforme linear. Fibras com 1,18 mm de comprimento e paredes delgadas a espessas. Raios unisseriados, com $0,482 \mathrm{~mm}$ de altura, homocelulares com todas as células quadradas. $\underline{\text { Cristais }}$ presentes em células do parênquima radial. Camadas de crescimento também individualizadas pelo achatamento do lume das fibras. 
AROEIRA-VERMELHA - Schinus terebinthifolius

FIGURA $n^{\circ} 23$

Descrição dos caracteres gerais

Madeira com cerne e alburno distintos pela cor, sendo o cerne castanho avermelhado e o alburno bege-róseo, sem brilho, odor imperceptível, moderadamente dura ao corte manual no plano transversal, grã direita, textura média e camadas de crescimento indistintas.

Descrição macroscópica

Parênquima axial invisível mesmo sob lente de 10x. Raios visíveis somente sob lente de 10x, finos, pouco numerosos. Poros visíveis somente sob lente de 10x, pequenos, muito numerosos, porosidade difusa, solitários e múltiplos. No plano longitudinal tangencial os raios são invisíveis mesmo sob lente de 10x, linhas vasculares retilíneas. No plano longitudinal radial o espelhado dos raios é pouco contrastado.

Descrição microscópica

Vasos com porosidade difusa, arranjo tangencial, múltiplos na maioria, forma da secção arredondada, placas de perfuração simples, com diâmetro tangencial de $56,6 \mu \mathrm{m}$, elementos vasculares com $0,38 \mathrm{~mm}$ de comprimento, nenhum, 1 ou 2 apêndices, tilos não abundantes, pontoações intervasculares alternas, arredondadas, œm diâmetro tangencial de 5,7 $\mu \mathrm{m}$, pontoações radiovasculares semelhantes æ̀̀ intervasculares. Parênquima axial difuso. Fibras com 0,77 mm de comprimento e paredes delgadas a espessas. Raios bisseriados na maioria, com altura de 0,242 mm, heterocelulares, com células procumbentes e 1 a 2 fileiras marginais de células quadradas. Cristais presentes em células do parênquima radial. 
UNHA-DE-VACA - Bauhinia forficata

FIGURA $n^{\circ} 24$

Descrição dos caracteres gerais

Madeira com cerne e alburno distintos pela cor, sendo o cerne castanho avermelhado e o alburno castanho-claro, com brilho moderado, odor imperceptível, moderadamente dura ao corte manual no plano transversal, grã revessa, textura média e camadas de crescimento distintas.

Descrição macroscópica

Parênquima axial visível a olho nu, paratraqueal vasicêntrico e em linhas marginais. Raios visíveis a olho nu, médios, poucos. Poros visíveis a olho nu, médios, numerosos, porosidade difusa, múltiplos na maioria, camadas de crescimento distintas individualizadas pelo parênquima marginal. No plano longitudinal tangencial os raios são visíveis somente sob lente de 10x, altos, linhas vasculares retilíneas. No plano longitudinal radial o espelhado dos raios é contrastado.

Descrição microscópica

Vasos com porosidade difusa, arranjo tangencial, solitários e múltiplos, forma da secção arredondada, placas de perfuração simples, diâmetro tangencial de $156,2 \mu \mathrm{m}$, elementos vasculares com $0,54 \mathrm{~mm}$ de comprimento, nenhum ou 1 apêndice, tilos abundantes, pontoações intervasculares alternas, arredondadas, com diâmetro tangencial de 8,1 $\mu \mathrm{m}$, pontoações radiovasculares semelhantes às intervasculares mas maiores. Parênquima axial vasicêntrico e em linhas marginais. Fibras com $1,23 \mathrm{~mm}$ de comprimento e paredes delgadas a espessas. Raios bi e trisseriados, com altura de 0,61 mm, heterocelulares, com células procumbentes e 1 fileira marginal de células quadradas. Cristais presentes em células do parênquima axial. 


\section{CARAPOROCA - Rapanea umbellata FIGURA n² 25}

Descrição dos caracteres gerais

Madeira com cerne e alburno indistintos pela cor, o cerne com coloração castanho avermelhado, sem brilho, odor imperceptível, macia ao corte manual no plano transversal, grã direita, textura média e camadas de crescimento pouco distintas.

Descrição macroscópica

Parênquima axial invisível mesmo sob lente de 10x. Raios visíveis a olho nu, largos, poucos. Poros visíveis somente sob lente de 10x, pequenos, numerosos, porosidade difusa, múltiplos na maioria. No plano longitudinal tangencial os raios são visíveis a olho nu, altos, linhas vasculares retilíneas. No plano longitudinal radial o espelhado dos raios é pouco contrastado. Camadas de crescimento distintas individualizadas por zonas fibrosas tangenciais mais escuras.

Descrição microscópica

Vasos com porosidade difusa, arranjo tangencial, múltiplos na maioria, forma da secção arredondada, placas de perfuração simples, diâmetro tangencial de 166,6 $\mu \mathrm{m}$, elementos vasculares com 0,27 mm, nenhum ou 1 apêndice, tilos não abundantes, pontoações intervasculares alternas, arredondadas, com diâmetro tangencial de 4,6 $\mu \mathrm{m}$, pontoações radiovasculares semelhantes æ̀s intervasculares mas maiores. Parênquima axial difuso. Fibras com comprimento de 0,83 $\mathrm{mm}$ e paredes delgadas a espessas. Raios multisseriados, com altura de $3,02 \mathrm{~mm}$, homocelulares, com todas as células quadradas. $\underline{\text { Cristais presentes }}$ em células do parênquima radial. Amadas de crescimento individualizadas pela variação do lume das fibras. 
PITANGUEIRA - Eugenia uniflora

FIGURA n 26

Descrição dos caracteres gerais

Madeira com cerne e alburno indistintos pela cor, o cerne com coloração castanho escuro, sem brilho, odor imperceptível, dura ao corte manual no plano transversal, grã direita, textura fina e camadas de crescimento pouco distintas.

Descrição macroscópica

Parênquima axial visível a olho nu, apotraqueal em linhas marginais. Raios visíveis somente sob lente de $10 \mathrm{x}$, finos, poucos. Poros visíveis somente sob lente de 10x, pequenos, muito numerosos, porosidade difusa, solitários e múltiplos. No plano longitudinal tangencial os raios são invisíveis mesmo sob lente de 10x, linhas vasculares retilíneas. No plano longitudinal radial o espelhado dos raios é pouco contrastado. Camadas de crescimento distintas individualizadas por zonas fibrosas tangenciais mais escuras.

Descrição microscópica

Vasos com porosidade difusa, arranjo tangencial, solitários, forma da secção arredondada, placas de perfuração simples, com diâmetro tangencial de 43,3 $\mu \mathrm{m}$, elemento vascular com comprimento de $0,20 \mathrm{~mm}$, nenhum ou 2 apêndices, tilos não abundantes, depósitos nos vasos pouco abundante de cor marrom, pontoações intervasculares opostas, arredondadas, com diâmetro tangencial de 2,8 $\mu \mathrm{m}$, pontoações radiovasculares semelhantes æ̀s intervasculares mas menores. $\underline{\text { Parênquima axial difuso em agregados, e em linhas marginais. Fibras }}$ com comprimento de $0,77 \mathrm{~mm}$ e paredes muito espessas. Raios uni e bisseriados, com altura de 0,223 $\mathrm{mm}$, homocelulares, com todas as células procumbentes. Cristais presentes em células do parênquima axial e radial. Camadas de crescimento também individualizadas pela variação do lume das fibras. 
CAPITÃO-DO-CAMPO - Terminalia brasiliensis

FIGURA $n^{\circ} 27$

Descrição dos caracteres gerais

Madeira com cerne e alburno indistintos pela cor, o cerne com coloração pardoclaro, sem brilho, odor imperceptível, dura ao corte manual no plano transversal, grã direita, textura média e camadas de crescimento distintas.

Descrição macroscópica

Parênquima axial visível a olho nu, predominantemente paratraqueal aliforme losangular, difuso, vasicêntrico escasso e marginal em linhas finas. Raios visíveis somente sob lente de 10x, finos, poucos. Poros visíveis a olho nu, pequenos a médios, pouco numerosos, porosidade difusa, solitários e múltiplos. No plano longitudinal tangencial os raios são invisíveis mesmo sob lente de 10x, linhas vasculares retilíneas. No plano longitudinal radial o espelhado dos raios é pouco contrastado. Camadas de crescimento distintas individualizadas por zonas fibrosas tangenciais mais escuras e pelas linhas do parênquima marginal.

Descrição microscópica

Vasos com porosidade difusa, arranjo tangencial, solitários e múltiplos na maioria em cadeias radiais de 2 a 5 vasos, forma da secção arredondada, placas de perfuração simples, com diâmetro tangencial de $141 \mu \mathrm{m}$, elemento vascular com comprimento de 0,59 mm, nenhum ou 1 apêndice, tilos não abundantes, pontoações intervasculares alternas, arredondadas, com diâmetro tangencial de 8,2 $\mu \mathrm{m}$, pontoações radiovasculares semelhantes às intervasculares. Parênquima axial vasicêntrico escasso, aliforme confluente e em linhas marginais. Fibras septadas, com comprimento de $1,47 \mathrm{~mm}$ e paredes delgadas a espessas. Raios a maioria unisseriados com raros bisseriados, com altura de $0,43 \mathrm{~mm}$, homocelulares, com todas as células procumbentes. $\underline{\text { Cristais }}$ presentes em células do parênquima radial. Camadas de crescimento individualizadas pelo achatamento do lume das fibras. 
JATOBÁ - Hymenaea courbaril FIGURA nº 28

Descrição dos caracteres gerais

Madeira com cerne e alburno distintos pela cor, sendo o alburno com coloração amarelada e o cerne castanho-avermelhado, sem brilho, odor imperceptível, moderadamente dura ao corte manual no plano transversal, grã direita, textura média e camadas de crescimento distintas.

Descrição macroscópica

Parênquima axial visível a olho nu em linhas marginais, e aliforme ou vasicêntrico escasso visível somente sob lente de 10x. Raios visíveis a olho nu, médios, poucos. Poros visíveis a olho nu, médios a grandes, pouco numerosos, porosidade difusa, solitários e múltiplos, obstruídos por óleo-resina. No plano longitudinal tangencial os raios são visíveis a olho nu, linhas vasculares retilíneas. No plano longitudinal radial o espelhado dos raios é pouco contrastado. Camadas de crescimento distintas individualizadas pelas linhas do parênquima marginal.

Descrição microscópica

Vasos com porosidade difusa, arranjo tangencial, solitários na maioria, forma da secção arredondada, placas de perfuração simples, com diâmetro tangencial de $139 \mu \mathrm{m}$, elemento vascular com comprimento de $0,54 \mathrm{~mm}$, nenhum ou 1 apêndice, tilos não abundantes, depósitos nos vasos abundante de cor marrom, pontoações intervasculares alternas, arredondadas, guarnecidas, com diâmetro tangencial de $9 \mu \mathrm{m}$, pontoações radiovasculares semelhantes ’̀s intervasculares. Parênquima axial aliforme confluente e em linhas marginais. Fibras com comprimento de $1,55 \mathrm{~mm}$ e paredes delgadas a espessas. Raios multisseriados na maioria e alguns tri e bisseriados, com altura de 0,6 mm, homocelulares, com todas as células procumbentes. Cristais presentes em células do parênquima axial. Camadas de crescimento individualizadas pelo parênquima marginal. 
IPÊ-AMARELO - Tabebuia chrysotricha

FIGURA $n^{\circ} 29$

Descrição dos caracteres gerais

Madeira com cerne e alburno indistintos pela cor, o cerne com coloração pardoclaro, sem brilho, odor imperceptível, moderadamente dura ao corte manual no plano transversal, grã direita, textura fina e camadas de crescimento distintas.

Descrição macroscópica

Parênquima axial visível somente sob lente de 10x, vasicêntrico ou aliforme formando confluências e em linhas marginais. Raios visíveis somente sob lente de 10x, finos, numerosos. Poros pouco visíveis a olho nu, pequenos, pouco numerosos, porosidade difusa, solitários na maioria, obstruídos por ipeína. No plano longitudinal tangencial os raios são visíveis somente sob lente de 10x, estratificados, linhas vasculares retilíneas. No plano longitudinal radial o espelhado dos raios é pouco contrastado. Camadas de crescimento distintas individualizadas por zonas fibrosas tangenciais mais escuras e pelas linhas do parênquima marginal.

Descrição microscópica

Vasos com porosidade difusa, arranjo tangencial, solitários e múltiplos, forma da secção arredondada, placas de perfuração simples, com diâmetro tangencial de $90 \mu \mathrm{m}$, elemento vascular com comprimento de $.0,24 \mathrm{~mm}$, sem apêndices, tilos não abundantes, pontoações intervasculares alternas, arredondadas, com diâmetro tangencial de 5,8 $\mu \mathrm{m}$, pontoações radiovasculares semelhantes æ̀s intervasculares. Parênquima axial aliforme confluente. Fibras com comprimento de $0.87 \mathrm{~mm}$ e paredes muito espessas. Raios bisseriados na maioria e alguns unisseriados, com altura de 0,16 mm, homocelulares, com todas as células procumbentes, estratificados. Camadas de crescimento demarcadas pela variação do lume das fibras. 
GUATAMBU - Aspidosperma ramiflorum

FIGURA $n^{\circ} 30$

Descrição dos caracteres gerais

Madeira com cerne e alburno indistintos pela cor, o cerne com coloração amarelada, sem brilho, odor imperceptível, moderadamente dura ao corte manual no plano transversal, grã direita, textura fina e camadas de crescimento distintas.

Descrição macroscópica

Parênquima axial visível somente sob lente de 10x, marginal em faixas finas. Raios visíveis somente sob lente de 10x, finos, numerosos. Poros visíveis somente sob lente de 10x, muito pequenos, muito numerosos, porosidade difusa, solitários na maioria. No plano longitudinal tangencial os raios são visíveis somente sob lente de $10 \mathrm{x}$, linhas vasculares retilíneas. No plano longitudinal radial o espelhado dos raios é pouco contrastado. Camadas de crescimento distintas individualizadas pelo parênquima marginal.

Descrição microscópica

Vasos com porosidade em anéis porosos, solitários na grande maioria, forma da secção arredondada, placas de perfuração simples, com diâmetro tangencial de $68 \mu \mathrm{m}$, elemento vascular com comprimento de $0,87 \mathrm{~mm}, 1$ ou 2 apêndices, tilos não abundantes, pontoações intervasculares alternas, arredondadas, com diâmetro tangencial de 6,1 $\mu \mathrm{m}$, pontoações radiovasculares semelhantes æ̀ intervasculares. Parênquima axial difuso e marginal. Fibras com comprimento de $1,37 \mathrm{~mm}$ e paredes delgadas a espessas. Raios bisseriados na maioria e alguns unisseriados, com altura de 0,24 mm, homocelulares, com todas as células procumbentes. Presença de cristais nas células do parênquima axial. Camadas de crescimento demarcadas também pela presença de anéis porosos. 
GUARITÁ - Astronium graveolens

FIGURA $n^{\circ} 31$

Descrição dos caracteres gerais

Madeira com cerne e alburno indistintos pela cor, o cerne com coloração begeamarelado, sem brilho, odor imperceptível, moderadamente dura ao corte manual no plano transversal, grã direita, textura fina e camadas de crescimento indistintas.

Descrição macroscópica

Parênquima axial invisível mesmo sob lente de 10x. Raios visíveis somente sob lente de 10x, finos, numerosos. Poros visíveis somente sob lente de 10x, pequenos, pouco numerosos, porosidade difusa, solitários e múltiplos. No plano longitudinal tangencial os raios são visíveis somente sob lente de 10x, linhas vasculares retilíneas. No plano longitudinal radial o espelhado dos raios é pouco contrastado.

Descrição microscópica

Vasos com porosidade difusa, arranjo tangencial, solitários e múltiplos, forma da secção arredondada, placas de perfuração simples, com diâmetro tangencial de $193 \mu \mathrm{m}$, elemento vascular com comprimento de 0,59 mm, 1 apêndice, tilos abundantes, pontoações intervasculares alternas, arredondadas, com diâmetro tangencial de 9,5 $\mu \mathrm{m}$, pontoações radiovasculares semelhantes ìs intervasculares. Parênquima axial vasicêntrico escasso. Fibras com comprimento de $1,09 \mathrm{~mm}$ e paredes delgadas a espessas. Raios uni, bi e trisseriados, com altura de $0,41 \mathrm{~mm}$, heterocelulares, com células procumbentes e 1 a 3 fileiras marginais de células quadradas. Cristais presentes em células do parênquima axial e radial. Sílica presente no parênquima radial. Camadas de crescimento demarcadas pelo achatamento do lume das fibras. 
CHÁ-DE-BUGRE - Cordia sellowiana FIGURA no 32

Descrição dos caracteres gerais

Madeira com cerne e alburno indistintos pela cor, o cerne com coloração castanha, sem brilho, odor imperceptível, moderadamente dura ao corte manual no plano transversal, grã direita, textura fina e camadas de crescimento distintas.

Descrição macroscópica

Parênquima axial visível a olho nu aliforme e aliforme confluente. Raios visíveis a olho nu, médios, numerosos. Poros visíveis a olho nu, pequenos, pouco numerosos, porosidade difusa, solitários e múltiplos na maioria. No plano longitudinal tangencial os raios são visíveis a olho nu, altos, Inhas vasculares retilíneas. No plano longitudinal radial o espelhado dos raios é contrastado. Camadas de crescimento distintas individualizadas por zonas fibrosas tangenciais mais escuras.

Descrição microscópica

Vasos com porosidade difusa, arranjo tangencial, múltiplos na maioria, forma da secção arredondada, placas de perfuração simples, com diâmetro tangencial de $206 \mu \mathrm{m}$, elemento vascular com comprimento de $0,29 \mathrm{~mm}$, nenhum ou 1 apêndice, tilos não abundantes, pontoações intervasculares alternas, arredondadas, com diâmetro tangencial de 9,6 $\mu \mathrm{m}$, pontoações radiovasculares semelhantes às intervasculares. Parênquima axial aliforme e aliforme confluente formando faixas. Fibras com comprimento de $1,33 \mathrm{~mm}$ e paredes delgadas a espessas. Raios multisseriados, com altura de $1,01 \mathrm{~mm}$, heterocelulares, com células procumbentes e 1 a 2 fileiras marginais de células quadradas. Camadas de crescimento demarcadas pela variação do lume das fibras. 


\section{EMBIRUÇU - Bombax grandiflorum}

FIGURA $n^{\circ} 33$

Descrição dos caracteres gerais

Madeira com cerne e alburno indistintos pela cor, o cerne com coloração castanho escuro, sem brilho, odor imperceptível, macia ao corte manual no plano transversal, grã direita, textura média e camadas de crescimento distintas. Descrição macroscópica

Parênquima axial visível a olho nu em linhas marginais e somente sob lente de 10x, difuso em agregados. Raios visíveis a olho nu, médios, pouco numerosos. Poros visíveis a olho nu, médios, poucos, porosidade difusa, solitários e múltiplos em cadeias radiais de 2 a 4 . No plano longitudinal tangencial os raios são visíveis a olho nu, altos, linhas vasculares retilíneas. No plano longitudinal radial o espelhado dos raios é pouco contrastado. Camadas de crescimento individualizadas pelas linhas de parênquima marginal.

Descrição microscópica

Vasos com porosidade difusa, arranjo tangencial, múltiplos na maioria em cadeias radiais de 2 a 5 vasos, forma da secção arredondada, placas de perfuração simples, com diâmetro tangencial de $279 \mu \mathrm{m}$, elemento vascular com comprimento de 0,44 mm, nenhum ou 1 apêndice, tilos pouco abundantes, pontoações intervasculares alternas, arredondadas, com diâmetro tangencial de 14,4 $\mu \mathrm{m}$, pontoações radiovasculares semelhantes æ̀ intervasculares. Parênquima axial difuso em agregados e em faixas marginais. Fibras com comprimento de 2,61 $\mathrm{mm}$ e paredes delgadas a espessas. Raios multisseriados, com altura de $1,23 \mathrm{~mm}$, heterocelulares, onde misturam-se células procumbentes e células quadradas. Cristais presentes em células do parênquima axial e radial. Sílica presente no parênquima radial. $\underline{\text { Camadas de }}$ crescimento individualizadas pelo parênquima marginal. 
PEROBA-POCA - Aspidosperma cylindrocarpon

FIGURA $n^{\circ} 34$

Descrição dos caracteres gerais

Madeira com cerne e alburno indistintos pela cor, o cerne com coloração bege, sem brilho, odor imperceptível, macia ao corte manual no plano transversal, grã direita, textura fina e camadas de crescimento distintas.

Descrição macroscópica

Parênquima axial visível somente sob lente de 10x,em linhas marginais. Raios visíveis somente sob lente de 10x, finos, numerosos. Poros visíveis somente sob lente de 10x, pequenos, numerosos, porosidade difusa, solitários na maioria. No plano longitudinal tangencial os raios são visíveis somente sob lente de 10x, baixos, linhas vasculares retilíneas. No plano longitudinal radial o espelhado dos raios é pouco contrastado. Camadas de crescimento individualizadas pelas linhas de parênquima marginal e por zonas fibrosas tangenciais mais escuras.

Descrição microscópica

Vasos com porosidade difusa, arranjo tangencial, solitários na maioria, forma da secção arredondada, placas de perfuração simples, com diâmetro tangencial de $98 \mu \mathrm{m}$, elemento vascular com comprimento de $0,50 \mathrm{~mm}$, nenhum, 1 ou 2 apêndices, tilos não abundantes, pontoações intervasculares alternas, arredondadas, com diâmetro tangencial de 3,8 $\mu \mathrm{m}$, pontoações radiovasculares semelhantes æ̀̀ intervasculares. Parênquima axial difuso. Fibras com comprimento de $1,33 \mathrm{~mm}$ e paredes delgadas a espessas. Raios trisseriados na maioria e alguns bisseriados, com altura de $0,27 \mathrm{~mm}$, homocelulares, com todas as células procumbentes. Cristais presentes cristais em células do parênquima axial e radial. Camadas de crescimento individualizadas pelo parênquima marginal e pela variação do lume das fibras. 
CANJARANA - Cabralea canjerana

FIGURA $n^{\circ} 35$

Descrição dos caracteres gerais

Madeira com cerne e alburno indistintos pela cor, com coloração vermelho escuro, sem brilho, odor imperceptível, moderadamente dura ao corte manual no plano transversal, grã direita, textura média e camadas de crescimento indistintas.

\section{Descrição macroscópica}

Parênquima axial visível somente sob lente de 10x em faixas longas envolvendo ou ligando os poros. Raios visíveis somente sob lente de 10x, finos, poucos. Poros visíveis a olho nu, médios, poucos, porosidade difusa, solitários e múltiplos, obstruídos por substância branca. No plano longitudinal tangencial os raios são invisíveis mesmo sob lente de 10x, linhas vasculares retilíneas. No plano longitudinal radial o espelhado dos raios é pouco contrastado.

Descrição microscópica

Vasos com porosidade difusa, solitários e múltiplos, forma da secção arredondada a ovalada, placas de perfuração simples, diâmetro tangencial de $246 \mu \mathrm{m}$, elemento vascular com comprimento de $0,75 \mathrm{~mm}$, nenhum ou 2 apêndices, tilos não abundantes, depósitos de cor marrom abundante, pontoações intervasculares alternas, arredondadas, com diâmetro tangencial de 4,6 $\mu \mathrm{m}$, pontoações radiovasculares semelhantes æ̀̀ intervasculares mas menores. Parênquima axial em faixas. Fibras septadas, com comprimento de $1,76 \mathrm{~mm}$ e paredes delgadas a espessas. Raios bisseriados na maioria e alguns unisseriados, com altura de $0,68 \mathrm{~mm}$, heterocelulares, com células procumbentes e uma fileira marginal de células quadradas. 
BICO-DE-PATO - Machaerium aculeatum

FIGURA $n^{\circ} 36$

Descrição dos caracteres gerais

Madeira com cerne e alburno indistintos pela cor, com coloração castanha, sem brilho, odor imperceptível, moderadamente dura ao corte manual no plano transversal, grã direita, textura média e camadas de crescimento indistintas.

Descrição macroscópica

Parênquima axial visível somente sob lente de 10x, aliforme linear com algumas confluências. Raios visíveis somente sob lente de 10x, finos, poucos. Poros visíveis a olho nu, médios, poucos, porosidade difusa, solitários na maioria. No plano longitudinal tangencial os raios são visíveis somente sob lente de 10x, estratificados, baixos, linhas vasculares retilíneas. No plano longitudinal radial o espelhado dos raios é pouco contrastado.

Descrição microscópica

Vasos com porosidade difusa, solitários na maioria, forma da secção arredondada, placas de perfuração simples, diâmetro tangencial de $186 \mu \mathrm{m}$, elemento vascular com comprimento de 0,21 mm, ausência de apêndices, tilos não abundantes, depósitos de cor marrom claro pouco abundante, pontoações intervasculares alternas, arredondadas, com diâmetro tangencial de 8,2 $\mu \mathrm{m}$, pontoações radiovasculares semelhantes æ̀s intervasculares mas menores. Parênquima axial aliforme linear confluente. Fibras com comprimento de 0,83 $\mathrm{mm}$ e paredes delgadas. Raios uni e bisseriados, com altura de 0,23 mm, heterocelulares, com células procumbentes e 1 a 4 fileiras marginais de células quadradas. $\underline{\text { Cristais }}$ presentes em células do parênquima axial e nas fibras. 
GUAICÁ - Ocotea puberula

FIGURA $n^{\circ} 37$

Descrição dos caracteres gerais

Madeira com cerne e alburno indistintos pela cor, com coloração pardo acastanhado, sem brilho, odor imperceptível, moderadamente dura ao corte manual no plano transversal, grã direita, textura média e camadas de crescimento pouco distintas.

Descrição macroscópica

Parênquima axial invisível mesmo sob lente de 10x. Raios visíveis somente sob lente de 10x, finos a médios, poucos. Poros visíveis somente sob lente de 10x, médios, poucos, porosidade difusa, solitários e múltiplos em cadeias radiais de 2 a 8, obstruídos por tilos. No plano longitudinal tangencial os raios são invisíveis mesmo sob lente de 10x, linhas vasculares retilíneas. No plano longitudinal radial o espelhado dos raios é contrastado. Camadas de crescimento individualizadas por zonas fibrosas tangenciais mais escuras.

Descrição microscópica

Vasos com porosidade difusa, solitários e múltiplos, forma da secção arredondada, placas de perfuração simples, diâmetro tangencial de $199 \mu \mathrm{m}$, elemento vascular com comprimento de $0,78 \mathrm{~mm}$, nenhum, 1 ou 2 apêndices, tilos não abundantes, pontoações intervasculares alternas, arredondadas, guarnecidas, com diâmetro tangencial de 10,6 $\mu \mathrm{m}$, pontoações radiovasculares semelhantes æ̀ intervasculares mas não guarnecidas. Parênquima axial escasso difuso. Fibras septadas com comprimento de $1,34 \mathrm{~mm}$ e paredes delgadas a espessas. Raios bi e trisseriados, com altura de 0,56 mm, homocelulares, com todas as células procumbentes. Camadas de crescimento demarcadas pelo achatamento do lume das fibras. 
CAPIXINGUI - Croton sp. FIGURA n $n^{\circ} 38$

Descrição dos caracteres gerais

Madeira com cerne e alburno pouco distintos pela cor, sendo o cerne com coloração bege amarelada e o alburno um pouco mais claro, brilho moderado, odor imperceptível, moderadamente dura ao corte manual no plano transversal, grã direita, textura fina e camadas de crescimento pouco distintas.

Descrição macroscópica

Parênquima axial visível somente sob lente de 10x, em linhas regulares, formando um reticulado com os raios. Raios visíveis somente sob lente de 10x, finos, numerosos. Poros visíveis somente sob lente de 10x, pequenos a médios, numerosos, porosidade difusa, solitários na maioria e alguns múltiplos em cadeias radiais de 2 a 4, alguns obstruídos por substância branca. No plano longitudinal tangencial os raios são invisíveis mesmo sob lente de 10x, linhas vasculares retilíneas. No plano longitudinal radial o espelhado dos raios é contrastado. Camadas de crescimento distintas individualizadas por zonas fibrosas tangenciais mais escuras.

Descrição microscópica

Vasos com porosidade difusa, solitários e múltiplos, forma da secção arredondada a ovalada, placas de perfuração simples, diâmetro tangencial de $133 \mu \mathrm{m}$, elemento vascular com comprimento de $0,78 \mathrm{~mm}, 1$ apêndice, tilos não abundantes, pontoações intervasculares alternas, arredondadas, com diâmetro tangencial de 11,5 $\mu \mathrm{m}$, pontoações radiovasculares semelhantes æ̀s intervasculares. Parênquima axial em linhas finas ligando os poros. Fibras com comprimento de $1,48 \mathrm{~mm}$ e paredes delgadas a espessas. Raios uni e bisseriados, com altura de $0,51 \mathrm{~mm}$, heterocelulares, onde se misturam células procumbentes e quadradas. Cristais presentes em células do parênquima axial. Camadas de crescimento demarcadas pela variação do lume das fibras. 
MUTAMBO - Guazuma ulmifolia

FGURA n 39

Descrição dos caracteres gerais

Madeira com cerne e alburno indistintos pela cor, com coloração bege escuro, brilho moderado, odor imperceptível, moderadamente dura ao corte manual no plano transversal, grã direita, textura média e camadas de crescimento pouco distintas.

Descrição macroscópica

Parênquima axial invisível mesmo sob lente de 10x. Raios visíveis a olho nu, médios, poucos. Poros visíveis a olho nu, médios, poucos, porosidade difusa, solitários e múltiplos. No plano longitudinal tangencial os raios são visíveis a olho nu, altos, linhas vasculares retilíneas. No plano longitudinal radial o espelhado dos raios é pouco contrastado. Camadas de crescimento individualizadas por zonas fibrosas tangenciais mais escuras.

\section{Descrição microscópica}

Vasos com porosidade difusa, solitários e múltiplos, forma da secção arredondada, placas de perfuração simples, diâmetro tangencial de $149 \mu \mathrm{m}$, elemento vascular com comprimento de $0,37 \mathrm{~mm}$, nenhum ou 2 apêndices, tilos não abundantes, pontoações intervasculares alternas, arredondadas, com diâmetro tangencial de 3,19 $\mu \mathrm{m}$, pontoações radiovasculares semelhantes æ̀̀ intervasculares. Parênquima axial difuso em agregados. Fibras com comprimento de $1,69 \mathrm{~mm}$ e paredes delgadas a espessas. Raios uni a multisseriados, com altura de $0,59 \mathrm{~mm}$, heterocelulares, onde se misturam células procumbentes e quadradas. Cristais presentes em células do parênquima axial. Camadas de crescimento demarcadas pela variação do lume das fibras. 
MAMICA-DE-PORCA - Zanthoxylum rhoifolium

FIGURA $n^{\circ} 40$

Descrição dos caracteres gerais

Madeira com cerne e alburno indistintos pela cor, com coloração bege esverdeado, sem brilho, odor imperceptível, moderadamente dura ao corte manual no plano transversal, grã direita, textura fina e camadas de crescimento pouco distintas.

Descrição macroscópica

Parênquima axial invisível mesmo sob lente de 10x. Raios visíveis somente sob lente de 10X, finos, muito poucos. Poros visíveis somente sob lente de 10x, pequenos, numerosos, porosidade difusa, solitários e múltiplos, alguns obstruídos por substância branca. No plano longitudinal tangencial os raios são invisíveis mesmo sob lente de 10x, linhas vasculares retilíneas. No plano longitudinal radial o espelhado dos raios é pouco contrastado. Camadas de crescimento individualizadas por zonas fibrosas tangenciais mais escuras.

Descrição microscópica

Vasos com porosidade difusa, solitários e múltiplos, forma da secção arredondada, placas de perfuração simples, diâmetro tangencial de $81 \mu \mathrm{m}$, elemento vascular com comprimento de $0,37 \mathrm{~mm}$, nenhum, 1 ou 2 apêndices, tilos não abundantes, pontoações intervasculares alternas, arredondadas, com diâmetro tangencial de 5,7 $\mu \mathrm{m}$, pontoações radiovasculares semelhantes às intervasculares. Parênquima axial paratraqueal vasicêntrico escasso. Fibras com comprimento de $0,94 \mathrm{~mm}$ e paredes delgadas a espessas. Raios bi e trisseriados, raros unisseriados, com altura de 0,28 mm, heterocelulares com células procumbentes e 1 a 2 fileiras marginais de células quadradas. Camadas de crescimento demarcadas pelo achatamento do lume das fibras. 
CANDIÚBA - Trema micrantha

FIGURA $n^{\circ} 41$

Descrição dos caracteres gerais

Madeira com cerne e alburno indistintos pela cor, com coloração bege acastanhado, com brilho moderado, odor imperceptível, moderadamente dura ao corte manual no plano transversal, grã direita, textura fina e camadas de crescimento pouco distintas.

Descrição macroscópica

Parênquima axial invisível mesmo sob lente de 10x. Raios visíveis somente sob lente de 10x, finos, muito poucos. Poros visíveis somente sob lente de 10x, pequenos, poucos, porosidade difusa, solitários na maioria. No plano longitudinal tangencial os raios são invisíveis mesmo sob lente de 10x, linhas vasculares retilíneas. No plano longitudinal radial o espelhado dos raios é pouco contrastado. Camadas de crescimento individualizadas por zonas fibrosas tangenciais mais escuras.

Descrição microscópica

Vasos com porosidade difusa, solitários na maioria, forma da secção arredondada, placas de perfuração simples, diâmetro tangencial de $84 \mu \mathrm{m}$, elemento vascular com comprimento de 0,27 mm, nenhum, 1 ou 2 apêndices, tilos não abundantes, pontoações intervasculares alternas, poligonais, com diâmetro tangencial de 9,3 $\mu \mathrm{m}$, pontoações radiovasculares semelhantes às intervasculares. Parênquima axial paratraqueal vasicêntrico escasso. Fibras com comprimento de 0,93 $\mathrm{mm}$ e paredes delgadas a espessas. Raios uni, bi e trisseriados, com altura de $0,50 \mathrm{~mm}$, homocelulares com todas as células quadradas. Camadas de crescimento demarcadas pela variação do lume das fibras. 


\subsection{Chave para identificação macroscópica das espécies selecionadas através de suas madeiras (método tradicional):}

Com base na descrição da estrutura macroscópica da madeira foi elaborada uma chave de identificação das diferentes espécies florestais. Essa chave permite a identificação expedita das espécies em condições de campo e de laboratório a partir do plimento das seções da madeira, principalmente da transversal, e o seu exame com auxílio de lupa de 10x.

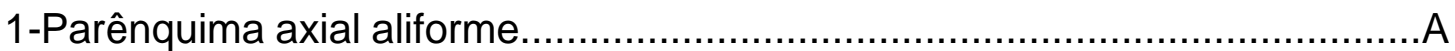

2-Parênquima axial em linhas ou faixas estreitas ligando os poros...................B

3-Parênquima axial em linhas finas formando um retículo com os raios............

4-Parênquma axial vasicêntrico ou vasicêntrico escasso...................................D

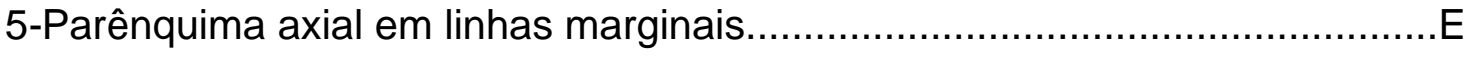

6-Parênquima axial invisível mesmo sob lente...............................................

7-Parênquima marginal, vasicêntrico e aliforme..............................................

8-Parênquima axial em faixas largas envolvendo ou ligando os poros...............H

A1-Parênquima aliforme losangular.

A2-Parênquima aliforme linear.

pauterro (Caesalpinia ferrea), tanheiro (Alchornea sidifolia), bico-de-pato (Machaerium aculeatum)

A1.1.1-Parênquima aliforme losangular intercalado por linhas de parênquima marginal.

A1.1.2-Somente parênquima aliforme losangular.

A1.1.1.1.a-Poros vazios e cerne de coloração bege castanho avermelhado .canafístula (Cassia ferruginea)

A1.1.1.1.b-Poros com a presença de tilos e cerne castanho avermelhado ..pautpereira (Platycyamus regnelli) 
A1.1.1.1.c-Raios estratificados

A1.1.1.1.c.1

A1.1.1.1.c.1.a-Poros vazios .jacarandá-paulista (Machaerium villosum)

A1.1.1.1.c.1.b-Poros obstruídos por substância amarelada (ipeína) ipêamarelo (Tabebuia chrysotricha)

A1.1.1.1.d-cerne com coloração pardo-claro capitão-do-campo (Terminalia brasiliensis)

A1.1.2.1.a-Cerne com coloração amarelo vivo ao castanho avermelhado, com veios enegrecidos e poros com resina avermelhada araribá (Centrolobium sp.)

A1.1.2.1.b-Cerne com coloração castanha. A1.1.2.1.b.1

A1.1.2.1.b.1.a-Raios estratificados. cumaru (Dipteryx sp.) A1.1.2.1.b.1.b-Raios não estratificados chá-de-bugre (Cordia sellowiana)

A2.a-Parênquima aliforme linear confluente formando faixas longas estreitas e irregulares pauferro (Caesalpinia ferrea), bico-de-pato (Machaerium aculeatum)

A2.a.1-Camadas de crescimento distintas. pau-ferro (Caesalpinia ferrea)

A2.a.2-Camadas de crescimento indistintas. bico-de-pato (Machaerium aculeatum)

A2.b-Parênquima aliforme linear. tanheiro (Alchornea sidifolia) 
B.1-Cerne de coloração branco-palha-

canxim (Pachystroma ilicifolium)

B.2-Cerne de coloração castanho-escuro

quaresmeira (Tibouchina granulosa)

C1-Poros pequenos a médios, solitários e múltiplos

C1.1

C2-Poros muito pequenos, múltiplos em pequenas cadeias radiais.......guaraiúva (Securinega guarayuva)

C1.1.a-Cerne de cor branco encardido ou levemente rosado .jequitibábranco (Cariniana estrellensis)

C1.1.b-Cerne de cor bege rosado escuro jequitibárosa (Cariniana legalis)

C1.1.c-Cerne de coloração bege-amarelado capixingui (Crotonsp.)

D1-Somente parênquima vasicêntrico escasso D1.1 D2-Parênquima vasicêntrico escasso intercalado por linhas de parênquima marginal. D.2.2

D1.1.a-Presença de anéis porosos e coloração bege-rosada fruta depomba (Erythroxylum sp.)

D1.1.b-Porosidade difusa, coloração parda e odor perceptível agradável. imbuia (Ocotea porosa)

D1.1.C-Poros visíveis a olho nu, médios a grandes. paineira (Chorisia speciosa) 
D2.2.a-Presença de anéis semi-porosos. paujacaré (Piptadenia gonoacantha)

D2.2.b-Poros visíveis a olho nu e cerne coloração branco-palha guapuruvu (Schizolobium parahyba)

D2.2.c-Poros visíveis a olho nu e cerne coloração castanhoavermelhada unha-de-vaca (Bauhinia forficata)

D2.2.d-Cerne coloração castanho-avermelhado-escuro angicopreto (Piptadenia macrocarpa)

E1.a-Cerne com coloração castanho-escuro E1.a.1

E1.a.1.a-Camadas de crescimento individualizadas por zonas fibrosas tangenciais mais escuras........................................ pitangueira (Eugenia uniflora) E1.a.1.b-Camadas de crescimento individualizadas pelo parênquima marginal. embiruçu (Bombax grandiflorum)

E1.b-Cerne sem essa coloração E1.b.1

E1.b.1.a-Cerne com coloração amarelo-dourado guarantã (Esenbeckia leiocarpa)

E1.b.1.b-Cerne com coloração castanho-claro .cambará (Gochnatia polymorpha)

E1.b.1.c-Cerne com coloração bege. perobaPoca (Aspidosperma cylindrocarpon)

E1.b.1.d-Cerne com coloração amarelada. guatambu (Aspidosperma ramiflorum)

F1-Cerne de coloração rosa perobarosa (Aspidosperma polyneuron) 
F2-Cerne e alburno distintos pela cor .aroeira-vermelha (Schinus terebinthifolius)

F3-Cerne e alburno indistintos pela cor F3.1

F3.1.a-Camadas de crescimento distintas individualizadas por zonas fibrosas tangenciais mais escuras .caraporoca (Rapanea umbellata), mamica-de-porca (Zanthoxylum rhoifolium), candiúba (Trema micrantha)

F3.1.a.1-Cerne com coloração castanho avermelhado caraporoca (Rapanea umbellata)

F3.1.a.2-Cerne com coloração bege acastanhado candiúba (Trema micrantha)

F3.1.a.3-Cerne com coloração bege esverdeado mamica-de-porca (Zanthoxylum rhoifolium)

F3.1.b-Camadas de crescimento indistintas guaritá (Astronium graveolens), guaicá (Ocotea puberula), mutambo (Guazuma ulmifolia)

F3.1.b.1-Cerne com coloração bege-amarelado guaritá (Astronium graveolens)

F3.1.b.2-Cerne com coloração pardo-acastanhado. guaicá (Ocotea puberula)

F3.1.b.3-Cerne com coloração bege escuro mutambo (Guazuma ulmifolia)

G1-Presença de canais secretores axiais localizadas nas faixas marginais copaíba (Copaifera langsdorfii) G2-Ausência de canais secretores axiais .jatobá (Hymenaea courbari)

$\mathrm{H}-$ canjarana (Cabralea canjerana) 


\subsection{Chave para identificação microscópica das espécies selecionadas através de suas madeiras (identificação por computador):}

Com base na descrição da estrutura microscópica da madeira foi elaborada uma chave de identificação das diferentes espécies florestais. Essa chave de classificação é apropriada para uso em computador na qual, para cada carcterística anatômica microscópica da madeira são relacionadas as respectivas espécies. $\mathrm{Na}$ fase seguinte, pela aplicação do programa, com o conjunto das características, são indicadas algumas espécies que deverão ser analisadas pelo pesquisador para a confirmação e diagnóstico final.

\section{VASOS}

Porosidade:

- em anéis porosos........................................fruta-de-pomba (Erythroxylum sp.), guatambu (Aspidosperma ramiflorum)

- em anéis semi-porosos...........................pau-jacaré (Piptadenia gonoacantha)

- difusa...............araribá (Centrolobium sp.), canxim (Pachystroma ilicifolium), jequitibá-branco (Cariniana estrellensis), jequitibá-rosa (Cariniana legalis), imbuia (Ocotea porosa), canafístula (Cassia ferruginea), pautpereira (Platycyamus regnelli), peroba-rosa (Apidosperma polyneuron), guarantã (Esenbeckia leiocarpa), cumaru (Dipterryx sp.), angico-preto (Piptadenia macrocarpa), pau-ferro (Caesalpinia ferrea), guaraiúva (Securinega guarayuva), jacarandá-paulista (Machaerium villosum), guapuruvu (Schizolobium parahyba), copaíba (Copaifera langsdorfii), quaresmeira (Tibouchina granulosa), cambará (Gochnatia polymorpha), paineira (Chorisia speciosa), tanheiro (Alchornea sidifolia), aroeira-vermelha (Schinus terebinthifolius), unha-de-vaca (Bauhinia forficata), caraporoca (Rapanea umbellata), pitangueira (Eugenia uniflora), capitão-do-campo (Terminalia brasiliensis), guaritá (Astronium graveolens), jatobá (Hymenaea courbaril), embiruçu (Bombax grandiflorum), peroba-poca (Aspidosperma 
cylindrocapon), chá-de-bugre (Cordia sellowiana), ipê-amarelo (Tabebuia chrysotricha), canjarana (Cabralea canjerana), bico-de-pato (Machaerium aculeatum), guaicá (Ocotea puberula), capixingui (Croton sp.), mamica-deporca (Zanthoxylum rhoifolium), mutambo (Guazuma ulmifolia), candiúba (Trema micrantha)

Arranjo:

- tangencial.........araribá (Centrolobium sp.), jequitibá-branco (Cariniana estrellensis), jequitibá-rosa (Cariniana legalis), fruta-de-pomba (Erythroxylum sp.), imbuia (Ocotea porosa), canafístula (Cassia ferruginea), pau-pereira (Platycyamus regnelli), peroba-rosa (Apidosperma polyneuron), guarantã (Esenbeckia leiocarpa), cumaru (Dipteryx sp.), angico-preto (Piptadenia macrocarpa), pau-ferro (Caesalpinia ferrea), guaraiúva (Securinega guarayuva), jacarandá-paulista (Machaerium villosum), guapuruvu (Schizolobium parahyba), copaíba (Copaifera langsdorfii), quaresmeira (Tibouchina granulosa), paineira (Chorisia speciosa), tanheiro (Alchornea sidifolia), aroeira-vermelha (Schinus terebinthifolius), unha-de-vaca (Bauhinia forficata), caraporoca (Rapanea umbellata), pitangueira (Eugenia uniflora), capitão-do-campo (Terminalia brasiliensis), guaritá (Astronium graveolens), jatobá (Hymenaea courbaril), embiruçu (Bombax grandiflorum), peroba-poca (Aspidosperma cylindrocapon), chá-de-bugre (Cordia sellowiana), ipêamarelo (Tabebuia chrysotricha), canjarana (Cabralea canjerana), bico-depato (Machaerium aculeatum), guaicá (Ocotea puberula), capixingui (Croton sp.)

- diagonal..............canxim (Pachystroma ilicifolium), cambará (Gochnatia polymorpha)

- em cacho......................................................mbará (Gochnatia polymorpha)

Agrupamento: 
- solitários na maioria........araribá (Centrolobium sp.), canafístula (Cassia ferruginea), pau-pereira (Platycyamus regnelli), peroba-rosa (Apidosperma polyneuron), cumaru (Dipterryx sp.), pau-ferro (Caesalpinia ferrea), jacarandá-paulista (Machaerium villosum), pau-jacaré (Piptadenia gonoacantha), pitangueira (Eugenia uniflora), jatobá (Hymenaea courbaril), peroba-poca (Aspidosperma cylindrocarpon), guatambu (Aspidosperma ramiflorum), bico-de-pato (Machaerium aculeatum), candiúba (Trema micrantha)

- múltiplos na maioria....guarantã (Esenbeckia leiocarpa), guaraiúva (Securinega guarayuva), cambará (Gochnatia polymorpha), aroeira-vermelha (Schinus terebinthifolius), caraporoca (Rapanea umbellata), embiruçu (Bombax grandiflorum), chá-de-bugre (Cordia sellowiana), capitão-do-campo (Terminalia brasiliensis)

- solitários e múltiplos...........canxim (Pachystroma ilicifolium), jequitibá-branco (Cariniana estrellensis), jequitibá-rosa (Cariniana legalis), fruta-de-pomba (Erythroxylum sp.), imbuia (Ocotea porosa), angico-preto (Piptadenia macrocarpa), guapuruvu (Schizolobium parahyba), copaíba (Copaifera langsdorfii), quaresmeira (Tibouchina granulosa), paineira (Chorisia speciosa), tanheiro (Alchornea sidifolia), unha-de-vaca (Bauhinia forficata), ipê-amarelo (Tabebuia chrysotricha), guaritá (Astronium graveolens), canjarana (Cabralea canjerana), guaicá (Ocotea puberula), capixingui (Croton sp.), mamica-de-porca (Zanthoxylum rhoifolium), mutambo (Guazuma ulmifolia)

Forma da secção:

- arredondada......................canxim (Pachystroma ilicifolium), jequitibá-branco (Cariniana estrellensis), jequitibá-rosa (Cariniana legalis), fruta-de-pomba (Erythroxylum sp.), imbuia (Ocotea porosa), canafístula (Cassia ferruginea), peroba-rosa (Aspidosperma polyneuron), guarantã (Esenbeckia leiocarpa), cumaru (Dipteryx sp.), angico-preto (Piptadenia macrocarpa), pau-ferro 
(Caesalpinia ferrea), guaraiúva (Securinega guarayuva), jacarandá-paulista (Machaerium villosum), pau-jacaré (Piptadenia gonoacantha), guapuruvu (Schizolobium parahyba), copaíba (Copaifera langsdorfii), quaresmeira (Tibouchina granulosa), cambará (Gochnatia polymorpha), paineira (Chorisia speciosa), tanheiro (Alchornea sidifolia), aroeira-vermelha (Schinus terebinthifolius), unha-de-vaca (Bauhinia forficata), caraporoca (Rapanea umbellata), pitangueira (Eugenia uniflora), capitão-do-campo (Terminalia brasiliensis), guaritá (Astronium graveolens), jatobá (Hymenaea courbari), embiruçu (Bombax grandiflorum), peroba-poca (Aspidosperma cylindrocarpon), chá-de-bugre (Cordia sellowiana), ipê-amarelo (Tabebuia chrysotricha), guatambu (Aspidosperma ramiflorum), bico-de-pato (Machaerium aculeatum), guaicá (Ocotea puberula), mamica-de-porca (Zanthoxylum rhoifolium), mutambo (Guazuma ulmifolia), candiúba (Trema micrantha)

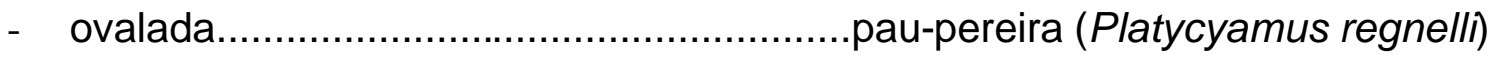

- arredondada a ovalada .........................................araribá (Centrolobium sp.), capixingui (Croton sp.), canjarana (Cabralea canjerana)

Placas de perfuração:

- simples..............araribá (Centrolobium sp.), canxim (Pachystroma ilicifolium), jequitibá-branco (Cariniana estrellensis), jequitibá-rosa (Cariniana legalis), fruta-de-pomba (Erythroxylum sp.), imbuia (Ocotea porosa), canafístula (Cassia ferruginea), pau-pereira (Platycyamus regnelli), peroba-rosa (Apidosperma polyneuron), guarantã (Esenbeckia leiocarpa), cumaru (Dipteryx sp.), angico-preto (Piptadenia macrocarpa), pau-ferro (Caesalpinia ferrea), guaraiúva (Securinega guarayuva), jacarandá-paulista (Machaerium villosum), pau-jacaré (Piptadenia gonoacantha), guapuruvu (Schizolobium parahyba), copaíba (Copaifera langsdorfii), quaresmeira (Tibouchina granulosa), cambará (Gochnatia polymorpha), paineira (Chorisia speciosa), tanheiro (Alchornea sidifolia), aroeira-vermelha (Schinus terebinthifolius), 
unha-de-vaca (Bauhinia forficata), caraporoca (Rapanea umbellata), pitangueira (Eugenia uniflora), capitão-do-campo (Terminalia brasiliensis), guaritá (Astronium graveolens), jatobá (Hymenaea courbari), embiruçu (Bombax grandiflorum), peroba-poca (Aspidosperma cylindrocapon), chá-debugre (Cordia sellowiana), ipê-amarelo (Tabebuia chrysotricha), guatambu (Aspidosperma ramiflorum), capixingui (Croton sp.), canjarana (Cabralea canjerana), bico-de-pato (Machaerium aculeatum), guaicá (Ocotea puberula), mamica-de-porca (Zanthoxylum rhoifolium), mutambo (Guazuma ulmifolia), candiúba (Trema micrantha)

Tilos:

- abundantes....................jequitibá-rosa (Cariniana legalis), canafístula (Cassia ferruginea), pau-ferro (Caesalpinia ferrea), guaraiúva (Securinega guarayuva), pau-jacaré (Piptadenia macrocarpa), quaresmeira (Tibouchina granulosa), unha-de-vaca (Bauhinia forficata), guaritá (Astronium graveolens)

- não abundantes............araribá (Centrolobium sp.), canxim (Pachystroma ilicifolium), jequitibá-branco (Cariniana legallis), fruta-de-pomba (Erythroxylum sp.), imbuia (Ocotea porosa), pau-pereira (Platycyamus regnelli), peroba-rosa (Aspidosperma polyneuron), angico-preto (Piptadenia macrocarpa), jacarandá-paulista (Machaerium villosum), guapuruvu (Schizolobium parahyba), copaíba (Copaifera langsdorfii), cambará (Gochnatia polymorpha), paineira (Chorisia speciosa), tanheiro (Alchornea sidifolia), aroeira-vermelha (Schinus terebnthifolius), caraporoca (Rapanea umbellata), pitangueira (Eugenia uniflora), jatobá (Hymenaea courbaril, embiruçu (Bombax grandiflorum), peroba-poca (Aspidosperma cylindrocarpon), chá-de-bugre (Cordia sellowiana), ipê-amarelo (Tabebuia chrysotricha), guatambu (Aspidosperma ramiflorum), capitão-do-campo (Terminalia brasiliensis), capixingui (Croton sp.), canjarana (Cabralea canjerana), bico-de-pato (Machaerium aculeatum), guaicá (Ocotea puberula), 
mamica-de-porca (Zanthoxylum rhoifolium), mutambo (Guazuma ulmifolia), candiúba (Trema micrantha)

Pontoações intervasculares:

- arranjo:

•escalariformes............cambará (Gochnatia polymorpha)

-opostas canxim (Pachystroma ilicifolium), pitangueira (Eugenia uniflora)

-alternas araribá

(Centrolobium

sp.), jequitibá-branco (Cariniana estrellensis), jequitibá-rosa (Cariniana legalis), fruta-de-pomba (Erythroxylum sp.), imbuia (Ocotea porosa), canafístula (Cassia ferruginea), pau-pereira (Platycyamus regnelli), peroba-rosa (Aspidosperma polyneuron), guarantã (Esenbeckia leiocarpa), cumaru (Dipteryx sp.), angico-preto (Piptadenia macrocarpa), pau-ferro (Caesalpinia ferrea), guaraiúva (Securinega guarayuva), jacarandá-paulista (Machaerium villosum), paujacaré (Piptadenia gonoacantha), guapuruvu (Schizolobium parahyba), copaíba (Copaifera langsdorfii), quaresmeira (Tibouchina granulosa), cambará (Gochnatia polymorpha), paineira (Chorisia speciosa), tanheiro (Alchornea sidifolia), aroeira-vermelha (Schinus terebinthifolius), unha-devaca (Bauhinia forficata), caraporoca (Rapanea umbellata), capitão-docampo (Terminalia brasiliensis), guaritá (Astronium graveolens), jatobá (Hymenaea courbaril), embiruçu (Bombax grandiflorum), peroba-poca (Aspidosperma cylindrocapon), chá-de-bugre (Cordia sellowiana), ipêamarelo (Tabebuia chrysotricha), guatambu (Aspidosperma ramiflorum), capixingui (Croton sp.), canjarana (Cabralea canjerana), bico-de-pato (Machaerium aculeatum), guaicá (Ocotea puberula), mamica-de-porca (Zanthoxylum rhoifolium), mutambo (Guazuma ulmifolia), candiúba (Trema micrantha)

- formas: 
-arredondadas araribá (Centrolobium sp.), canxim (Pachystroma ilicifolium), jequitibá-branco (Cariniana estrellensis), jequitibá-rosa (Cariniana legalis), fruta-de-pomba (Erythroxylum sp.), imbuia (Ocotea porosa), canafístula (Cassia ferruginea), pau-pereira (Platycyamus regnelli), perobarosa (Aspidosperma polyneuron), guarantã (Esenbeckia leiocarpa), angicopreto (Piptadenia macrocarpa), pau-ferro (Caesalpinia ferrea), guaraiúva (Securinega guarayuva), jacarandá-paulista (Machaerium villosum), paujacaré (Piptadenia gonoacantha), guapuruvu (Schizolobium parahyba), copaíba (Copaifera langsdorfii), quaresmeira (Tibouchina granulosa), cambará (Gochnatia polymorpha), paineira (Chorisia speciosa), tanheiro (Alchornea sidifolia), aroeira-vermelha (Schinus terebinthifolius), unha-devaca (Bauhinia forficata), caraporoca (Rapanea umbellata), pitangueira (Eugenia uniflora), capitão-do-campo (Terminalia brasiliensis), guaritá (Astronium graveolens), jatobá (Hymenaea courbari), embiruçu (Bombax grandiflorum), peroba-poca (Aspidosperma cylindrocapon), chá-de-bugre (Cordia sellowiana), ipê-amarelo (Tabebuia chrysotricha), guatambu (Aspidosperma ramiflorum), capixingui (Croton sp.), canjarana (Cabralea canjerana), bico-de-pato (Machaerium aculeatum), guaicá (Ocotea puberula), mamica-de-porca (Zanthoxylum rhoifolium), mutambo (Guazuma ulmifolia)

-poligonais (Dipteryx sp.), candiúba

(Trema micrantha)

ornamentações:

-presentes. .araribá (Centrolobium

sp.), pau-pereira (Platycyamus regnelli), cumaru (Dipteryx sp.), jacarandá-paulista (Machaerium villosum), jatobá (Hymenaea courbari), guaicá (Ocotea puberula)

-ausentes. canxim (Pachystroma ilicifolium), jequitibá-branco (Cariniana estrellensis), jequitibá-rosa (Cariniana legalis), fruta-de-pomba (Erythroxylum sp.), imbuia (Ocotea porosa), canafístula (Cassia ferruginea), 
peroba-rosa (Aspidosperma polyneuron), guarantã (Esenbeckia leiocarpa), angico-preto (Piptadenia macrocarpa), pau-ferro (Caesalpinia ferrea), guaraiúva (Securinega guarayuva), pau-jacaré (Piptadenia gonoacantha) guapuruvu (Schizolobium parahyba), copaíba (Copaifera langsdorfii), quaresmeira (Tibouchina granulosa), cambará (Gochnatia polymorpha), paineira (Chorisia speciosa), tanheiro (Alchornea sidifolia), aroeira-vermelha (Schinus terebinthifolius), unha-de-vaca (Bauhinia forficata), caraporoca (Rapanea umbellata), pitangueira (Eugenia uniflora), capitão-do-campo (Terminalia brasiliensis), guaritá (Astronium graveolens), embiruçu (Bombax grandiflorum), peroba-poca (Aspidosperma cylindrocapon), chá-de-bugre (Cordia sellowiana), ipê-amarelo (Tabebuia chrysotricha), guatambu (Aspidosperma ramiflorum), capixingui (Croton sp.), canjarana (Cabralea canjerana), bico-de-pato (Machaerium aculeatum), mamica-de-porca (Zanthoxylum rhoifolium), mutambo (Guazuma ulmifolia), candiúba (Trema micrantha)

Pontoações radiovasculares:

-semelhantes às intervasculares.......araribá (Centrolobium sp.), canxim (Pachystroma ilicifolium), jequitibá-branco (Cariniana estrellensis), jequitibárosa (Cariniana legalis), fruta-de-pomba (Erythroxylum sp.), imbuia (Ocotea porosa), canafístula (Cassia ferruginea), pau-pereira (Platycyamus regnelli), peroba-rosa (Aspidosperma polyneuron), guarantã (Esenbeckia leiocarpa), cumaru (Dipteryx sp.), angico-preto (Piptadenia macrocarpa), pau-ferro (Caesalpinia ferrea), guaraiúva (Securinega guarayuva), jacarandá-paulista (Machaerium villosum), pau-jacaré (Piptadenia gonoacantha), guapuruvu (Schizolobium parahyba), copaíba (Copaifera langsdorfii), quaresmeira (Tibouchina granulosa), cambará (Gochnatia polymorpha), paineira (Chorisia speciosa), tanheiro (Alchornea sidifolia), aroeira-vermelha (Schinus terebinthifolius), unha-de-vaca (Bauhinia forficata), caraporoca (Rapanea umbellata), pitangueira (Eugenia uniflora), capitão-do-campo (Terminalia 
brasiliensis), guaritá (Astronium graveolens), jatobá (Hymenaea courbari), embiruçu (Bombax grandiflorum), peroba-poca (Aspidosperma cylindrocapon), chá-de-bugre (Cordia sellowiana), ipê-amarelo (Tabebuia chrysotricha), guatambu (Aspidosperma ramiflorum), capixingui (Croton sp.), canjarana (Cabralea canjerana), bico-de-pato (Machaerium aculeatum), guaicá (Ocotea puberula), mamica-de-porca (Zanthoxylum rhoifolium), mutambo (Guazuma ulmifolia), candiúba (Trema micrantha)

\section{FIBRAS}

Comprimento:

- muito curtas (menor ou igual a $900 \mu \mathrm{m}$ )..............pautpereira (Platycyamus regnelli), jacarandá-paulista (Machaerium villosum), pau-jacaré (Piptadenia gonoacantha), quaresmeira (Tibouchina granulosa), aroeira-vermelha (Schinus terebinthifolius), caraporoca (Rapanea umbellata), pitangueira (Eugenia uniflora), ipê-amarelo (Tabebuia chrysotricha), bico-de-pato (Machaerium aculeatum)

- curtas (de 900 a $1600 \mu \mathrm{m}$ )..........................araribá (Centrolobium sp.), canxim (Pachystroma ilicifolium), jequitibá-branco (Cariniana estrellensis), jequitibárosa (Cariniana legalis), fruta-de-pomba (Erythroxylum sp.), imbuia (Ocotea porosa), canafístula (Cassia ferruginea), guarantã (Esenbeckia leiocarpa), cumaru (Dipteryx sp.), angico-preto (Piptadenia macrocarpa), pau-ferro (Caesalpinia ferrea), guapuruvu (Schizolobium parahyba), copaíba (Copaifera langsdorfii), cambará (Gochnatia polymorpha), paineira (Chorisia speciosa), tanheiro (Alchornea sidifolia), unha-de-vaca (Bauhinia forficata), jatobá (Hymenaea courbari), peroba-poca (Aspidosperma cylindrocarpon), chá-debugre (Cordia sellowiana), guatambu (Aspidosperma ramiflorum), capitão-docampo (Terminalia brasiliensis), guaritá (Astronium graveolens), capixingui (Croton sp.), guaicá (Ocotea puberula), mamica-de-porca (Zanthoxylum rhoifolium), mutambo (Guazuma ulmifolia), candiúba (Trema micrantha) 
- longas (maior que $1600 \mu \mathrm{m}$ ).................................peroba-rosa (Aspidosperma polyneuron), guaraiúva (Securinega guarayuva), embiruçu (Bombax grandiflorum), canjarana (Cabralea canjerana)

Espessura da parede:

- paredes delgadas............................... bico-de-pato (Machaerium aculeatum)

- paredes delgadas a espessas ...................araribá (Centrolobium sp.), jequitibárosa (Cariniana legalis), fruta-de-pomba (Erythroxylum sp.), imbuia (Ocotea porosa), canafístula (Cassia ferruginea), jacarandá-paulista (Machaerium villosum), pau-jacaré (Piptadenia gonoacantha), guapuruvu (Schizolobium parahyba), copaíba (Copaifera langsdorfii), quaresmeira (Tibouchina granulosa), cambará (Gochnatia polymorpha), paineira (Chorisia speciosa), tanheiro (Alchornea sidifolia), aroeira-vermelha (Schinus terebinthifolius), unha-de-vaca (Bauhinia forficata), caraporoca (Rapanea umbellata), capitãodo-campo (Terminalia brasiliensis), guaritá (Astronium graveolens), jatobá (Hymenaea courbari), embiruçu (Bombax grandiflorum), peroba-poca (Aspidosperma cylindrocapon), chá-de-bugre (Cordia sellowiana), guatambu (Aspidosperma ramiflorum), capixingui (Croton sp.), guaicá (Ocotea puberula), canjarana (Cabralea canjerana), mamica-de-porca (Zanthoxylum rhoifolium), mutambo (Guazuma ulmifolia), candiúba (Trema micrantha)

- paredes muito espessas..............................canxim (Pachystroma ilicifolium), jequitibá-branco (Cariniana estrellensis), pau-pereira (Platycyamus regnelli), peroba-rosa (Aspidosperma polyneuron), guarantã (Esenbeckia leiocarpa), cumaru (Dipteryx sp.), angico-preto (Piptadenia macrocarpa), pau-ferro (Caesalpinia ferrea), guaraiúva (Securinega guarayuva), pitangueira (Eugenia uniflora), ipê-amarelo (Tabebuia chrysotricha)

\section{PARÊNQUIMA AXIAL}

Ausente:

Apotraqueal: 
- difuso.

peroba-rosa

(Aspidosperma

polyneuron), guaraiuva (Securinega guarayuva), paineira (Chorisia speciosa), aroeiravermelha (Schinus terebinthifolius), caraporoca (Rapanea umbellata), peroba-poca (Aspidosperma cylindrocarpon), guatambu (Aspidosperma ramiflorum), guaicá (Ocotea puberula)

- difuso em agregados. tanheiro

(Alchornea sidifolia), pitangueira (Eugenia uniflora), embiruçu (Bombax grandiflorum), mutambo (Guazuma ulmifolia)

Paratraqueal

- escasso fruta-de-pomba (Erythoxylum sp.), guarantã (Esenbeckia leiocarpa), capitão-do-campo (Terminalia brasiliensis), mamicade-porca (Zanthoxylum rhoifolium), candiúba (Trema micrantha)

- vasicêntrico........................imbuia (Ocotea porosa), angico-preto (Piptadenia macrocarpa), pau-jacaré (Piptadenia gonoacantha), guapuruvu (Schizolobium parahyba), copaíba (Copaifera langsdorfii), cambará (Gochnatia polymorpha), paineira (Chorisia speciosa), unha-de-vaca (Bauhinia forficata), guaritá (Astronium graveolens)

- aliforme:

- linear tanheiro (Alchornea sidifolia), bico-de-pato (Machaerium aculeatum)

- losangular....................araribá (Centrolobium sp), canafístula (Cassia ferruginea), cumaru (Dipteryx sp.), pau-jacaré (Piptadenia gonoacantha), guapuruvu (Schizolobium parahyba), copaíba (Copaifera langsdorfii)

-confluente.........................pau-pereira (Platycyamus regnelli), pauferro (Caesalpinia ferrea), jacarandá-paulista (Machaerium vilosum), quaresmeira (Tibouchina granulosa), jatobá (Hymenaea courbaril), chá-debugre (Cordia sellowiana), ipê-amarelo (Tabebuia chrysotricha), capitão-docampo (Terminalia brasiliensis)

Faixas 
- faixas ou linhas.....................canxim (Pachystroma ilicifolium), pau-jacaré (Piptadenia gonoacantha), guapuruvu (Schizolobium parahyba), paineira (Chorisia speciosa), canjarana (Cabralea canjerana), capixingui (Croton sp.)

- reticulado...............................jequitibá-branco (Cariniana estrellensis), jequitibá-rosa (Cariniana legalis)

- marginal cambará (Gochnatia polymorpha), unha-de-vaca (Bauhinia forficata), jatobá (Hymenaea courbaril), embiruçu (Bombax cylindrocarpon), guatambu (Aspidosperma ramiflorum), capitão-do-campo (Terminalia brasiliensis)

RAIOS

Largura:

- unisseriados na maioria.............araribá (Centrolobium sp.), canxim (Pachystroma ilicifolium), canafístula (Cassia ferruginea), cumaru (Dipteryx sp.), tanheiro (Alchornea sidifolia), capitão-do-campo (Terminalia brasiliensis) - multisseriados.................................jequitibá-branco (Cariniana estrellensis), jequitibá-rosa (Cariniana legalis), fruta-de-pomba (Erythroxylum sp.), imbuia (Ocotea porosa), pau-pereira (Platycyamus regnelli), peroba-rosa (Aspidosperma polyneuron), guarantã (Esenbeckia leiocarpa), angico-preto (Piptadenia macrocarpa), pau-ferro (Caesalpinia ferrea), guaraiúva (Securinega guarayuva), jacarandá-paulista (Machaerium villosum), paujacaré (Piptadenia gonoacantha), guapuruvu (Schizolobium parahyba), copaíba (Copaifera langsdorfii), quaresmeira (Tibouchina granulosa), cambará (Gochnatia polymorpha), paineira (Chorisia speciosa), aroeiravermelha (Schinus terebinthifolius), unha-de-vaca (Bauhinia forficata), caraporoca (Rapanea umbellata), pitangueira (Eugenia uniflora), guaritá (Astronium graveolens), jatobá (Hymenaea courbaril), embiruçu (Bombax grandiflorum), peroba-poca (Aspidosperma cylindrocapon), chá-de-bugre (Cordia sellowiana), ipê-amarelo (Tabebuia chrysotricha), guatambu (Aspidosperma ramiflorum), capixingui (Croton sp.), canjarana (Cabralea 
canjerana), bico-de-pato (Machaerium aculeatum), guaicá (Ocotea puberula), mamica-de-porca (Zanthoxylum rhoifolium), mutambo (Guazuma ulmifolia), candiúba (Trema micrantha)

Composição celular:

- homocelulares:

•todas as células procumbentes...............................araribá (Centrolobium sp.), jequitibá-branco (Cariniana estrellensis), jequitibá-rosa (Cariniana legalis), canafístula (Cassia ferruginea), pau-pereira (Platycyamus regnelli), peroba-rosa (Aspidosperma polyneuron), cumaru (Dipteryx sp.), angico-preto (Piptadenia macrocarpa), pau-ferro (Caesalpinia ferrea), pau-jacaré (Piptadenia gonoacantha), guapuruvu (Schizolobium parahyba), cambará (Gochnatia polymorpha), paineira (Chorisia speciosa), pitangueira (Eugenia uniflora), ipê-amarelo (Tabebuia chrysotricha), jatobá (Hymenaea courbari), guatambu (Aspidosperma ramiflorum), peroba-poca (Aspidosperma cylindrocarpon), capitão-do-campo (Terminalia brasiliensis), guaicá (Ocotea puberula)

-todas as células quadradas tanheiro (Alchornea sidifolia), caraporoca (Rapanea umbellata), candiúba (Trema micrantha)

- heterocelulares....................................canxim (Pachystroma ilicifolium), frutade-pomba (Erythroxylum sp.), imbuia (Ocotea porosa), guarantã (Esenbeckia leiocarpa), guaraiúva (Securinega guarayuva), jacarandá-paulista (Machaerium villosum), copaíba (Copaifera langsdorfii), quaresmeira (Tibouchina granulosa), aroeira-vermelha (Schinus terebinthifolius), unha-devaca (Bauhinia forficata), guaritá (Astronium graveolens), embiruçu (Bombax grandiflorum), chá-de-bugre (Cordia sellowiana), capixingui (Croton sp.), canjarana (Cabralea canjerana), bico-de-pato (Machaerium aculeatum), mamica-de-porca (Zanthoxylum rhoifolium), mutambo (Guazuma ulmifolia) 
Estratificação:

- estratificados. .araribá (Centrolobium sp.), cumaru (Dipteryx sp.), pauferro (Caesalpinia ferrea), jacarandá-paulista (Machaerium villosum), ipê-amarelo (Tabebuia chrysotricha), bico-de-pato (Machaerium aculeatum).

- não estratificados canxim (Pachystroma ilicifolium), jequitibá-branco (Cariniana estrellensis), jequitibá-rosa (Cariniana legalis), fruta-de-pomba (Erythroxylum sp.), imbuia (Ocotea porosa), canafístula (Cassia ferruginea), pau-pereira (Platycyamus regnelli), peroba-rosa (Aspidosperma polyneuron), guarantã (Esenbeckia leiocarpa), angico-preto (Piptadenia macrocarpa), guaraiúva (Securinega guarayuva), pau-jacaré (Piptadenia gonoacantha), guapuruvu (Schizolobium parahyba), copaíba (Copaifera langsdorfii), quaresmeira (Tibouchina granulosa), cambará (Gochnatia polymorpha), paineira (Chorisia speciosa), tanheiro (Alchornea sidifolia), aroeira-vermelha (Schinus terebinthifolius), unha-de-vaca (Bauhinia forficata), caraporoca (Rapanea umbellata), pitangueira (Eugenia uniflora), capitão-do-campo (Terminalia brasiliensis), guaritá (Astronium graveolens), jatobá (Hymenaea courbari), embiruçu (Bombax grandiflorum), peroba-poca (Aspidosperma cylindrocapon), chá-de-bugre (Cordia sellowiana), guatambu (Aspidosperma ramiflorum), capixingui (Croton sp.), canjarana (Cabralea canjerana), guaicá (Ocotea puberula), mamica-de-porca (Zanthoxylum rhoifolium), mutambo (Guazuma ulmifolia), candiúba (Trema micrantha)

\section{PRESENÇA DE CRISTAIS}

Em células do parênquima axial...............araribá (Centrolobium sp.), canxim (Pachystroma ilicifolium), jequitibá-branco (Cariniana estrellensis), jequitibárosa (Cariniana legalis), canafístula (Cassia ferruginea), pau-pereira (Platycyamus regnelli), peroba-rosa (Aspidosperma polyneuron), cumaru (Dipteryx sp.), angico-preto (Piptadenia macrocarpa), pau-ferro (Caesalpinia ferrea), jacarandá-paulista (Machaerium villosum), pau-jacaré (Piptadenia 
gonoacantha), unha-de-vaca (Bauhinia forficata), guatambu (Aspidosperma ramiflorum), capixingui (Croton sp.), bico-de-pato (Machaerium aculeatum), mutambo (Guazuma ulmifolia)

Em células do parênquima radial.............................tanheiro (Alchornea sidifolia), aroeira-vermelha (Schinus terebinthifolius), caraporoca (Rapanea umbellata), capitão-do-campo (Terminalia brasiliensis)

Em células do parênquima axial e do parênquima radial.....guarantã (Esenbeckia leiocarpa), copaíba (Copaifera langsdorfii), pitangueira (Eugenia uniflora) embiruçu (Bombax grandiflorum), peroba-poca (Aspidosperma cylindrocarpon), guaritá (Astronium graveolens)

PRESENÇA DE SÍLICA

Em células do parênquima axial............jatobá (Hymenaea courbari)

Em células do parênquima radial..................................jequitibá-rosa (Cariniana legalis), embiruçu (Bombax grandiflorum), guaritá (Astronium graveolens)

Em células do parênquima axial e do parênquima radial......jequitibá-branco (Cariniana estrellensis) 


\section{DISCUSSÃO}

\subsection{Em relação àmetodologia de coleta das amostras do lenho:}

A metodologia de coleta de amostras do lenho do tronco das árvores, proposta no presente trabalho, apresenta inúmeras vantagens em relação ao processo de extração de amostras normalmente utilizado com serrote, formão e outros equipamentos. A utilização de sonda metálica, com $1,5 \mathrm{~cm}$ de diâmetro, possibilita a retirada de amostras do lenho com formato cilíndrico, apropriada para estudos anatômicos macro e microscópicos e causando um ferimento circular e de pequenas dimensões no tronco das árvores. O ferimento é perfeitamente preenchido com amostra de madeira tratada e de igual tamanho, seguida da aplicação da massa, para evitar o ataque de fungos e insetos, permitindo, desta forma, a retirada de várias amostras durante as estações de crescimento. Pelo fato de que nas amostras do lenho fica preservada a casca, existe um grande potencial de utilização da sonda metálica para estudos de sazonalidade da atividade cambial e de anatomia da casca. O equipameno possui, porém algumas restrições de uso, principalmente no que se refere ao seu peso para o seu transporte no interior de mata e a longas distâncias.

\subsection{Em relação à estrutura anatômica do lenho em comparação com}

\section{a literatura:}

No presente item é realizada a comparação da estrutura anatômica da madeira das diferentes espécies florestais examinadas e sua descrição na 
literatura especializada. As diferenças observadas foram de natureza quantitativa - dimensões dos elementos anatômicos e, também qualitativa tipo, ausência e/ou presença da característica anatômica do lenho.

Araribá

Em relação à estrutura anatômica macroscópica do lenho da espécie não foram evidenciadas diferenças significativas entre os resultados e os da literatura exceto para as camadas de crescimento que Mainieri \& Pereira (1965) descreveram como demarcadas por zonas de tecido escuro, com transição de tamanho de poros e por escasso parênquima terminal. Para as características anatômicas microscópicas Mainieri \& Chimelo (1989) descrevem o diâmetro tangencial dos poros de 100 - $240 \mu \mathrm{m}$, em relação ao valor de $92,4 \mu \mathrm{m}$ para o lenho das árvores.

Canxim

As características anatômicas macroscópicas do lenho das espécies foram semelhantes às descritas na literatura (Mainieri \& Pereira, 1965; Mainieri \& Camargo, 1967). Para a estrutura anatômica microscópica as descrições de Mainieri \& Camargo (1967) e Mainieri \& Chimelo (1989) indicam espessura média da parede das fibras e demarcação das camadas de crescimento pelo achatamento do seu lume, não observadas nas amostras do lenho analisadas.

\section{Jequitibá-branco}

Não houve diferenças anatômicas macroscópicas do lenho em relação aos resultados da literatura (Tomazello Filho et a., 1984). As características anatômicas microscópicas apresentam diferenças para o comprimento e apêndices dos elementos vasculares, e espessura da parede das fibras. Para Barbosa et al. (1978) e Mainieri \& Chimelo (1989) os elementos vasculares têm 429 - $650 \mu \mathrm{m}$ de comprimento com $400 \mu \mathrm{m}$ nas amostras; com apêndice em apenas uma das extremidades do vaso e nas amostras do lenho examinadas 1 , 
2 ou mesmo a ausência de apêndices; fibras de paredes delgadas a médias e nas amostras muito espessas.

Jequitibá-rosa

Houve concordância nas características anatômicas macroscópicas do lenho dessa espécie.(Mainieri \& Camargo, 1967). No entanto, Mainieri \& Chimelo (1989) descrevem diâmetro tangencial dos vasos de $133 \mu \mathrm{m}$ e raios de 0,31 $\mathrm{mm}$ de altura,em relação aos valores de $108 \mu \mathrm{m}$, e $0,51 \mathrm{~mm}$, respectivamente.

Fruta-de-pomba

Mainieri \& Pereira (1965) indicam poros solitários e múltiplos e camadas de crescimento demarcadas por zonas fibrosas mais escuras, em comparação aos poros solitários (maioria) e as camadas de crescimento demarcadas por poros em anéis porosos.

Imbuia

As características anatômicas macroscópicas dessa espécie indicam que há diferença no no parênquima indistinto Mainieri et al. (1983) comparado ao parênquima distinto sob lente de 10x. Em relação a estrutura anatômica microscópica Mainieri \& Chimelo (1989) indicam placas de perfuração ocasionalmente múltiplas em relação a simples; diâmetro tangencial dos vasos com $89 \mu \mathrm{m}$, ao invés de $95 \mu \mathrm{m}$; elementos vasculares de $0,6 \mu \mathrm{mm}$ de comprimento em rela'ção aos de $0,5 \mathrm{~mm}$.

\section{Canafístula}

Os resultados das características anatômicas macroscópicas não revelam diferenças dos da literatura (Mainieri et al., 1983). 
Pontoações intervasculares guarnecidas e de diâmetro tangencial de 9 $12 \mu \mathrm{m}$ (Mainieri \& Chimelo, 1989) ao invés de pontoações não guarnecidas e diâmetro de $6 \mu \mathrm{m}$; as camadas de crescimento não foram demarcadas pelo achatamento do lume das fibras observadas nas análises.

\section{Pau-pereira}

A literatura consultada (Mainieri \& Pereira, 1965), descreve a demarcação das camadas de crescimento pelo parênquima marginal e por zonas fibrosas tangenciais mais escuras e tilos nos vasos, enquanto que os resultados indicam somente demarcação pelo parênquima marginal e vasos sem tilos. As características anatômicas microscópicas (Mainieri \& Chimelo, 1989), mostraram vasos de 160 - $250 \mu \mathrm{m}$ de diâmetro tangencial, pontoações intervasculares com 7 - $10 \mu \mathrm{m}$ de diâmetro tangencial e raios homocelulares;nos resultados o valor é de $142 \mu \mathrm{m}$ para diâmetro tangencial, $13 \mu \mathrm{m}$ para pontoações intervasculares e raios heterocelulares.

\section{Peroba-rosa}

$\mathrm{Na}$ estrutura anatômica macroscópica do lenho (Chimelo et al., 1976) os poros são solitários e múltiplos, e parcialmente obstruídos por óleo-resina e poros solitários e desobstruídos nas amostras analisadas.

Pela estrutura anatômica microscópica (Mainieri \& Chimelo, 1989) tem-se $3 \mu \mathrm{m}$ de diâmetro das pontoações intervasculares e ausência de cristais, para 7 $\mu \mathrm{m}$ de diâmetro e presença de cristais no parênquima axial.

\section{Guarantã}

A estrutura anatômica macroscópica do lenho (Mainieri \& Pereira, 1965) é coincidente com a encontrada. As características anatômicas microscópicas (Mainieri \& Chimelo, 1989) indicam $3 \mu \mathrm{m}$ de diâmetro tangencial das pontoações intervasculares e camadas de crescimento separadas por linhas do parênquima 
marginal, enquanto que obteve-se $5 \mu \mathrm{m}$ de diâmetro tangencial e camadas de crescimento delimitadas pelo aumento do lume das fibras.

\section{Cumaru}

A presença de resina amarela e de vasos obstruídos por tilos(Chimelo et al.,1976; IPT, 1981 e Tomazello Filho et al., 1984) ao invés de vasos desobstruídos e sem tilos.

O diâmetro tangencial dos vasos e das pontoações intervasculares é de $110 \mu \mathrm{m}$ e $6 \mu \mathrm{m}$, respectivamente em comparação a $97 \mu \mathrm{m} 10 \mu \mathrm{m}$.

\section{Angico-preto}

A estrutura anatômica macroscópica da espécie indica óleo-resina nos vasos(Mainieri \& Pereira, 1965) e ausnte no lenho analisado. Na estrutura anatômica microscópica (Mainieri \& Chimelo, 1989) os elementos vasculares têm 300 - $500 \mu \mathrm{m}$ de comprimento, pontoações intervasculares com 9 - $10 \mu \mathrm{m}$ de diâmetro tangencial, fibras com paredes delgadas a espessas e raios com 112 - $235 \mu \mathrm{m}$ de altura, em relação a $250 \mu \mathrm{m}$ de comprimento, 8,5 $\mu \mathrm{m}$ de diâmetro tangencial, fibras com paredes muito espessas e raios com $274 \mu \mathrm{m}$ de altura nas amostras de lenho analisadas.

\section{Pau-ferro}

Os resultados obtidos são semelhantes aos descritos por Mainieri (1983).

A diferença observada na estrutura anatômica microscópica de acordo com Paula \& Alves (1980) consiste nos raios predominantemente multisseriados em relação aos bi e trisseriados.

\section{Guaraiúva}

Os resultados não diferem em relação a estrutura anatômica macro (Mainieri \& Pereira, 1965) e microscópica (Alves, 1989) do lenho da espécie. 
Jacarandá-paulista

As características anatômicas macroscópicas são coincidentes com Mainieri et al. (1983), embora Barbosa et al. (1978) não descrevam camadas de crescimento presentes nas amostras e demarcadas por zonas fibrosas tangenciais mais escuras.

As diferenças da estrutura anatômica microscópica (Mainieri \& Chimelo, 1989) referem-se aos vasos de $146 \mu \mathrm{m}$ de diâmetro tangencial, pontoações intervasculares de $9 \mu \mathrm{m}$, fibras com $1,1 \mathrm{~mm}$ de comprimento, raios com 0,16 $\mathrm{mm}$ de altura e homocelulares.No lenho dos vasos têm-se diâmetro tangencial de $88 \mu \mathrm{m}$, pontoações intervasculares de $8 \mu \mathrm{m}$, fibras de $0,9 \mathrm{~mm}$, raios de 0,18 $\mathrm{mm}$ de altura e heterocelulares

\section{Pau-jacaré}

A estrutura anatômica macroscópica do lenho não se diferencia (Mainieri \& Chimelo, 1989), enquanto a microscópica apresenta caracteres diferentes como vasos com diâmetro tangencial de $163 \mu \mathrm{m}$, comprimento de $350 \mu \mathrm{m}$, pontoações intervasculares guarnecidas, fibras de $0,96 \mathrm{~mm}$ de comprimento, raios com $0,38 \mathrm{~mm}$ de altura. Nas amostras os vasos têm diâmetro tangencial de $133 \mu \mathrm{m}$, comprimento de $250 \mu \mathrm{m}$, pontoações intervasculares não guarnecidas, fibras de $0.89 \mathrm{~mm}$ de comprimento, raios com $0,22 \mathrm{~mm}$ de altura.

\section{Guapuruvu}

$\mathrm{Na}$ estrutura anatômica macroscópica não é encontrado parênquima marginal em linhas finas (Morales et al., 1979), como nos resultados. As pontoações intervasculares são guarnecidas e os raios com 3 - 4 células de largura (Mainieri \& Chimelo, 1989), embora observadas pontoações intervasculares não guarnecidas, raios uni e bisseriados e camadas de crescimento demarcadas pelo achatamento do lume das fibras. 


\section{Copaíba}

A estrutura anatômica macroscópica do lenho é similar (Barbosa, 1982) e a descrição das características anatômicas microscópicas (Mainieri \& Chimelo, 1989) mostram fibras com paredes delgadas e ausência de camadas de crescimento. As paredes das fibras são delgadas a espessas e com camadas de crescimento demarcadas pela variação do lume das fibras nas amostras examinadas.

\section{Cambará}

A estrutura anatômica do lenho dessa espécie não revelou (Alves, 1989) a presença do parênquima em linhas marginais, além do parênquima vasicêntrico que ocorre nas amostras analisadas.

\section{Paineira}

A presença de parênquima axial em faixas no lenho desta espécie não é indicada na literatura consultada (Alves, 1989).

\section{Tanheiro}

A literatura descreve a de poros médios a grandes (Mainieri \& Camargo, 1967), em relação aos pequenos observados na madeira.

Da mesma forma, os raios bi e trisseriados e heterocelulares descritos diferenciam-se dos unisseriados e homocelulares observados na madeira.

Unha-de-vaca

Machado et al. (1966), descreve a estrutura anatômica macroscópica dessa espécie como é descrita nos resultados obtidos.

Os elementos vasculares têm comprimento de $0,19-0,36 \mathrm{~mm}$ e raios homocelulares em relação a vasos com $0,54 \mathrm{~mm}$ e raios heterocelulares. 
Pitangueira

A estrutura anatômica macroscópica difere apenas em relação a visibilidade do parênquima axial, visível somente sob lente na literatura (Mainieri \& Chimelo, 1989) e visível a olho nu na amostra.

Em relação às características anatômicas microscópicas os vasos têm diâmetro tangencial de $80 \mu \mathrm{m}$ e $43 \mu \mathrm{m}$, o elemento vascular com $584 \mu \mathrm{m}$ e 200 $\mu \mathrm{m}$, o diâmetro das pontoações intervasculares com $6 \mu \mathrm{m}$ e $3 \mu \mathrm{m}$, fibras com $1,23 \mathrm{~mm}$ e $0,77 \mathrm{~mm}$ e raios com 0,58 e $0,77 \mathrm{~mm}$, hetero e homocelulares na literatura e nas amostras, respectivamente.

\section{Capitão-do-campo}

Não houve diferença na estrutura anatômica dessa espécie em relação à literatura (Pinho \& Camargo, 1979 e Alves, 1989).

\section{Jatobá}

A estrutura anatômica macroscópica do lenho dessa espécie não difere com a literatura consultada (Tomazello Filho et al., 1984 e Chimelo et al., 1976); a microscópica indica pontoações intervasculares com diâmetro tangencial de 3 - 5 e $9 \mu \mathrm{m}$, raios com altura de 0,14 - 0,55 e 1,55 mm, na literatura (IPT, 1981) e no observado.

\section{Guatambu}

A literatura (Mainieri \& Pereira, 1965) não mostra diferenças nos resultados da estrutura anatômica macroscópica do lenho.

\section{Guaritá}

A estrutura anatômica macroscópica do lenho da espécie é semelhante na literatura (Mainieri \& Pereira, 1965). A estrutura anatômica microscópica mostrou diferenças (Morales et al., 1979) no diâmetro tangencial e no 
comprimento dos elementos vasculares e cristais nas células dos raios, enquanto os resultados indicam nas células do parênquima axial e sílica nos raios (Mainieri \& Chimelo, 1989).

Chá-de-bugre

A estrutura anatômica do lenho dessa espécie não mostrou diferenças (Barbosa et al., 1978).

Canjarana

Não houve diferenças diferenças anatômicas do lenho em relação aos resultados obtidos e os da literatura (Calvino \& Mainieri, 1989).

Guaicá

Enquanto Calvino \& Mainieri (1989) descrevem raios heterocelulares e presença de cristais no lenho a descrição não menciona cristais, e os raios são homocelulares.

\section{Mamica-de-porca}

A estrutura anatômica do lenho dessa espécie não difere da literatura (Alves, 1989).

\section{Mutambo}

Enquanto Alves (1989) descreve o parênquima axial concêntrico do lenho, os resultados mostrou parênquima axial difuso em agregados.

\section{Candiúba}

A espécie possui pontoações intervasculares com diâmetro médio de 6,8 $\mu \mathrm{m}$, elementos vasculares com 0,45 $\mathrm{mm}$ de comprimento e raios heterocelulares (Pinheiro et al., 1994) em relação a pontoações intervasculares com 9,3 $\mu \mathrm{m}$, elementos vasculares com 0,27 $\mathrm{mm}$ e raios homocelulares. 


\section{CONCLUSÕES}

Os resultados do presente trabalho permitem concluir que:

1. Com respeito ao equipamento testado, a sonda metálica e o extrator motorizado de amostras do lenho do tronco das árvores mostraram-se eficientes, em comparação com os métodos tradicionais.

2. As principais vantagens dizem respeito a (i) redução significativa do nível de ferimento provocado no tronco e, em conseqüência, maior efetividade do processo de cicatrização, (ii) extração de amostras do lenho de diferentes dureza e de densidade, (iii) possibilidade de obter amostras completas, incluindo os tecidos das regiões do lenho, camada cambial e da casca, (iv) dimensão apropriada das amostras do lenho para exames macro e microscópicos, (v) possibilidade de coletas sucessivas de amostras da árvore visando analisar a sazonalidade da atividade cambial e formação do xilema e do floema, (vi) possibilidade de aplicação das amostras do lenho para estudos de dendrocronologia e de análise da madeira por densitometria de raios $X$.

3. As principais desvantagens dizem respeito ao (i) peso do equipamento e acessórios e (ii) dificuldades do seu transporte em extensas áreas de florestas naturais e de plantações florestais.

4. As espécies florestais foram identificadas com base nas características anatômicas macro e microscópicas do seu lenho, em comparação com os métodos clássicos.

5. As principais vantagens dizem respeito a (i) possibilidade de obtenção das amostras do lenho durante todo o período do ano e de permanência no 
campo, (ii) facilidade no acondicionamento e transporte das amostras do lenho para o seu posterior preparo e exame em condições de laboratório, (iii) exigência de menor espaço para 0 armazenamento e manutenção das amostras do lenho em laboratório, (iv) durabilidade e manuseio das lâminas histológicas em laboratório, (v) disponibilidade de chaves de classificação e de programas de computador para a identificação das espécies com base na estrutura anatômica de seus lenhos.

6. As principais desvantagens dizem respeito a (i) necessidade de se montar uma xiloteca com amostras padrão, (ii) inexistência de chaves de classificação com todas as espécies florestais do país, (iii) exigência de equipamentos de laboratório de pessoal técnico capacitado.

7. As variações da estrutura anatômica macro e microscópica do lenho das árvores das espécies florestais mostraram diferenças (i) entre e dentro das árvores das espécies e com relação às descrições da literatura. As diferenças foram de (ii) ordem quantitativa, relacionadas com as dimensões das células e/ou tecidos e (ii) qualitativa, relacionadas com o tipo de célula ou tecido ausente e/ou presente no lenho.

8. A identificação de espécies florestais através de suas madeiras constituise em ferramenta de elevada importância nos programas de conservação da biodividade, contribuindo para as pesquisas taxonômicas e filogenéticas 


\section{REFERÊNCIAS BIBLIOGRÁFICAS}

ASSESSORIA DE COMUNICAÇÃO E MARKETING. Mata atântica. Rio de Janeiro: A C \& M, 1984. 75p.

AGUILARA, A.F.J.A.; RAMOS, R.R.; GUTIERREZ, S.P.; CONTRERAS, A.A.; WEBER, C.C.C.; SAENZ, J.L.F. Study of the anti-hyperglycemic effect of plants used as antidiabetics. Journal of Ethnopharmacology, n.61, p.101$110,1998$.

ALMEIDA, S.P. de.; PROENÇA, C.E.B.; SANO, S.M.; RIBEIRO, J.F. Cerrado: espécies vegetais úteis. Planaltina: EMBRAPA, 1998. 464p.

ANDRADE, J.O.M.; ZVINAKEVICIUS, C.; FOELKEL, C.E.B.; SILVA, A.R. Madeiras tropicais para produção de celulose para papel: Trema micrantha. Cenibra Pesquisa, n.70, p.1-9, 1978.

AMAT, A.G.; DE BATTISTA, G.A.; ULIANA, R.F. Diuretic activity of Eugenia uniflora L. (Myrtaceae) aqueous extract. Acta Horticulturae, n.501, p.155158, 1999.

ANGYALOSSY - ALFONSO, V. Caracterização anatômica do lenho e da casca das principais espécies de Eucalyptus L'herit cultivadas no Brasil. São Paulo, 1987. 239p. Tese (Doutorado) - Instituto de Biociências, Universidade de São Paulo. 
BARBERA, R.; TROVATO, A.; RAPISARDA, A.; RAGUSA, S. Analgesic and antiinflamatory activity in acute and chronic conditions of Trema guineense (Schum. Et Thonn.) Ficalho and Trema micrantha Blume extracts in rodents. Phytotherapy Research, v.6, p.146-148, 1992.

BARBOSA, O.; BAITELLO, J.B.; MAINIERI, C.; MONTAGNA, R.G.; NEGREIROS, O.C. de. Identificação e fenologia de espécies arbóreas da Serra da Cantareira (São Paulo). Silvicultura em São Paulo, v.11, n.12, p.1168, 1978.

BARBOSA, O. Características estruturais do lenho de Copaifera langsdorfii Desf. e Copaifera lucens Dwyer. Silvicultura em São Paulo, v.15, n.16, p.23-36, 1982.

BASTOS, A. de M.; MILANEZ, F. R. Glossário dos termos usados em anatomia de madeiras. Separata do Boletim do Ministério da Agricultura, v.25, 1936, 19p.

BERTONI, J. E. de A. Composição florística e estrutura fitossociológica de uma floresta do interior do Estado de São Paulo: Reserva Estadual de Porto Ferreira. Campinas, 1984. 196p. Dissertação (Mestrado) - Faculdade de Biociências, Universidade Estadual de Campinas.

BORN, G. C. C. Comunidades tradicionais na estação ecológica da Juréia Itatins: biodiversidade e medicina popular. Revista do Instituto Florestal, v. 4 , n. 2 , p. $804-807,1992$.

BURGER, L.M.; RICHTER, H.G. Anatomia da madeira. São Paulo: Nobel, 1991. 154p. 
BURLE, M. Árvores - Trees Minas Gerais. Rio de Janeiro: AC\&M, 1988. 91p.

CARUSO, R. Cerrado brasileiro: desenvolvimento, preservação e sustentabilidade. Campinas: Fundação Cargill, 1997. 112p.

CARVALHO, J.C.T.; TEIXEIRA, J.R.M.; SOUZA, P.J.C.; BASTOS, J.K.; SANTOS FILHO, D.dos; SARTI, S.J. Preliminary studies of analgesic and antiinflamatory properties of Caesalpinia ferrea crude extract. Journal of Ethnopharmacology, v.53, p.175-178, 1996.

CHIMELO, J.P. Quantitative characterization of the microstructure of selected brazilian hardwood species using stereological methods. Virginia, 1978, 129p. Thesis (Master) - Virginia Polytechnic Institute and State University.

CHIMELO, J. P.; ANGYALOSSY - ALFONSO, V. Agrupamento de anatomia e identificação de madeiras. São Paulo: IPT, 1983. 37p.

CHIMELO, J.P.; MAINIERI, C.; NAHUZ, M.A.R.; PESSOA, A.L. madeiras do município de Aripuanã, Estado do Mato Grosso: I - Caracterização anatômica e aplicações. Acta Amazonica, v.6, n.5, p.95-106, 1976.

CHIMELO, J.P.; ZENID, G.J; MIRANDA, M.J.A.C.; CECCANTINI, G.C.T. IMAC - identificação de madeiras brasileiras com auxílio do computador. São Paulo: IPT, 1993. 56p.

CORADIN, V. T. R.; MUNIZ, G. I. B. Normas de procedimentos em estudos de anatomia da madeira: 1. Angiospermae, 2. Gimnospermae. Brasília: IBAMA, 1992. $17 \mathrm{p}$. 
CULLEN, J. R. L. Hunting and biodiversity in Atlantic forest fragments, São Paulo, Brasil. Gainsville, 1997. 144p. Thesis (Master) - University of Florida.

CUSTODIO FILHO, A.; FRANCO, G. A. D. C.; NEGREIROS, O. C. de; MARIANO, G.; GIANNOTTI, E.; DIAS, A. C. Composição florística da vegetação arbórea da mata mesófila semidecídua. Estação Ecológica de Ibicatu, Piracicaba, SP. Revista do Instituto Florestal, v.6, n. único, p.99 $111,1994$.

FERREIRINHA. M. P. Glossário internacional dos termos usados em anatomia de madeiras. Lisboa: Ministério do Ultramar - Junta de Investigações do Ultramar, 1958. 89p. (Estudos, ensaios e documentos 46).

FINGER, Z.; RAMALHO, R. da S.; BRANDI, R. M.; CÂNDIDO, J. F. Estudos dendrológicos da regeneração natural na microrregião de Viçosa, MG. I. Identificação e descrição de algumas espécies. Revista Árvore, v.3, n.1, p.94-119, 1979.

FRANKLIN, G. L. Permanent preparations of macerated wood fibers. Tropical woods, v.49, p.21-22, 1937.

FUNDAÇÃO DE PESQUISA FLORESTAL DO PARANÁ. Defeitos da madeira. Curitiba, 1980. 62p. (Série Técnica, 2).

FURTADO, J.I.; MORGAN, W.B.; PFAFFLIN, J.R.; RUDDLE, K. Tropical resources: ecology and development. Philadelphia: Hardwood Academic, 1992. 306p. 
GOODLAND. R.; FERRI, M. G. Ecologia do cerrado. São Paulo: EDUSP, 1979. 193p.

GRAZZIOTIN, J.D.; SCHAPOVAL, E.E.S.; CHAVES, C.G.; GLEYE, J.; HENRIQUES, A.T. Phytochemical and analgesic investigation of Tabebuia chrysotricha. Journal of Ethnopharmacology, v.36, p.249-251, 1992.

GURGEL FILHO, O. A. Essências indígenas. Silvicultura em São Paulo, v.9, p. $47-52,1975$.

INTERNATIONAL ASSOCIATION OF WOOD ANATOMISTS. List of Microscopic Features for Hardwood Identification. IAWA Bulletin, v.10, n.3, p.219-332, 1989.

INSTITUTO DE PESQUISAS TECNOLÓGICAS DO ESTADO DE SÃO PAULO. Madeiras da Reserva Florestal de Curuá-Una, Estado do Pará: caracterização anatômica, propriedades gerais e aplicações. São Paulo: IPT, 1981. 117p.

INSTITUTO DE PESQUISAS TECNOLÓGICAS DO ESTADO DE SÃO PAULODIVISÃO DE MADEIRAS. Madeira: o que é e como pode ser processada e utilizada. São Paulo: IPT, 1985. 189p. (Boletim, 36).

JANE, F. W. Aspects of the study of wood anatomy. Science Progress, v.3, p.439 - 454, Jan. 1934.

JOLY, A.B. Conheça a vegetação brasileira. São Paulo: EDUSP;Poligono, 1970. 165p. 
KAENNEL, M.; SCHWEINGRUBER, F.H. Multilingual glossary of dendrochonology: terms and definitions in english, german, french, spanish, italian, portuguese and russian. Birmensdorf: Swiss Federal Institute for Forest, Snow and Landscape Research, 1995. 467p.

KRONKA, F.J.N. Áreas de domínio do cerrado no Estado de São Paulo. São Paulo: Secretaria do Meio Ambiente, 1998. 84p.

LEMOS, A.V.; TOMAZELLO F, M; SOBRAL, L.M.; LISI, C.S. Uso de extrator motorizado para a retirada de amostras de madeira do tronco de árvores de Pinus spp. In: SIMPÓSIO INTERNACIONAL DE INICIAÇÃO CIENTÍFICA DA USP, 8., Piracicaba, 2000. resumos São Paulo: EDUSP, 2000. p.191.

LORENZI, H. Árvores brasileiras: manual de identificação e cultivo de plantas arbóreas nativas do Brasil. Nova Odessa: Editora Plantarum, 2 v., 1992 1998.

LUJÁN, M.C.; BARBOZA, G.E. Contribution to the study of some argentinian medicinal plants and commercial quality control. Acta Horticulturae, n.503, p.141-154, 1999.

MACHADO, R.D.; MATTOS FILHO, A.de; PEREIRA, J.M.G. Estrutura microscópica e sub-microscópica da madeira de Bauhinia forficata Link (Leg. Caes.). Rodriguésia, v.25, n.37, p.313-324.

MAINIERI, C. Identificação das principais madeiras de comércio no Brasil. São Paulo: IPT, 1958. 63p. (Boletim, 46).

MAINIERI, C. Manual de identificação das principais madeiras comerciais brasileiras. São Paulo: IPT, 1983. 241p. 
MAINIERI, C. Madeiras denominadas caixeta. São Paulo: IPT, 1958. 39p.

MAINIERI, C.; CAMARGO, M.J.P.de. Estudo anatômico de algumas madeiras brasileiras de parênquima apotraqueal zonado. São Paulo: IPT, 1967. 106p.

MAINIERI, C.; CHIMELO, J. P. Noções de anatomia de madeira como base para identificação. Boletim técnico da Associação Brasileira de Preservadores de Madeira, v.2, n.1, p.1 - 36, nov. 1974.

MAINIERI, C.; CHIMELO, J.P. Fichas de características das madeiras brasileiras. São Paulo: IPT, 1989. 432p.

MAINIERI, C.; PEREIRA, J.A. Madeiras do Brasil, sua caracterização macroscópica, usos comuns e índices qualitativos, físicos e mecânicos. Separata de Anuário Brasileiro de Economia Florestal, n.17, p.255, 1965.

MARIANO, G.; CRESTANA, C. de S. M.; BATISTA, E. A.; GIANNOTTI, E.; COUTO, H. T. Z. do. Regeneração natural em área àmargem de represa, no município de Piracicaba, SP. Revista do Instituto Florestal, v.10, n.1, p.8193, 1998.

MENDONÇA, W.F.; QUEIROZ, D.L.M. Produção de mata nativa no Estado do Espirito Santo. Floresta e Ambiente, v.4, p.117-123, 1997.

MILANEZ, F.R.; BASTOS, A. M. Multilingual glossary of terms used in wood anatomy. Rio de Janeiro: Commitee on Nomenclature; International Association of Wood Anatomists, 1964. 120p. 
MITTERMEIER, R. A.; MYERS, N.; MITTERMEIER, G. Hotspots. Earth's biologically richest and most endangered terrestrial ecoregions. México: Cemex - Conservation International, 2000. 431p.

MONTEIRO, M.R.; VIEIRA, P.C.; FERNANDES, J.B.; SILVA, M.F.G.F.da; ALBUQUERQUE, S.de; ZANI, C.L. Trypanocidal terpenoids from Cabralea canjerana (Meliaceae). In: ANNUAL MEETING OF THE AMERICAN SOCIETY OF PHARMACOGNOSY, 38., lowa City, 1997. lowa City: University of lowa, 1997. p.158.

MORALES, J.B.; DOMÍNGUEZ, S.R.; ECHENIQUE-MANRIQUE, R. Anatomía de maderas de México № 2: veinte especies de la selva lacandona. Biotica, v.4, n.4, p. 163-193, 1979.

MOREIRA, A.S.; SPITZER, V.; SCHAPOVAL, E.E.S.; SCHENKEL, E.P. Antiinflamatory activity of extracts and fractions from the leaves of Gochnatia polymorpha. Phytotherapy Research, v.14, 638-640, 2000.

MOURA, N.F.; GIACOMELLI, S.R.; MACHADO, E.C.; MOREL, A.F.; SILVEIRA, C.F.S.; BITTENCOURT, C.F. Antibacterial activity of Zanthoxylum rhoifolium. Fitoterapia, v.69, n.3, 271-272, 1998.

PAIVA, L.A.F.; RAO, V.S.N.; GRAMOSA, N.V.; SILVEIRA, E.R. Gastroprotective effect of Copaifera langsdorfii oleo-resin on experimental gastric ulcer models in rats. Journal of Ethnopharmacology, v.62, p.73-78, 1998.

PAULA, J.E. de; ALVES, J.L.H. Estudo das estruturas anatômicas e de algumas propriedades físicas da madeira de 14 espécies ocorrentes em áreas de caatinga. Brasil Florestal, v.10, n.43, p.47-58, 1980. 
PAULA, J.E. de; ALVES, J.L.H. Madeiras nativas: anatomia, dendrologia, dendrometria, produção e uso. Brasília: Fundação Mokiti Okada, 1997. 435p.

PEREIRA, J. A. Contribuição para a identificação micrográfica das nossas madeiras. São Paulo: Escola Politécnica de São Paulo, $1933.165 p$. (Boletim, 8).

PERES, M.T.L.P.; MONACHE, F.D.; CRUZ, A.B.; PIZZOLATTI, M.G.; YUNES, R.A. Chemical composition and antimicrobial activity of Croton urucurana Baillon (Euphorbiaceae). Journal of Ethnopharmacology, v.56, p.223-226, 1997.

PERES, M.T.L.P.; MONACHE, F.D.; CRUZ, A.B.; PIZZOLATTI, M.G.; SANTOS, A.R.S.; BEIRITH, A.; CALIXTO, J.B.; YUNES, R.A. Analgesic compounds of Croton urucurana Baillon. Pharmaco-chemical criteria used in their isolation. Phytotherapy Research, v.12, p.209-211, 1998.

PFEIFFER, J.P.H.; VAROSSIEAU, W. W. Classification of the structural elements of the secondary wood of dicotyledons, using decimal indices for classification and identification of wood species. Blumea, v.5, n.3, p.437$489,1946$.

PINHEIRO, A. L.; ALMEIDA, E. C. de. Fundamentos de taxonomia e dendrologia tropical: metodologia dendrológica. Viçosa: SIF, 2000. 3v.

PINHEIRO, A.L.; JESUS, R.M. de; ALMEIDA, E.C. de; CARMO, A.P.T. do. Dendrologia riodocensis I. Gurindiba (Trema micrantha L. Blume). Revista Ceres, v.41, n.233, p.12-18, 1994. 
PINHEIRO, A. L.; SILVA, E. A. M. da; RAMALHO, R. da S. Estudos dendrológicos com vista àregeneração natural de Meliaceae na microrregião de Viçosa, MG. II. Descrição anatômica de quatro espécies. Revista Árvore, v.15, n.2, p.152-163, 1991.

PINHO, R.A.; CAMARGO, T.M. Contribuição ao estudo anatômico do lenho secundário de árvores da flora dos cerrados. III. São Paulo. Brasil. Hoehnea, v.8, p.1-19, 1979.

RAMALHO, R.S. Dendrologia I: termonologia. Viçosa: UFV, 1975, 123p.

RIBEIRO, E.B.P.; LUZ, C.N.R. A Trema micrantha como matéria-prima para produção de celulose. Acta Amazonica, v.3, n.3, p.45-50, 1973.

SANTOS, E. dos; MARANGON, L. C.; RAMALHO, R. da S. Levantamento dendrológico da Bacia do Rio São Bartolomeu, Viçosa - MG. Revista Ceres, v.45, n.260, p.339-349, 1998.

SHIMOYA, C.; RAMALHO, R. da S. O uso do trado na coleta de amostras para estudo anatômico da madeira. Revista Ceres, v.16, n.88, p.70-80, 1969.

SILVA, A. C. Introdução à anatomia da madeira. Manaus: Instituto de Tecnologia da Amazônia, 1987. 128p.

SIMONI, I.C.; MUNFORD, V.; FELICIO, J.D.; LINS, A.P. Antiviral activity of crude extracts of Guarea guidonia. Brazilian Journal of Medical and Biological Reserach, v.29, p.647-650, 1996.

STOREY, C.; SALEM, J.I. Lay use of amazonian plants for the treatment of tuberculosis. Acta Amazonica, v.27, n.3, p. 175-182, 1997. 
TOMAZELLO FILHO, M.; CHIMELO, J.P.; GARCIA, P.V. Madeiras de espécies florestais do Estado do Maranhão. II. Caracterização anatômica. São Paulo: IPT, n.165, 1984.

WERLE, A.A.; PAGLIOSA, F.M.; YOSHIDA, M.; GOTTLIEB, O.R. Alcalóides aporfínicos de Ocotea puberula (Lauraceae). Ciência e Cultura, v.39, n.7, p.520-521, 1987.

WHEELER, E.A.; PEARSON, R.G.; LA PASHA, C.A.; ZACK, T.; HATLEY,W. Computer-aided wood identification - reference manual. Madison: North Carolina Agricultural Research Service, Department of Wood and Paper Science, 1986. 160p.

WHER, N. C.; TOMAZELLO FILHO, M. Caracterização dos anéis de crescimento de Araucaria angustifolia Bert. O. Ktze, através de densitometria de raios X. Scientia Forestalia, v.58, p.15-28, 2000.

WILSON, E.O.; PETER, F.M. Biodiversity. 20 ed. Washington: National Academic Press, 1995. 521p. 


\section{APÊNDICE}



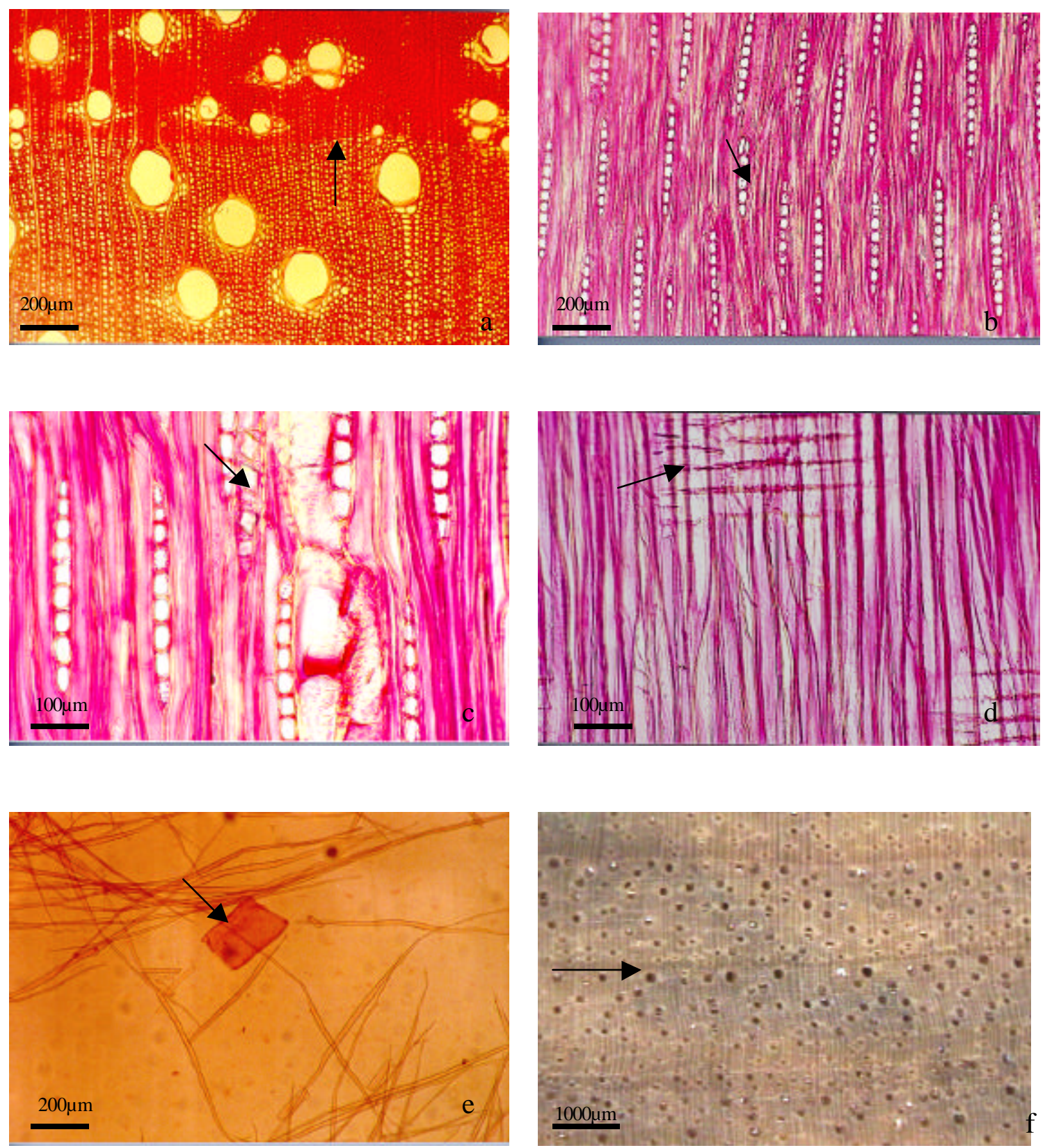

Figura 1 - Araribá, Cebtrolobium sp.

a) plano transversal - camada de crescimento (seta); b) plano longitudinal tangencial - raio unisseriado (seta); c) plano longitudinal tangencial - cristais em células do parênquima axial (seta); d) plano longitudinal radial - raio homocelular (seta); e) elemento de vaso (seta); f) plano transversal - camada de crescimento (seta). 

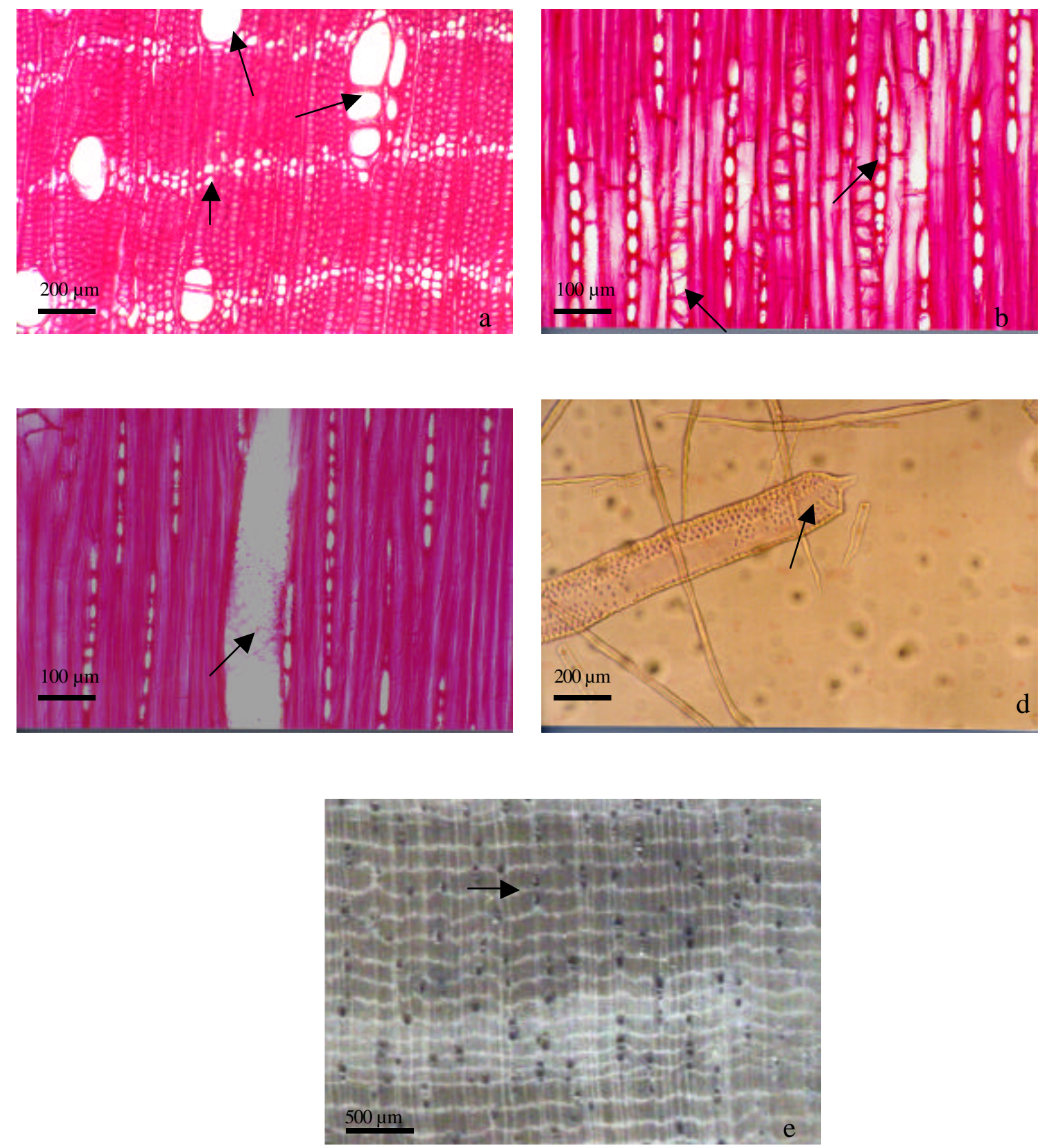

Figura 2 - Canxim, Pachystroma ilicifolium

a) plano transversal - parênquima axial (seta); b) plano longitudinal tangencial - raio unisseriado (seta), cristais em células do parênquima axial (seta); c) plano longitudinal tangencial - pontoações intervasculares (seta); d) elemento de vaso (seta); e) plano transversal - parênquima axial (seta). 

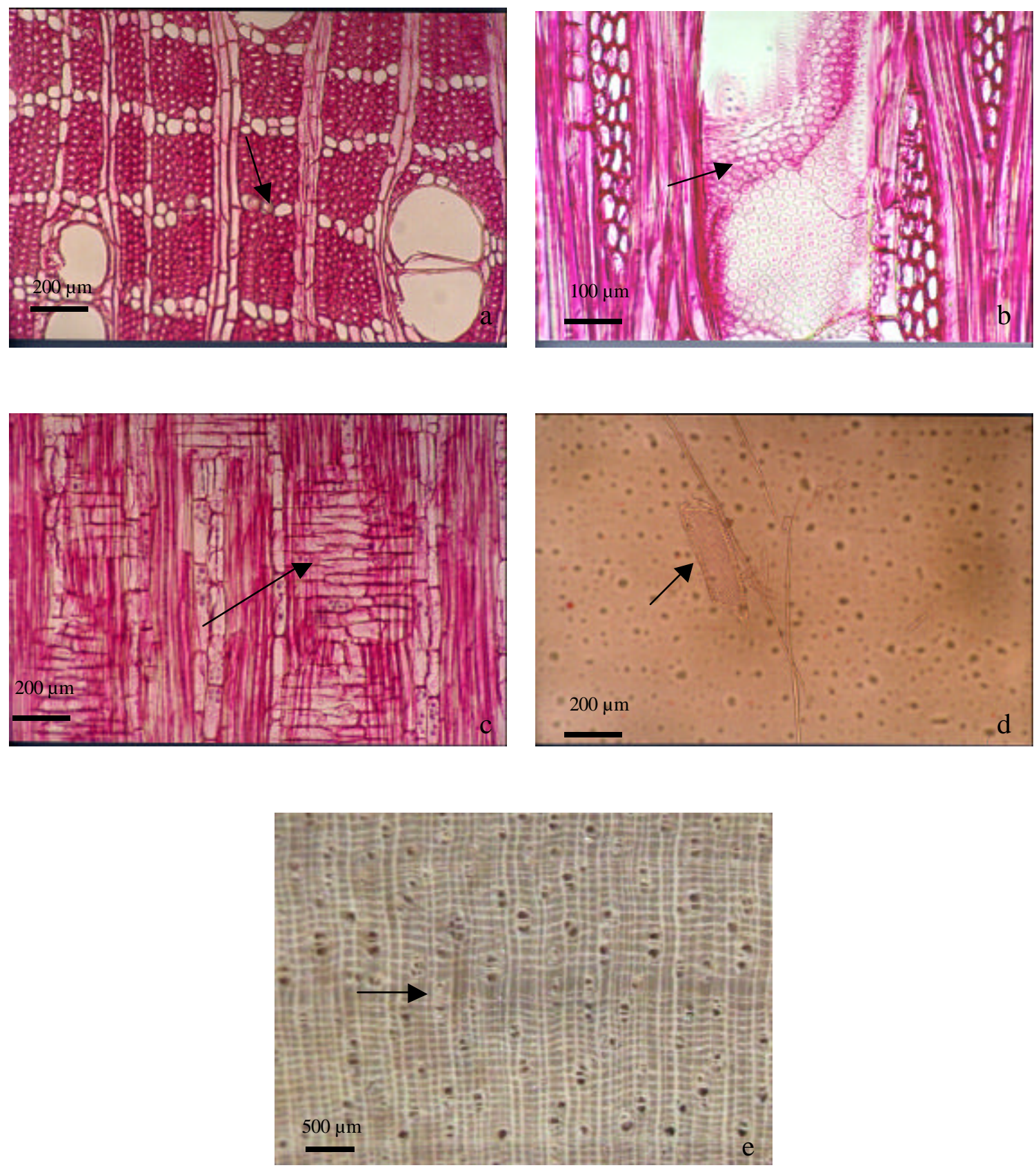

Figura 3 - Jequitibá-branco, Cariniana estrellensis $\quad \Rightarrow$

a) plano transversal - parênquima axial (seta); b) plano longitudinal tangencial - pontoações intervasculares (seta); c) plano longitudinal radial - raio homocelular (seta); d) elemento de vaso (seta); e) plano transversal - camada de crescimento (seta). 

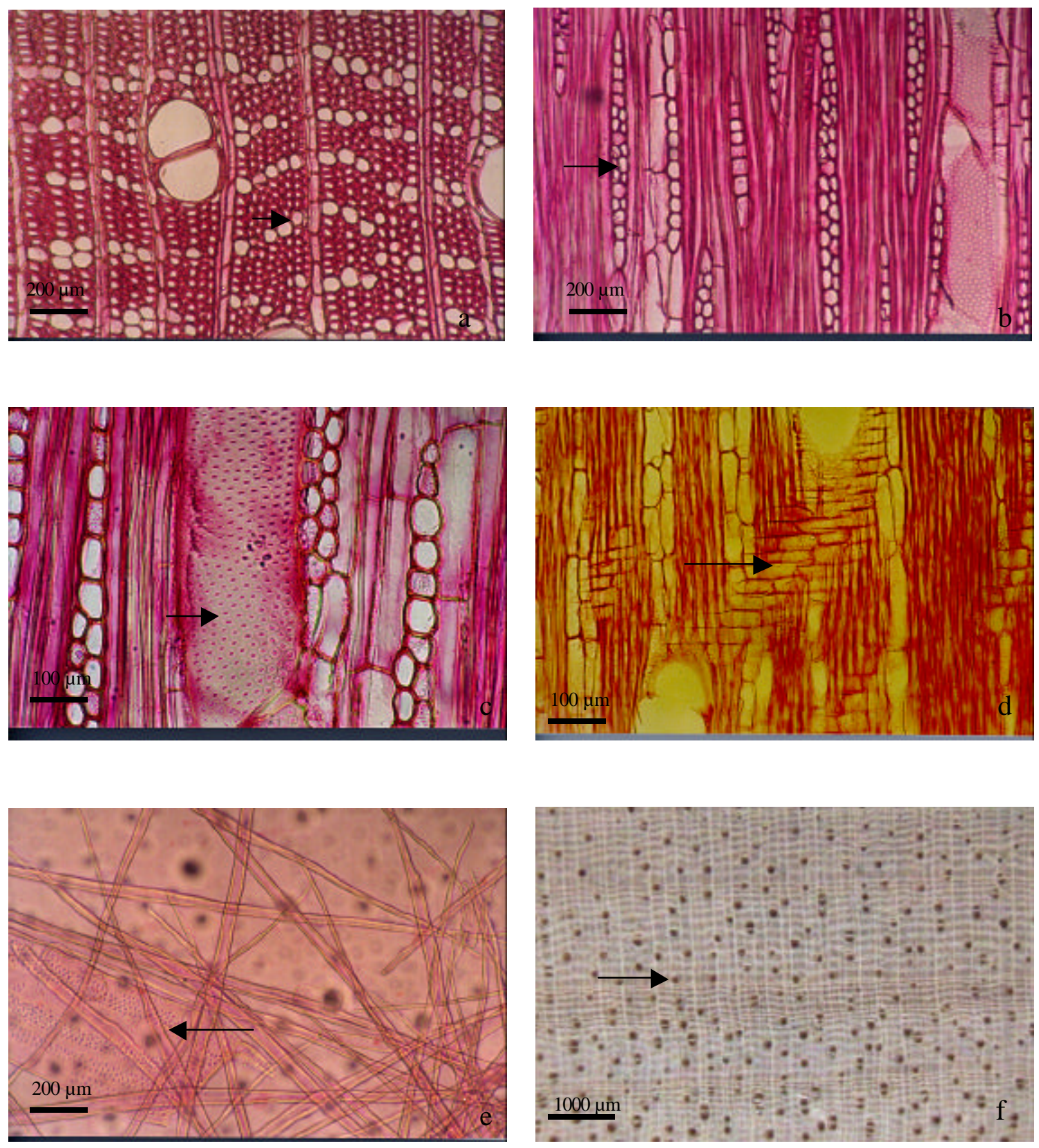

Figura 4 - Jequitibá-rosa, Cariniana legalis

a) plano transversal - parênquima axial (seta); b) plano longitudinal tangencial - raio bisseriado (seta); c) plano longitudinal tangencial - pontoações intervasculares (seta); d) plano longitudinal radial - raio homocelular; e) elemento de vaso (seta); f) plano transversal - camada de crescimento (seta). 

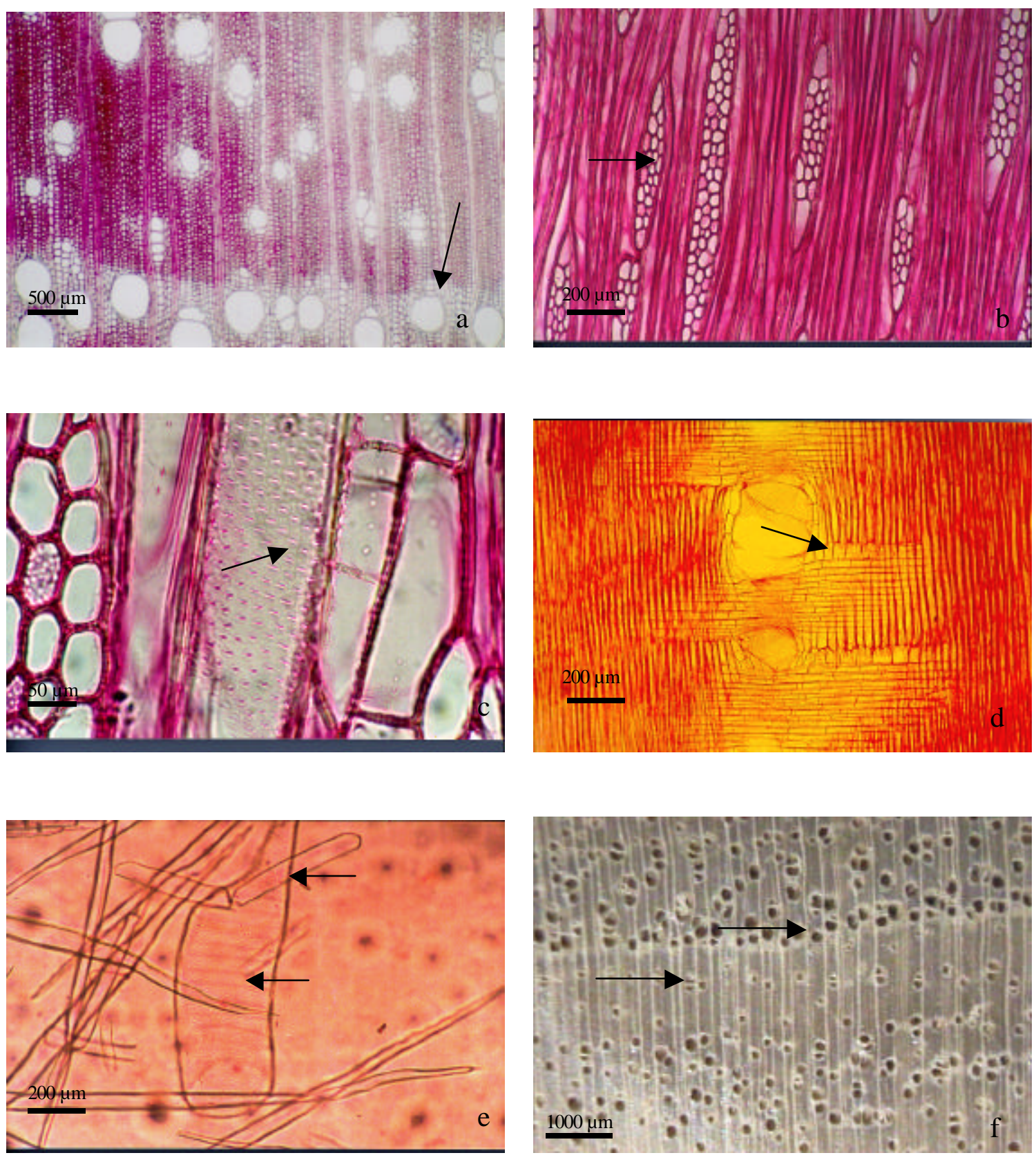

Figura 5 - Fruta-de-pomba, Erythroxylum sp.

a) plano transversal - parênquima axial (seta); b) plano longitudinal tangencial - raio trisseriado (seta); c) plano longitudinal tangencial - pontoações intervasculares (seta); d) plano longitudinal radial - raio heterocelular; e) elemento de vaso (seta); f) plano transversal - anel poroso (seta). 

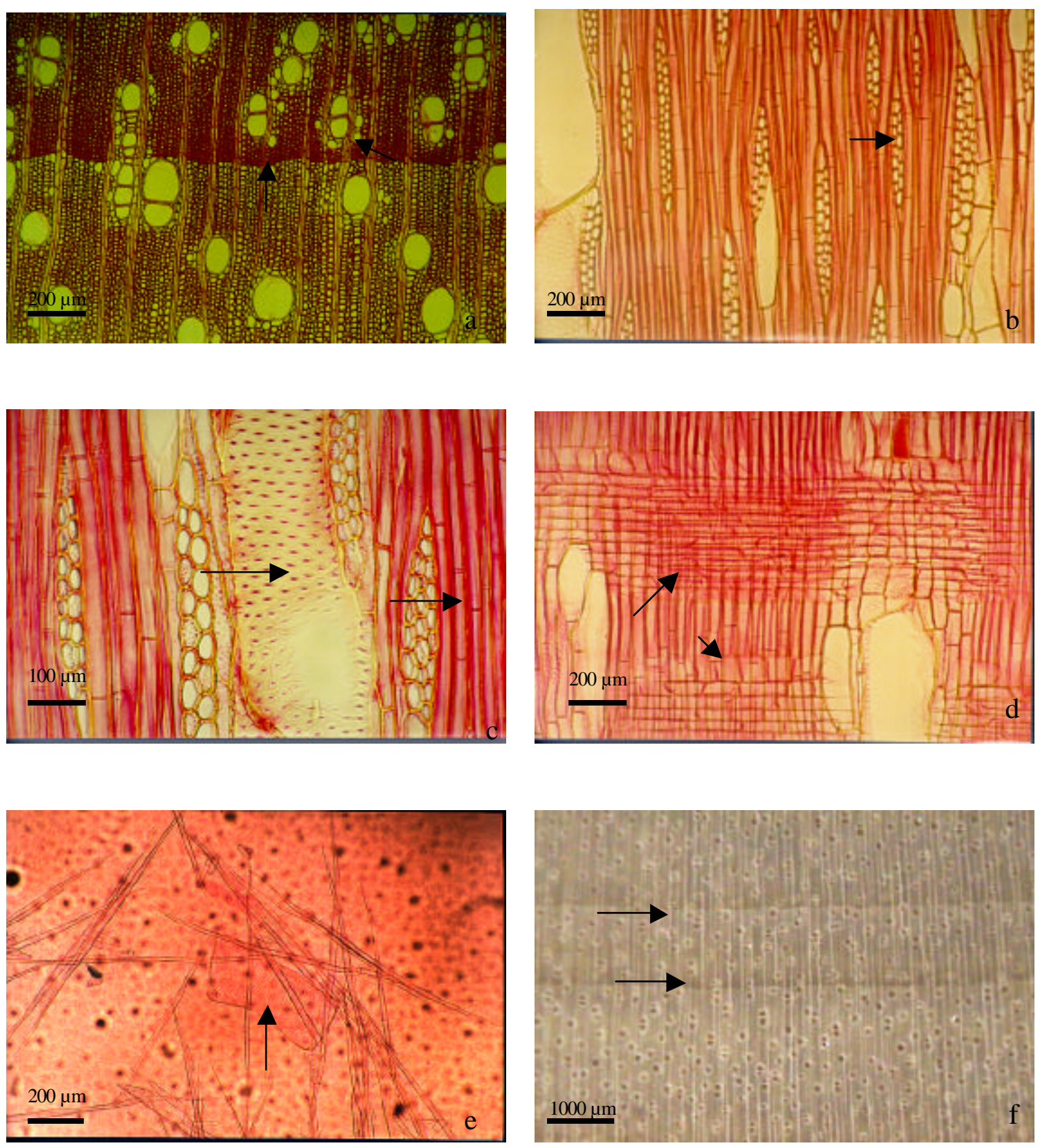

Figura 6 - Imbuia, Ocotea porosa

a) plano transversal - camada de crescimento (seta); b) plano longitudinal tangencial - raio bisseriado (seta); c) plano longitudinal tangencial - pontoações intervasculares (seta); d) plano longitudinal radial - raio heterocelular; e) elemento de vaso (seta); f) plano transversal - camadas de crescimento(seta). 

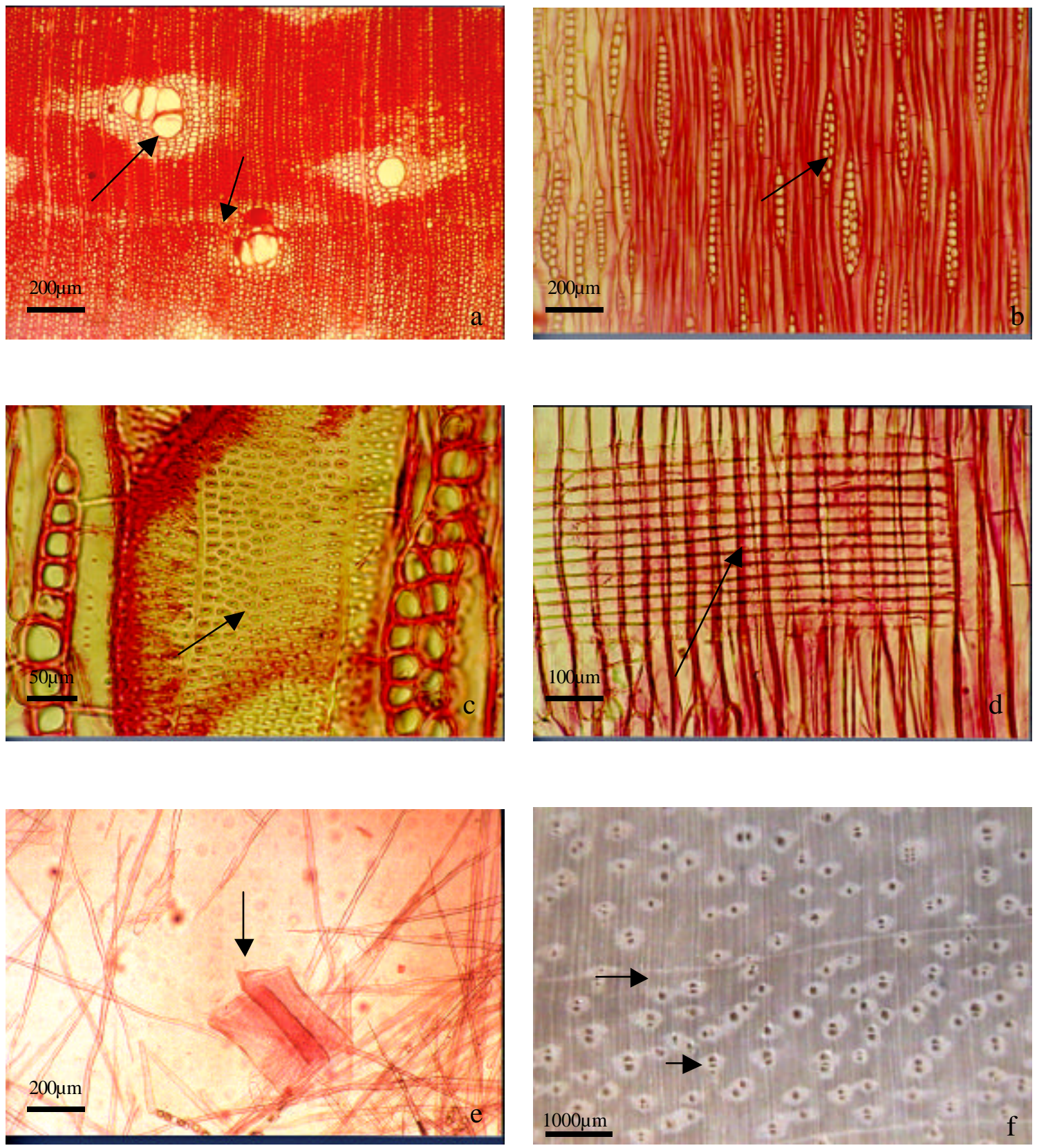

Figura 7 - Canafístula, Cassia ferruginea

a) plano transversal - parênquima axial (setas); b) plano longitudinal tangencial - raio bisseriado (seta); c) plano longitudinal tangencial - pontoações intervasculares (seta); d) plano longitudinal radial - raio homocelular; e) elementos de vaso (seta); f) plano transversal - camada de crescimento(seta), parênquima axial (seta). 

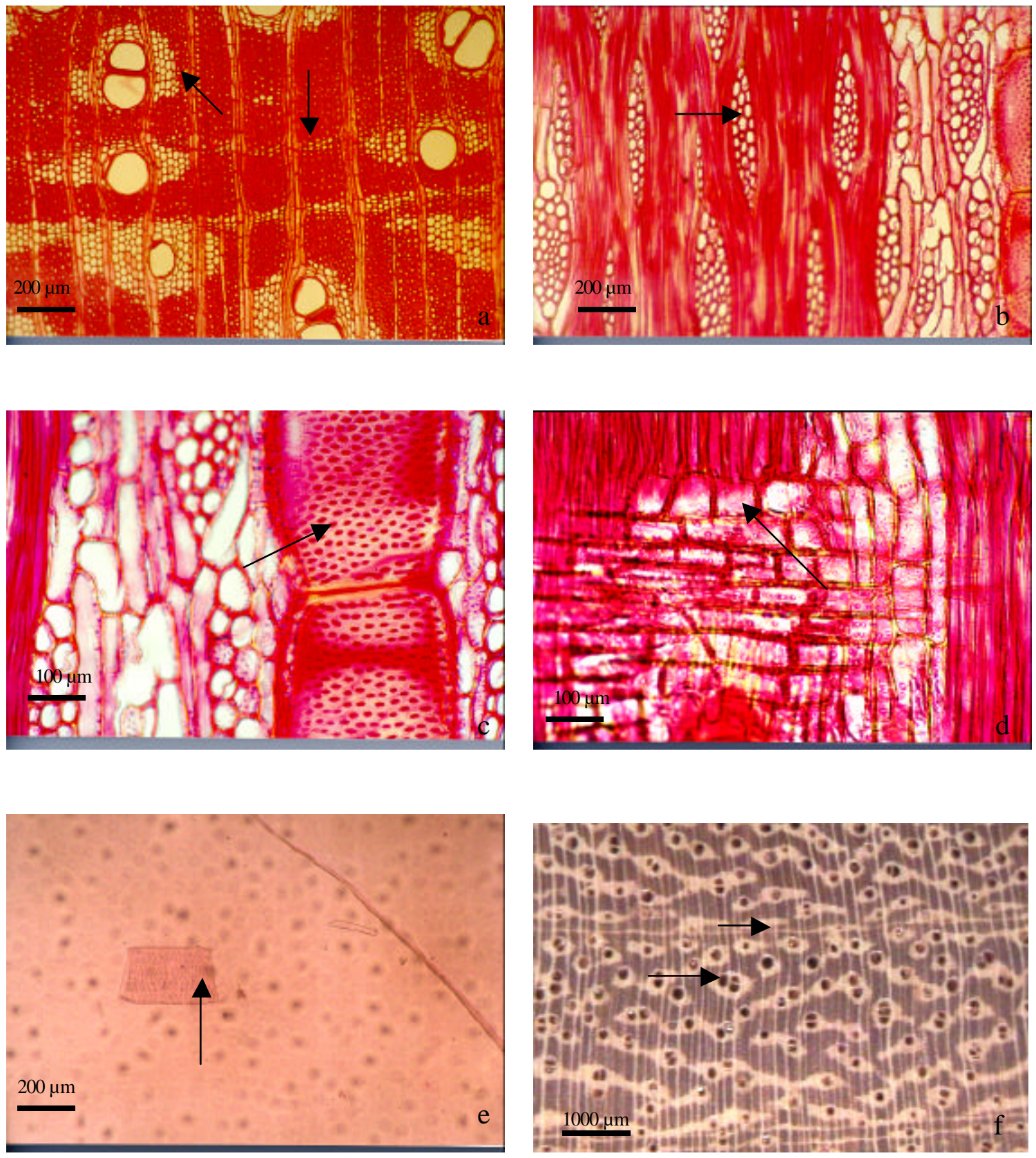

Figura 8 - Pau-pereira, Platycyamus regnelli

a) plano transversal - parênquima axial (setas); b) plano longitudinal tangencial - raio trisseriado (seta); c) plano longitudinal tangencial - pontoações intervasculares (seta); d) plano longitudinal radial - raio heterocelular; e) elemento de vaso (seta); f) plano transversal - camada de crescimento (seta), parênquima axial (seta). 

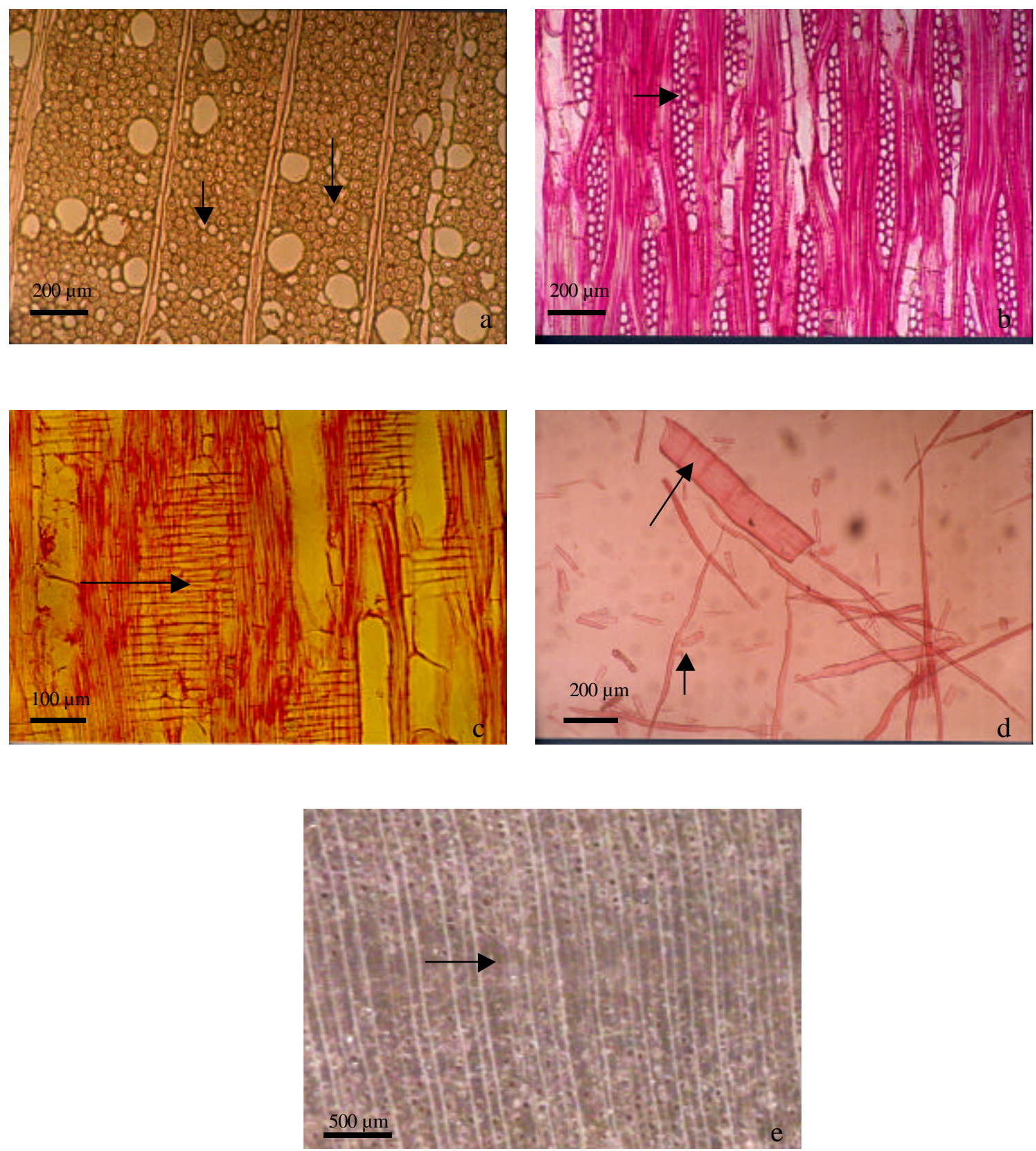

Figura 9 - Peroba-rosa, Aspidosperma polyneuron

a) plano transversal - célula de parênquima axial (setas); b) plano longitudinal tangencial raio trisseriado (seta); c) plano longitudinal radial - raio homocelular; d) elemento de vaso (seta), célula de parênquima (seta); e) plano transversal - camada de crescimento (seta). 

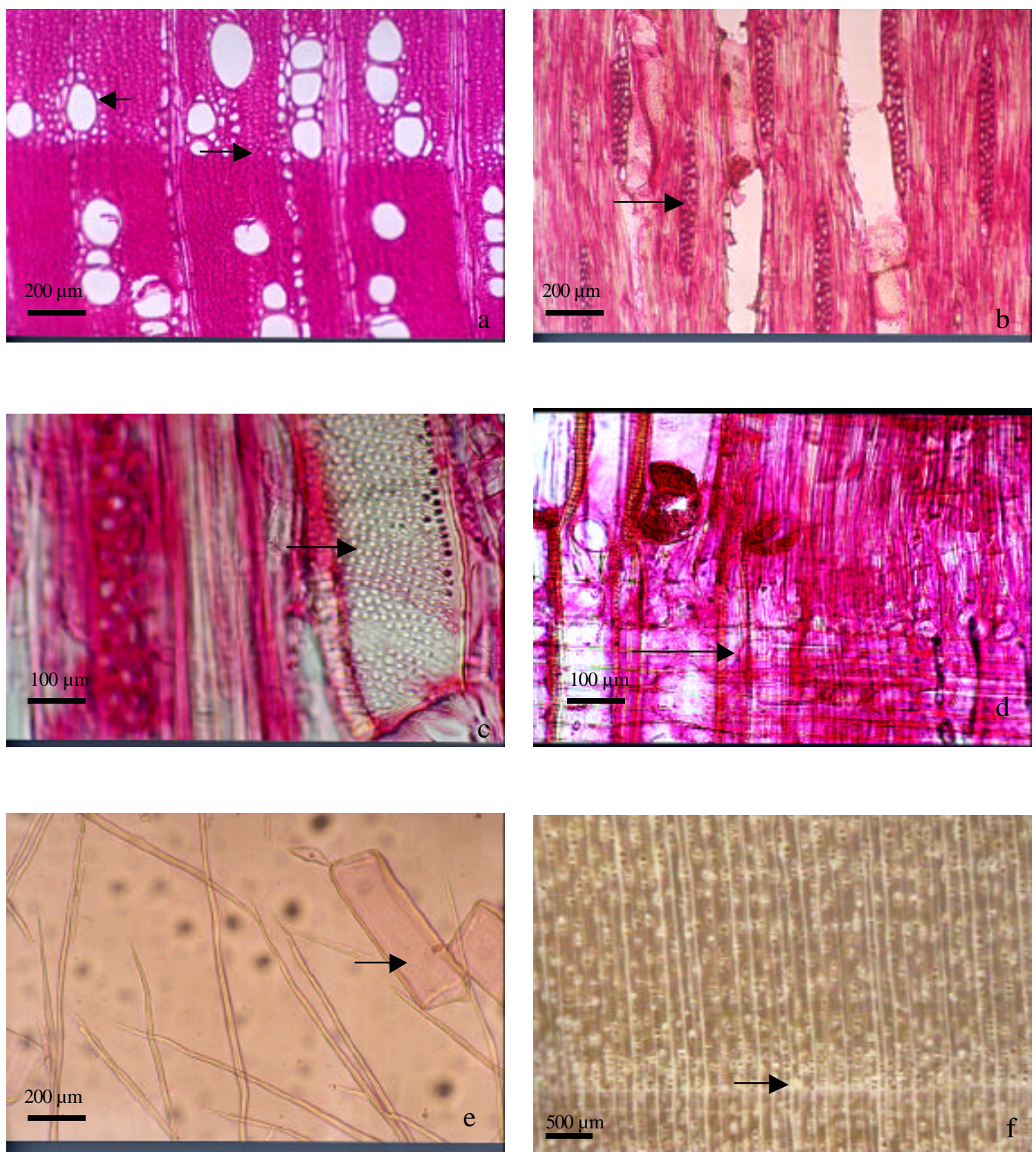

Figura 10 - Guarantã, Esenbeckia leiocarpa

a) plano transversal - parênquima axial (seta), camada de crescimento (seta); b) plano longitudinal tangencial - raio trisseriado (seta); c) plano longitudinal tangencial - pontoações intervasculares (seta); d) plano longitudinal radial - raio heterocelular; e) elemento de vaso (seta); f) plano transversal - camada de crescimento (seta). 

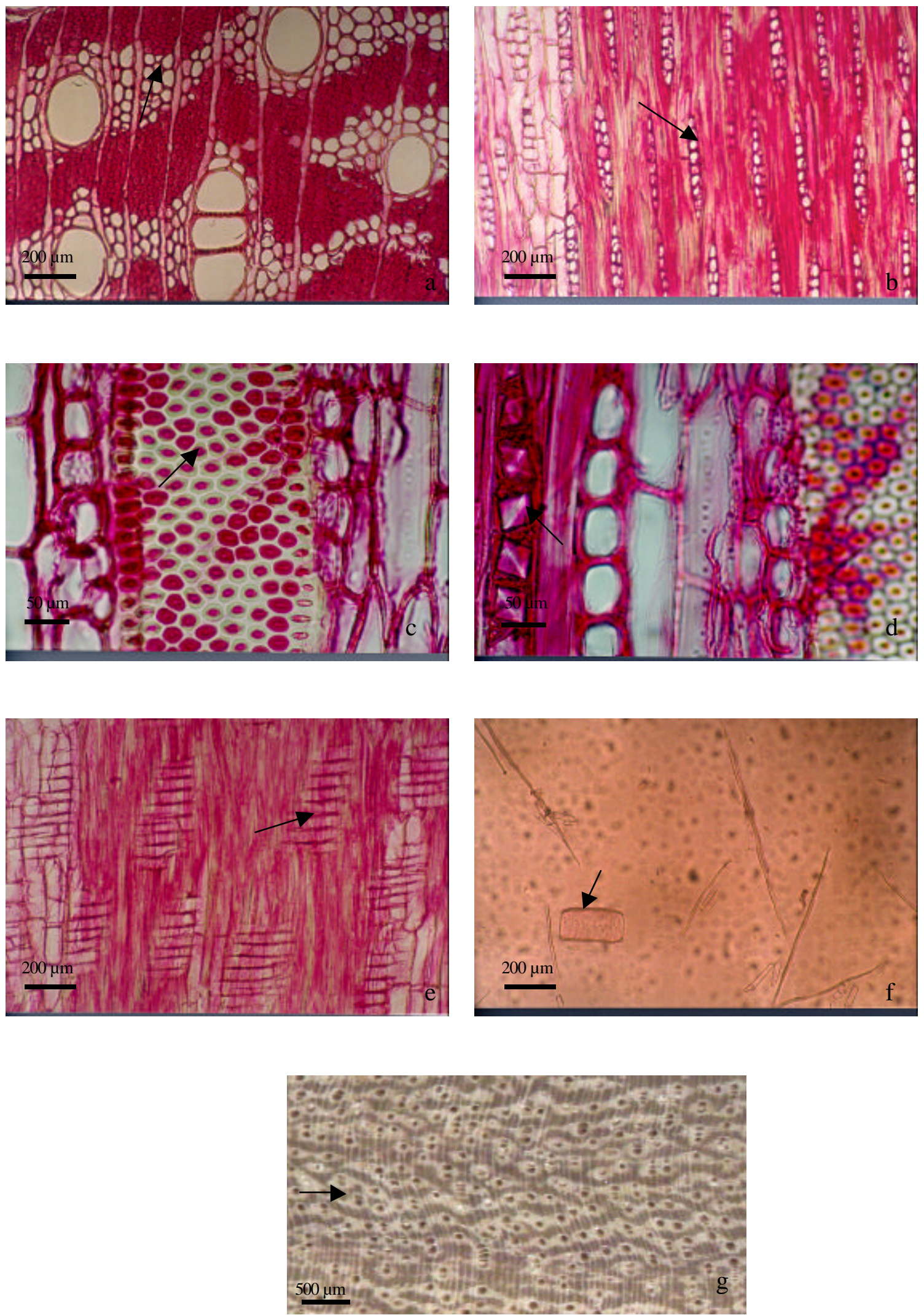

Figura 11 - Cumaru, Dipteryx sp.

a) plano transversal - parênquima axial (seta); b) plano longitudinal tangencial - raio unisseriado (seta); c) plano longitudinal tangencial pontoações intervasculares (seta); d) plano longitudinal tangencial - cristais em células do parênquima axial; e) plano longitudinal radial - raio homocelular (seta); f) elemento de vaso (seta); g) plano transversal - parênquima axial (seta). 

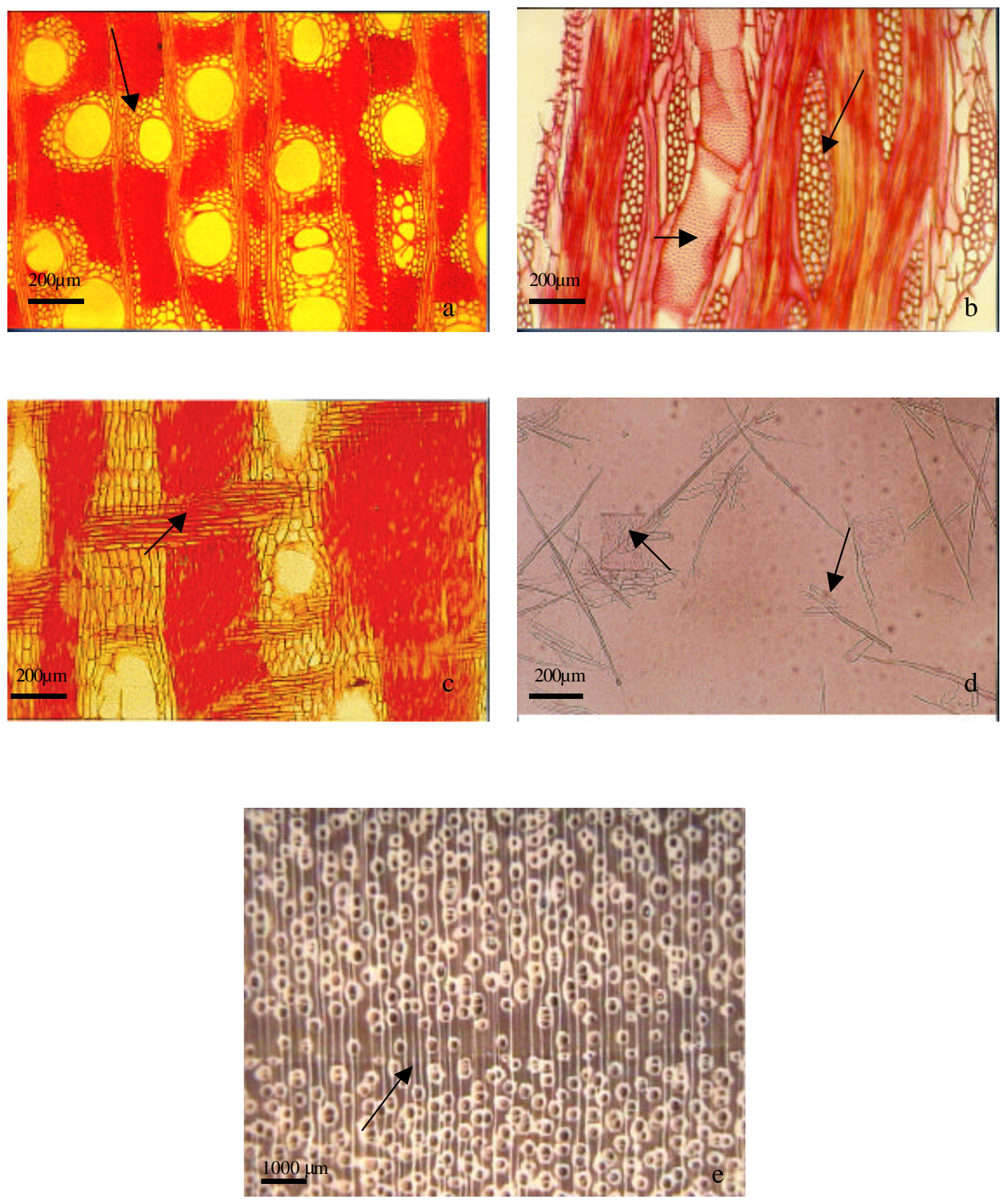

Figura 12 - Angico-preto, Piptadenia macrocarpa

a) plano transversal - parênquima axial (seta); b) plano longitudinal tangencial - vaso (seta), raio multisseriado (seta); c) plano longitudinal radial - raio homocelular; d) elemento de vaso (seta); e) plano transversal - camada de crescimento (seta). 

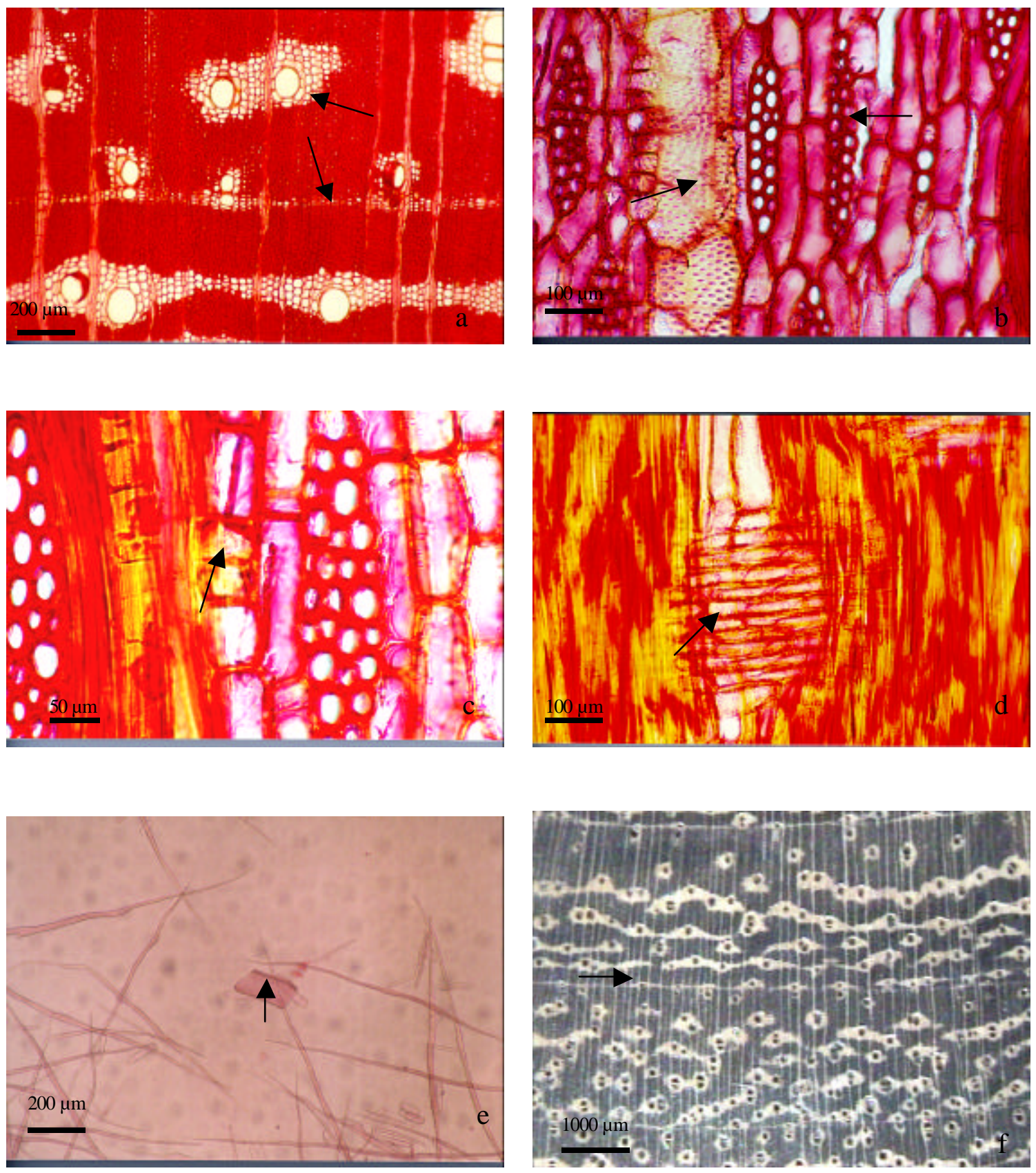

Figura 13 - Pau-ferro, Caesalpinia ferrea

a) plano transversal - parênquima axial (setas); b) plano longitudinal tangencial pontoações intervasculares (seta), raio bisseriado (seta); c) plano longitudinal tangencial cristais em células do parênquima axial (seta); d) plano longitudinal radial - raio homocelular; e) elemento de vaso (seta); f) plano transversal - camada de crescimento (seta). 

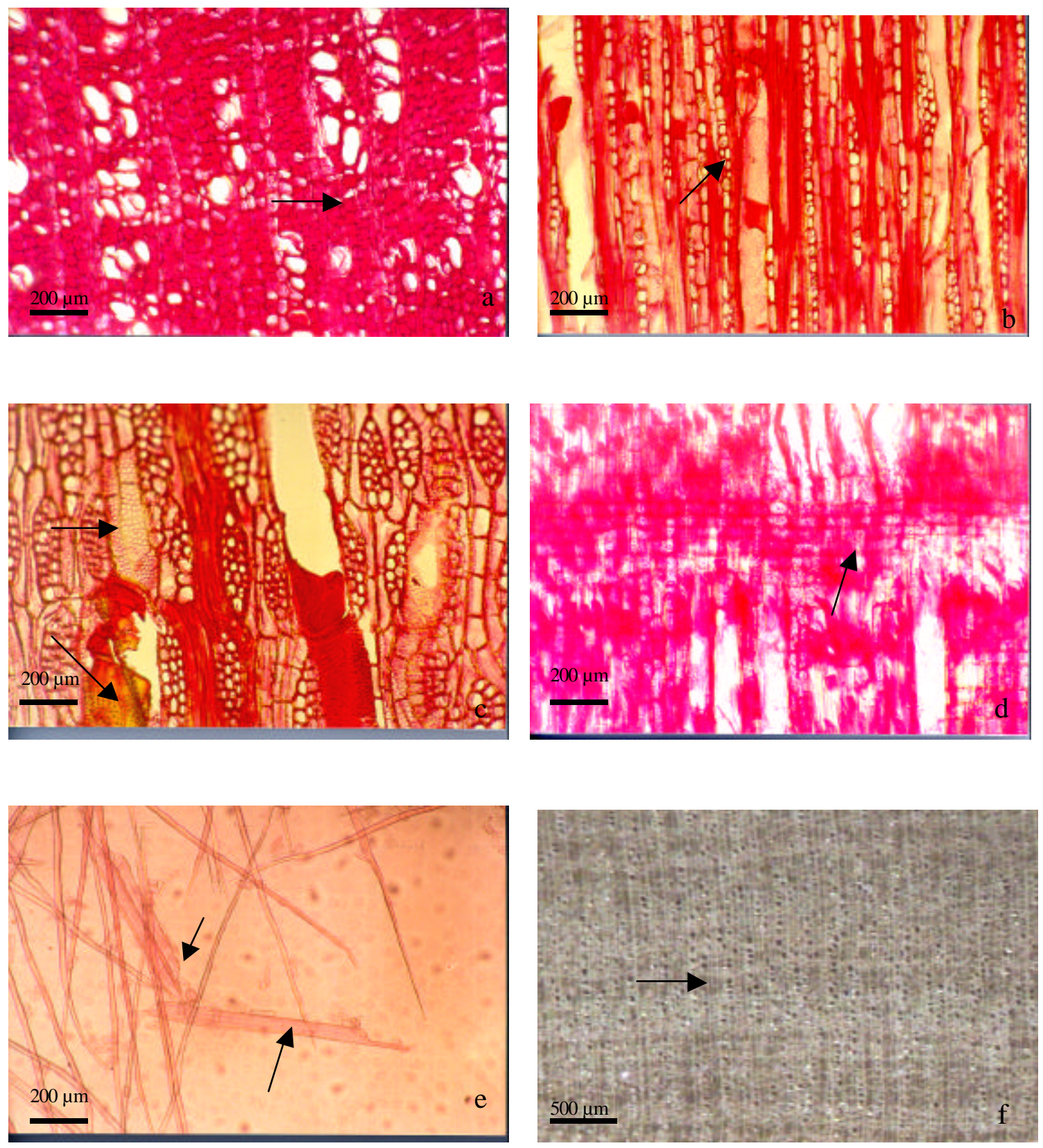

Figura 14 - Guaraiúva, Securinega guarayuva

a) plano transversal - parênquima axial (seta); b) plano longitudinal tangencial -raio bisseriado (seta); c) plano longitudinal tangencial - pontoações intervasculares (seta); d) plano longitudinal radial - raio heterocelular; e) elementos de vaso (setas); f) plano transversal - camada de crescimento (seta). 

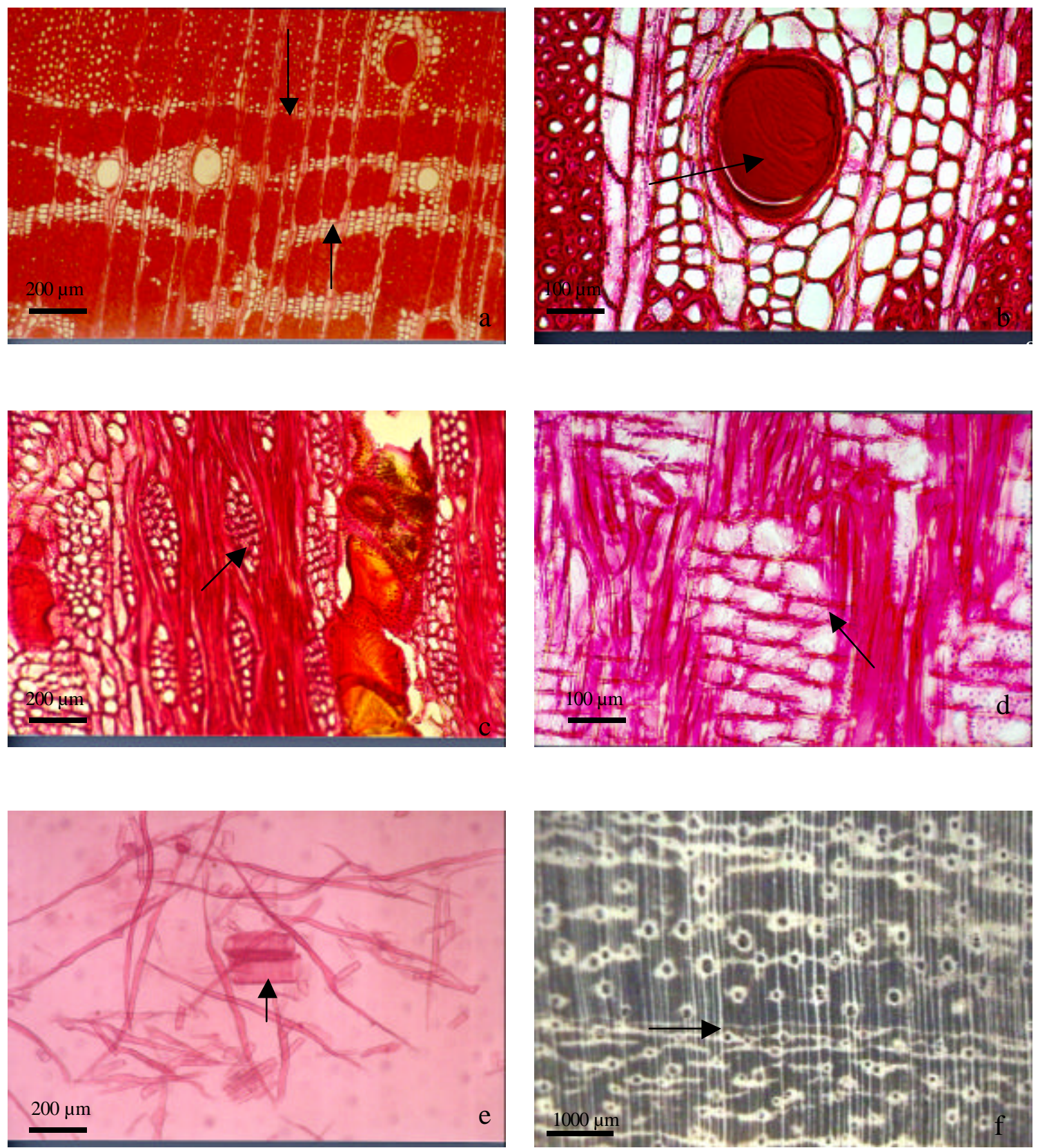

Figura 15 - Jacarandá-paulista, Machaerium villosum

a) plano transversal - parênquima axial (setas); b) plano transversal - vaso (seta); c) plano longitudinal tangencial -raio trisseriado (seta); d) plano longitudinal radial - raio heterocelular (seta); e) elementos de vaso (seta); f) plano transversal - camada de crescimento (seta). 

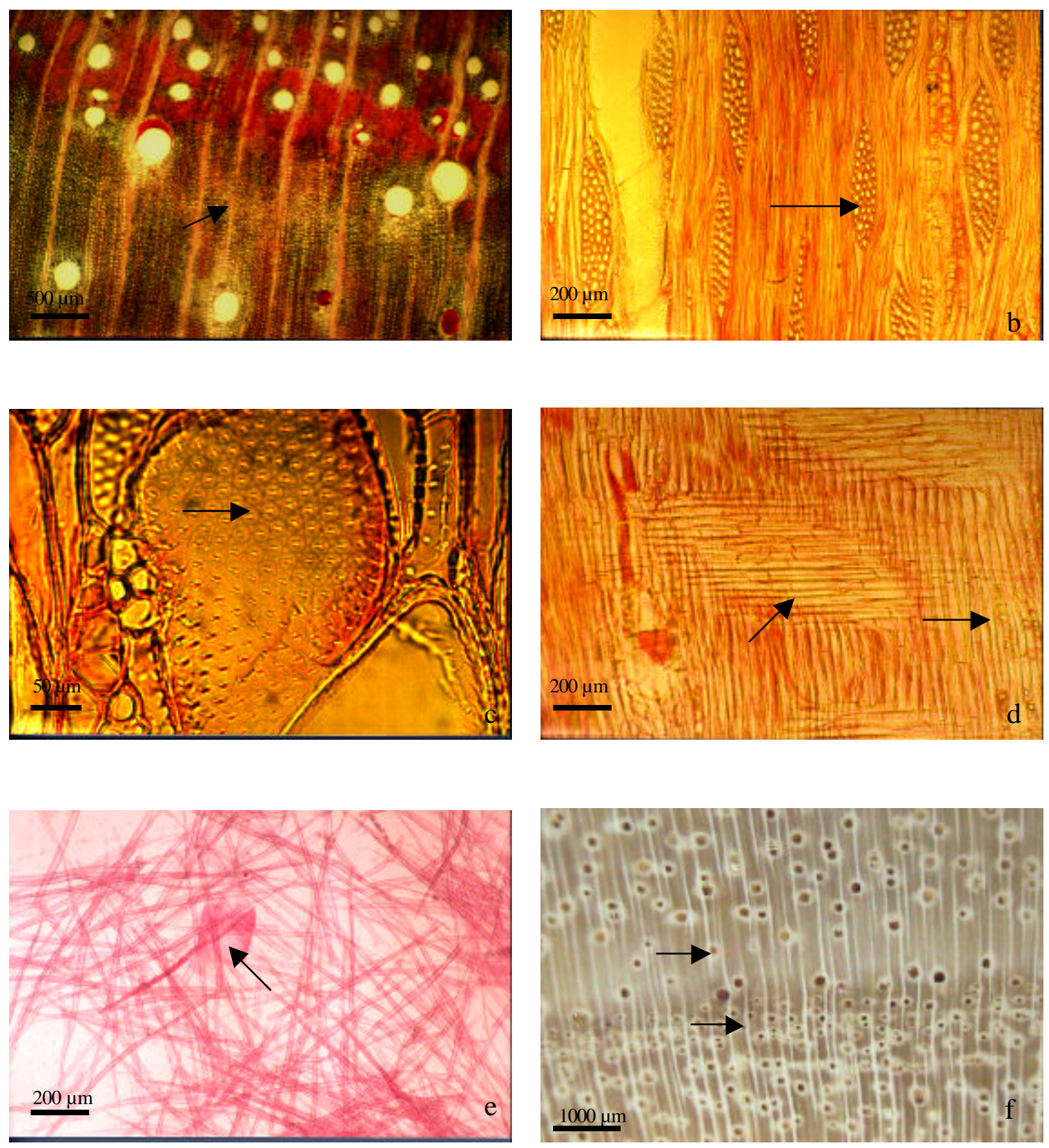

Figura 16 - Pau-jacaré, Piptadenia gonoacantha

a) plano transversal - camada de crescimento (seta); b) plano longitudinal tangencial -raio multisseriado (seta); c) plano longitudinal tangencial - pontoações intervasculares (seta); d) plano longitudinal radial - raio homocelular (seta); e) elemento de vaso (seta); f) plano transversal - anel semi-poroso (seta). 

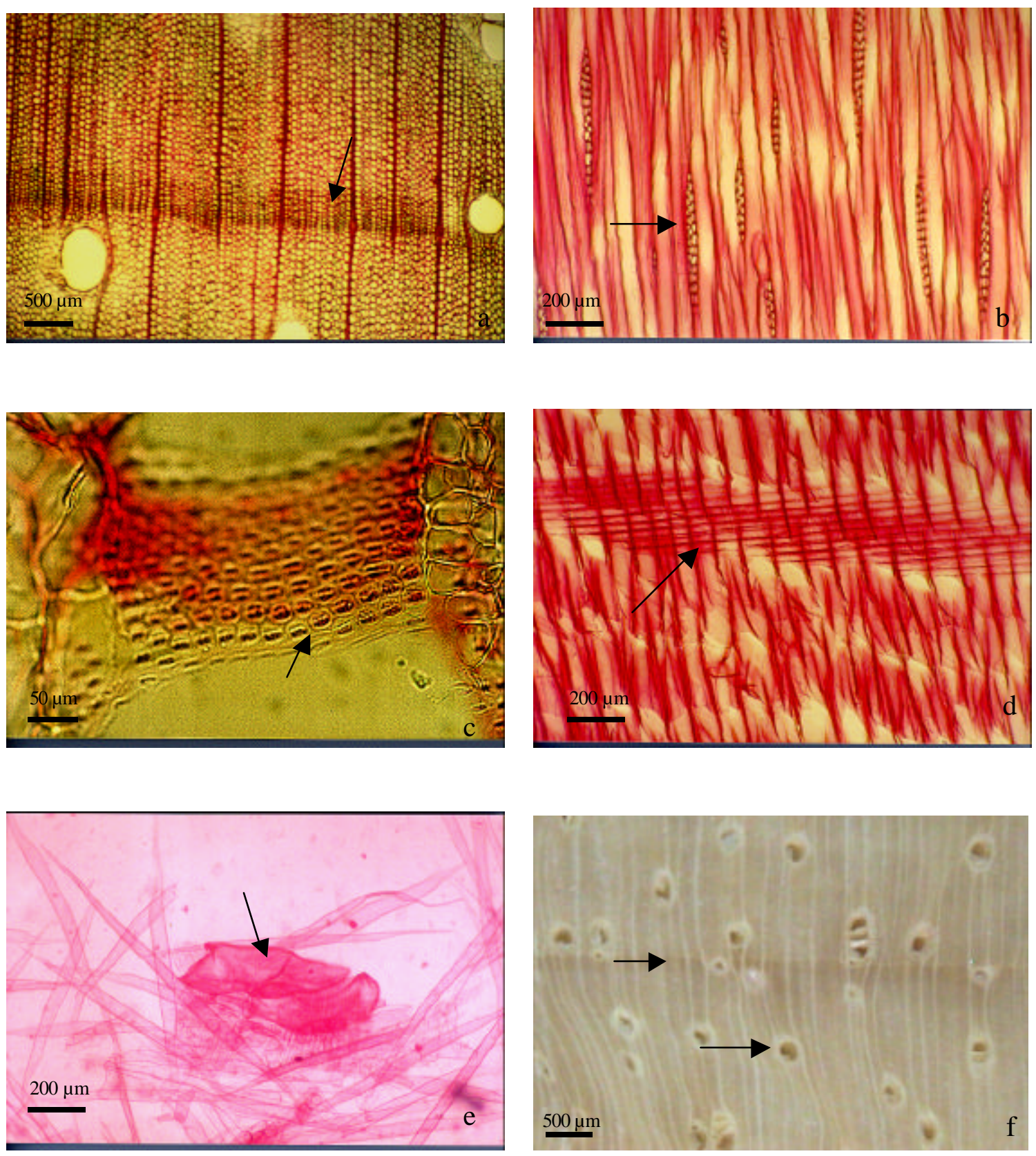

Figura 17 - Guapuruvu, Schizolobium parahyba

a) plano transversal - camada de crescimento (seta); b) plano longitudinal tangencial -raio bisseriado (seta); c) plano longitudinal tangencial - pontoações intervasculares (seta); d) plano longitudinal radial - raio homocelular (seta); e) elementos de vaso (seta); f) plano transversal - camada de crescimento (seta), parênquima axial (seta). 

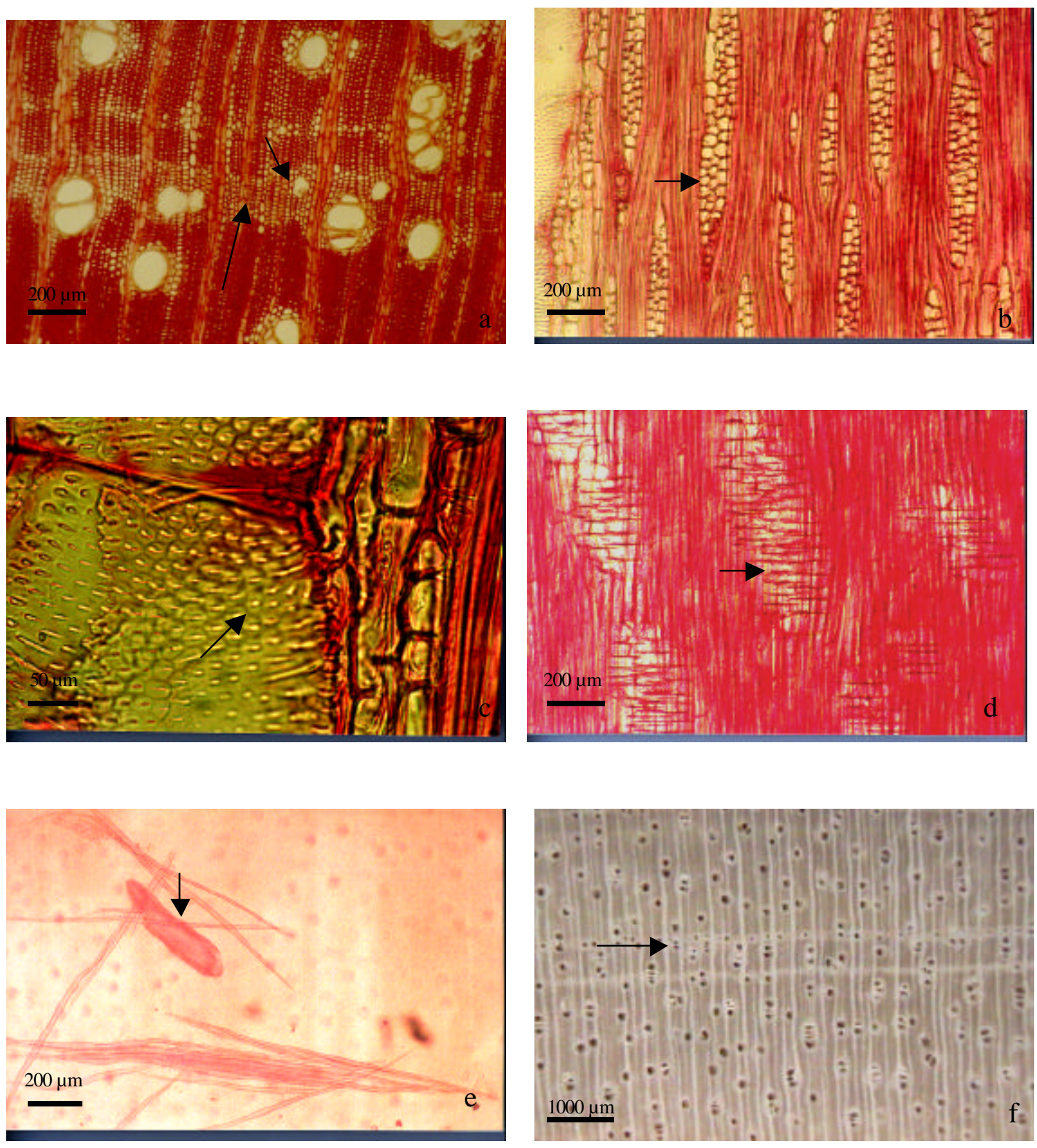

Figura 18 - Copaíba, Copaifera langsdorfii

a) plano transversal - parênquima axial (seta), canal secretor axial (seta); b) plano longitudinal tangencial -raio trisseriado (seta); c) plano longitudinal tangencial - pontoações intervasculares (seta); d) plano longitudinal radial - raio heterocelular (seta); e) elemento de vaso (seta); f) plano transversal - camada de crescimento (seta). 

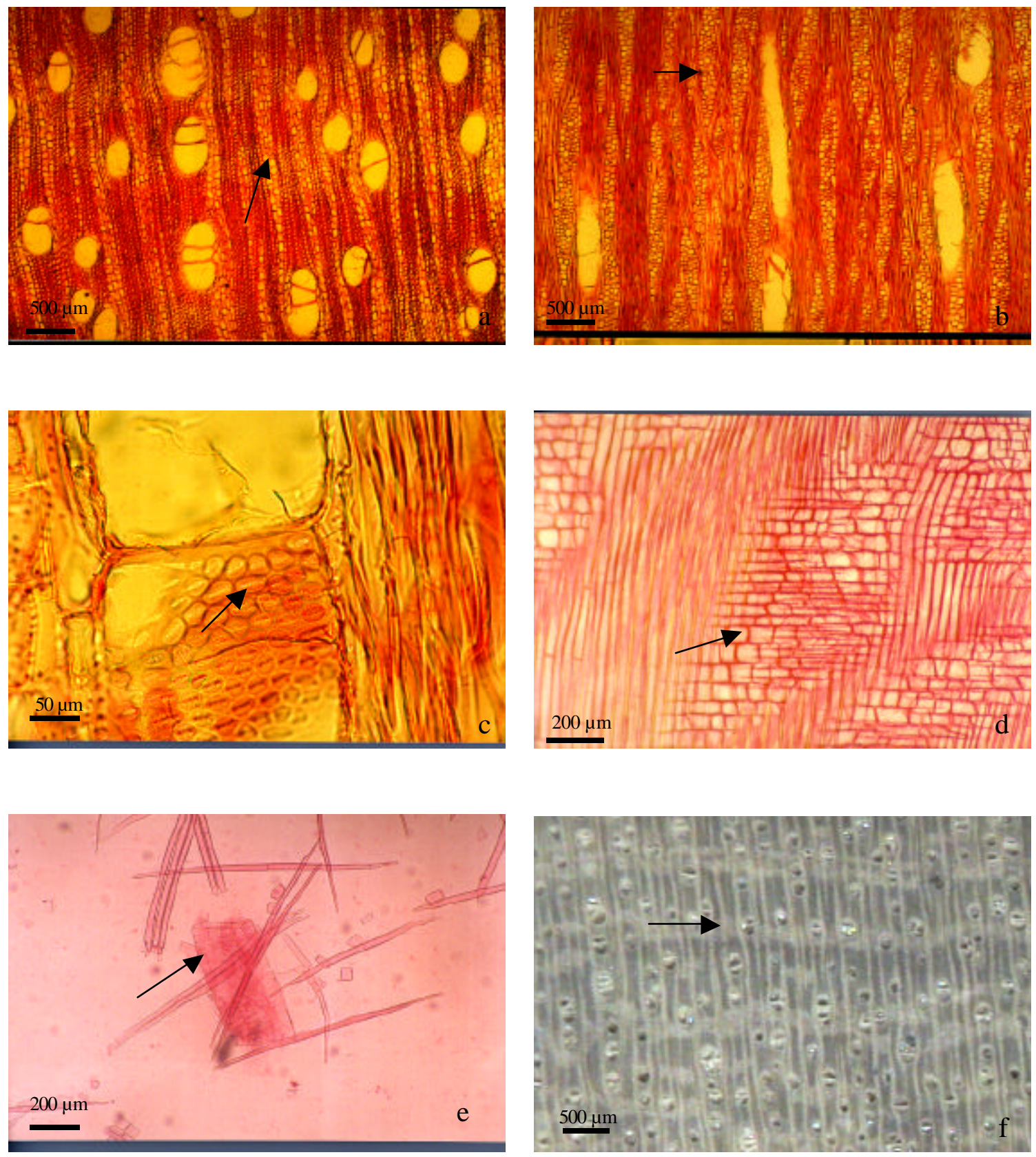

Figura 19 - Quaresmeira, Tibouchina granulosa

a) plano transversal - raio (seta); b) plano longitudinal tangencial - raio multisseriado (seta);

c) plano longitudinal tangencial - pontoações intervasculares (seta); d) plano longitudinal radial - raio heterocelular (seta); e) elemento de vaso (seta); f) plano transversal parênquima axial (seta). 

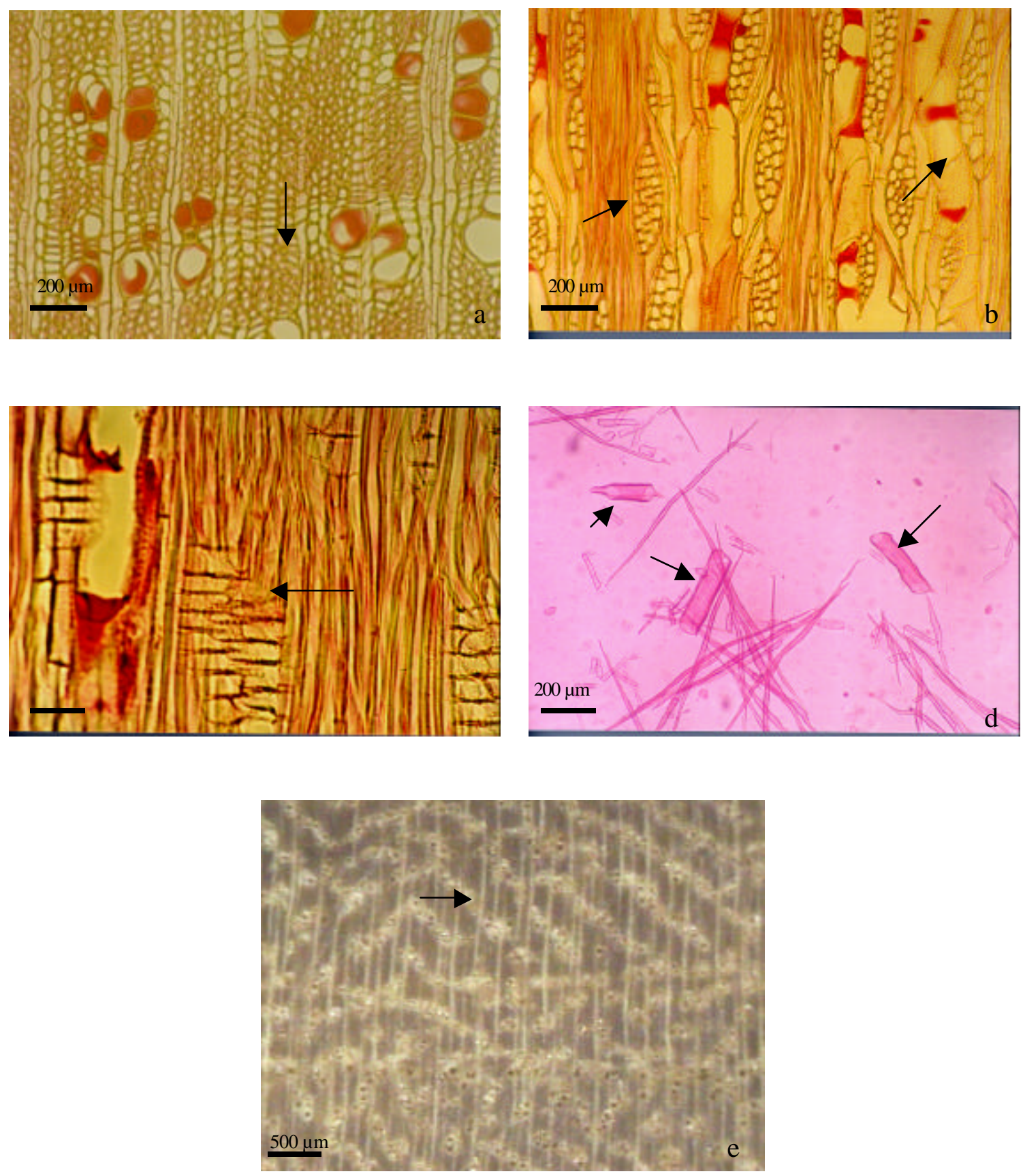

Figura 20 - Cambará, Gochnatia polymorpha

a) plano transversal - parênquima axial (seta); b) plano longitudinal tangencial -raio trisseriado (seta); c) plano longitudinal radial - raio homocelular (seta); d) elementos de vaso (setas); e) plano transversal - parênquima axial (seta). 

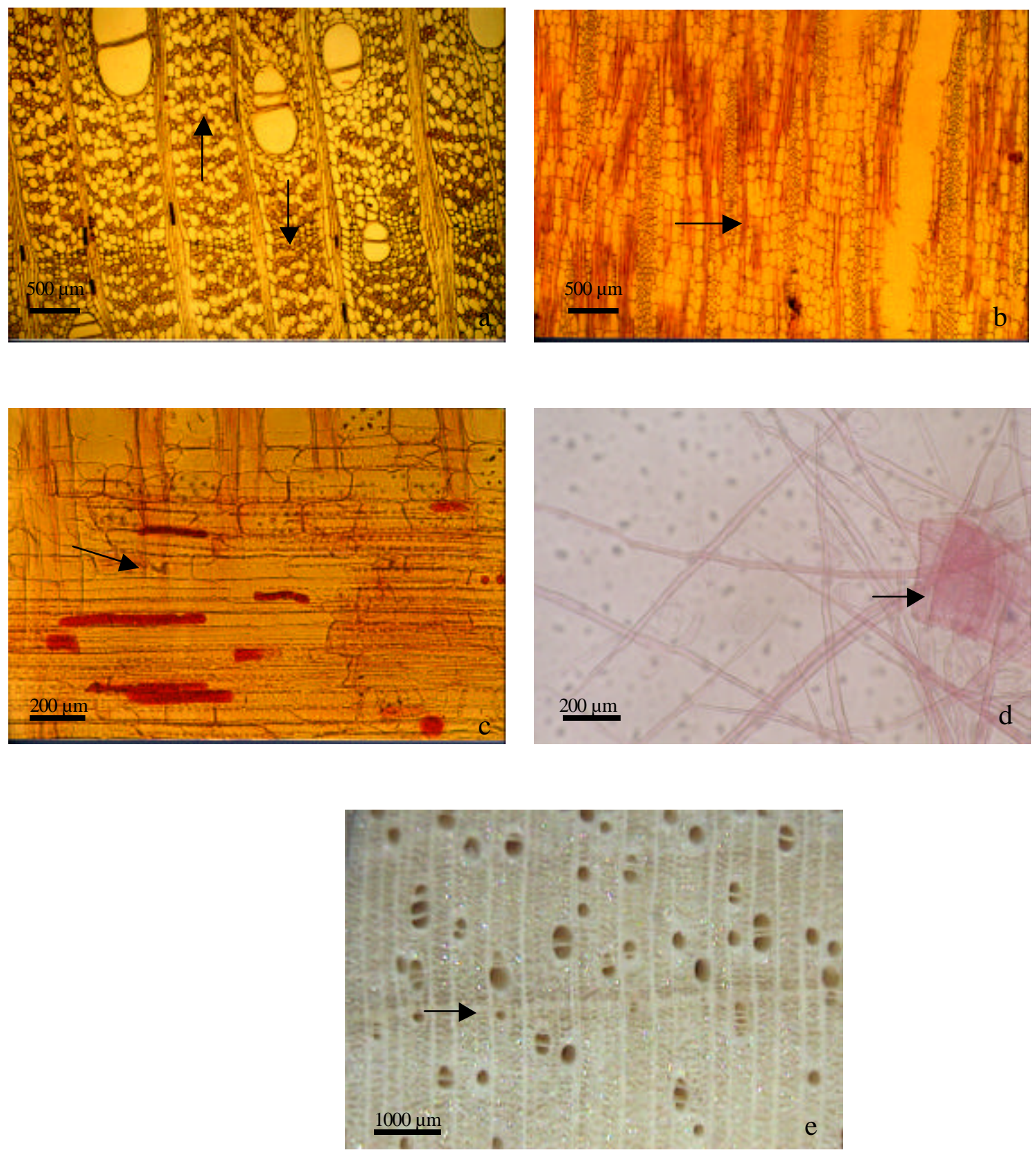

Figura 21 - Paineira, Chorisia speciosa

a) plano transversal - parênquima axial (seta); b) plano longitudinal tangencial -raio multisseriado (seta); c) plano longitudinal radial - raio homocelular (seta); d) elemento de vaso (seta); e) plano transversal - camada de crescimento (seta). 

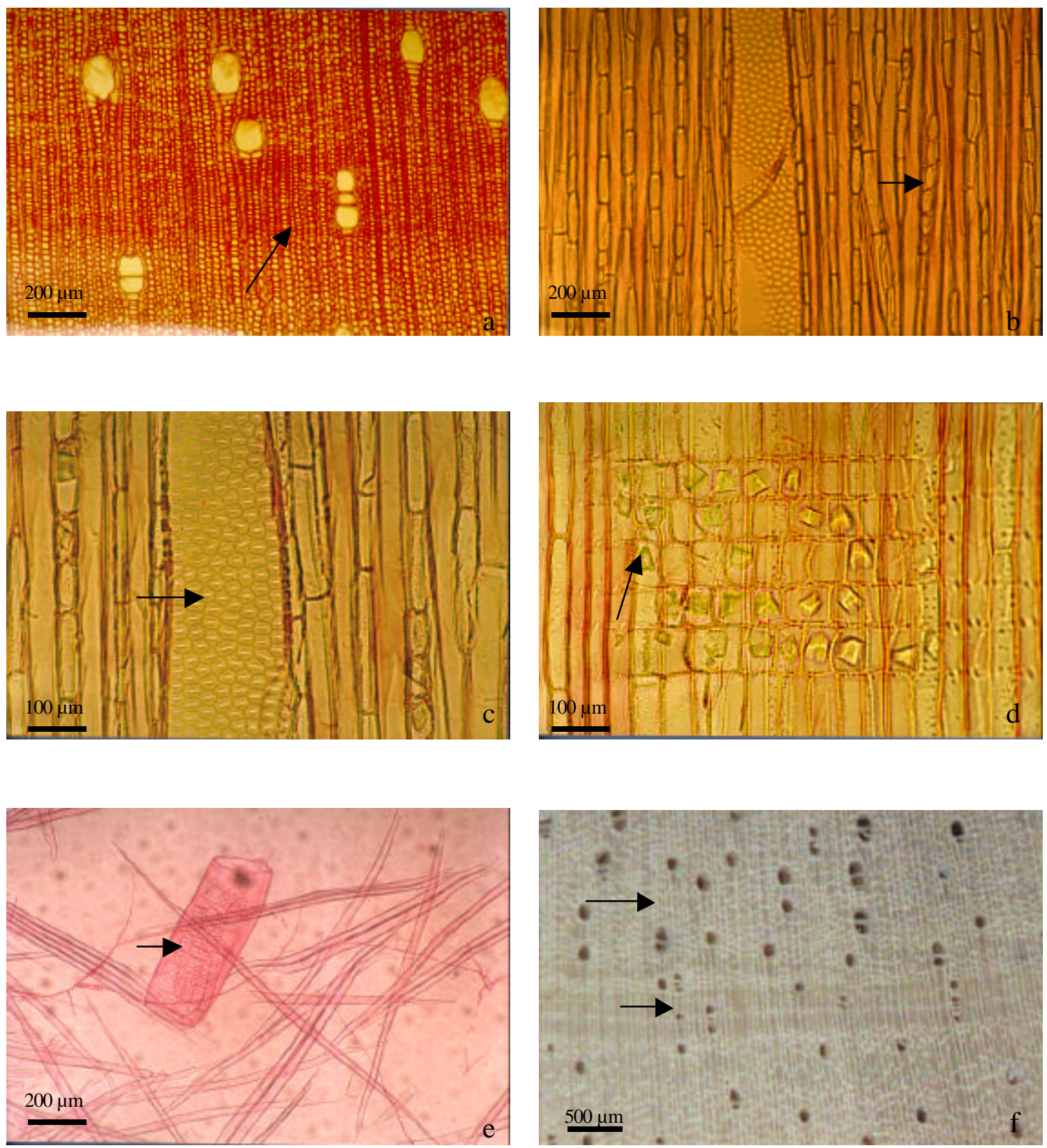

Figura 22 - Taineira, Alchornea sidifolia

a) plano transversal - camada de crescimento (seta); b) plano longitudinal tangencial - raio unisseriado (seta); c) plano longitudinal tangencial - pontoações intervasculares (seta); d) plano longitudinal radial - cristais em células do parênquima radial (seta); e) elemento de vaso (seta); f) plano transversal - parênquima axial (seta), camada de crescimento (seta). 

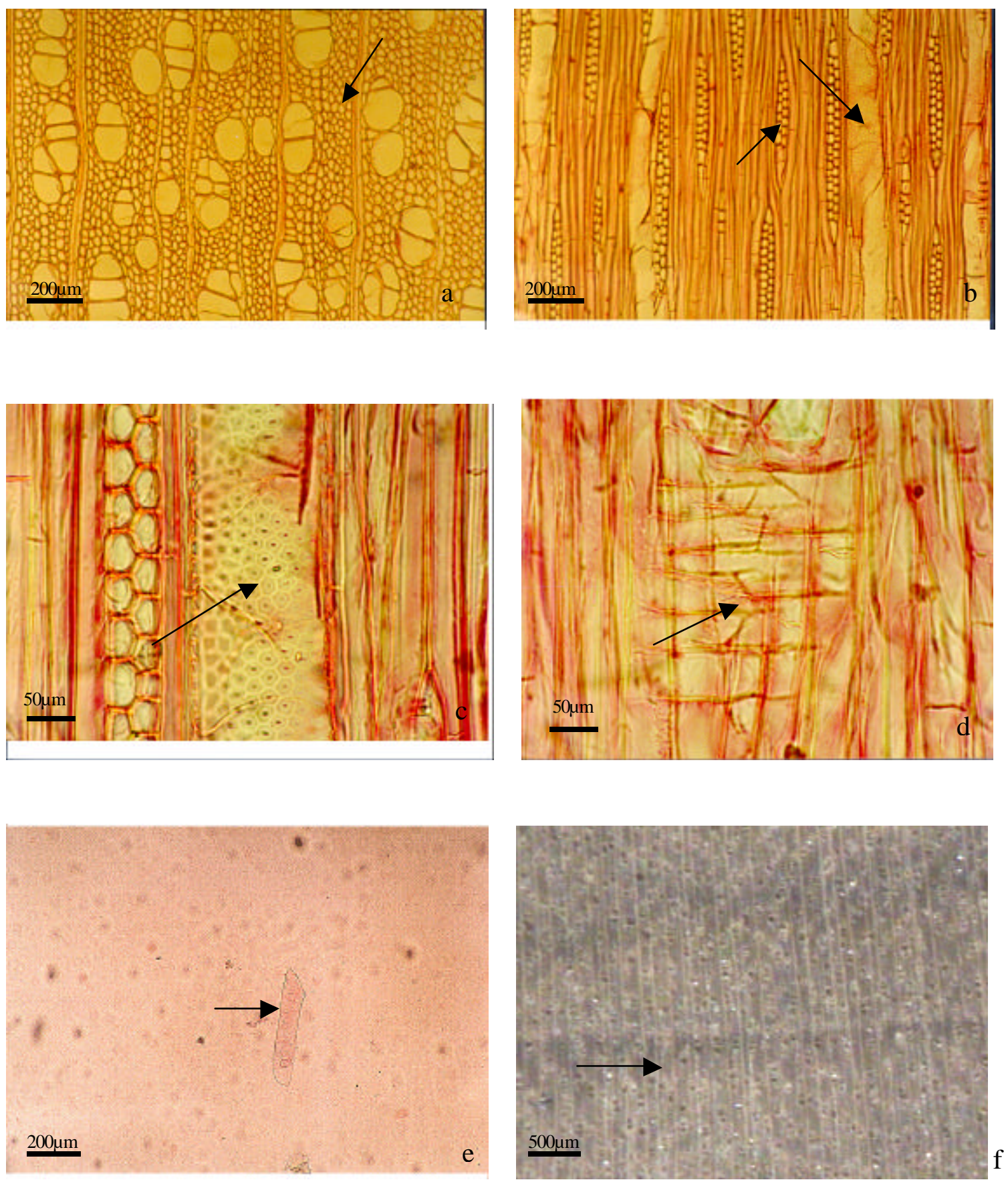

Figura 23 - Aroeira-vermelha, Schinus terebinthifolius

a) plano transversal - parênquima axial (seta); b) plano longitudinal tangencial - raio bisseriado (seta), vaso (seta); c) plano longitudinal tangencial - pontoações intervasculares (seta); d) plano longitudinal radial - raio heterocelular (seta); e) elemento de vaso (seta); f) plano transversal - camada de crescimento (seta). 

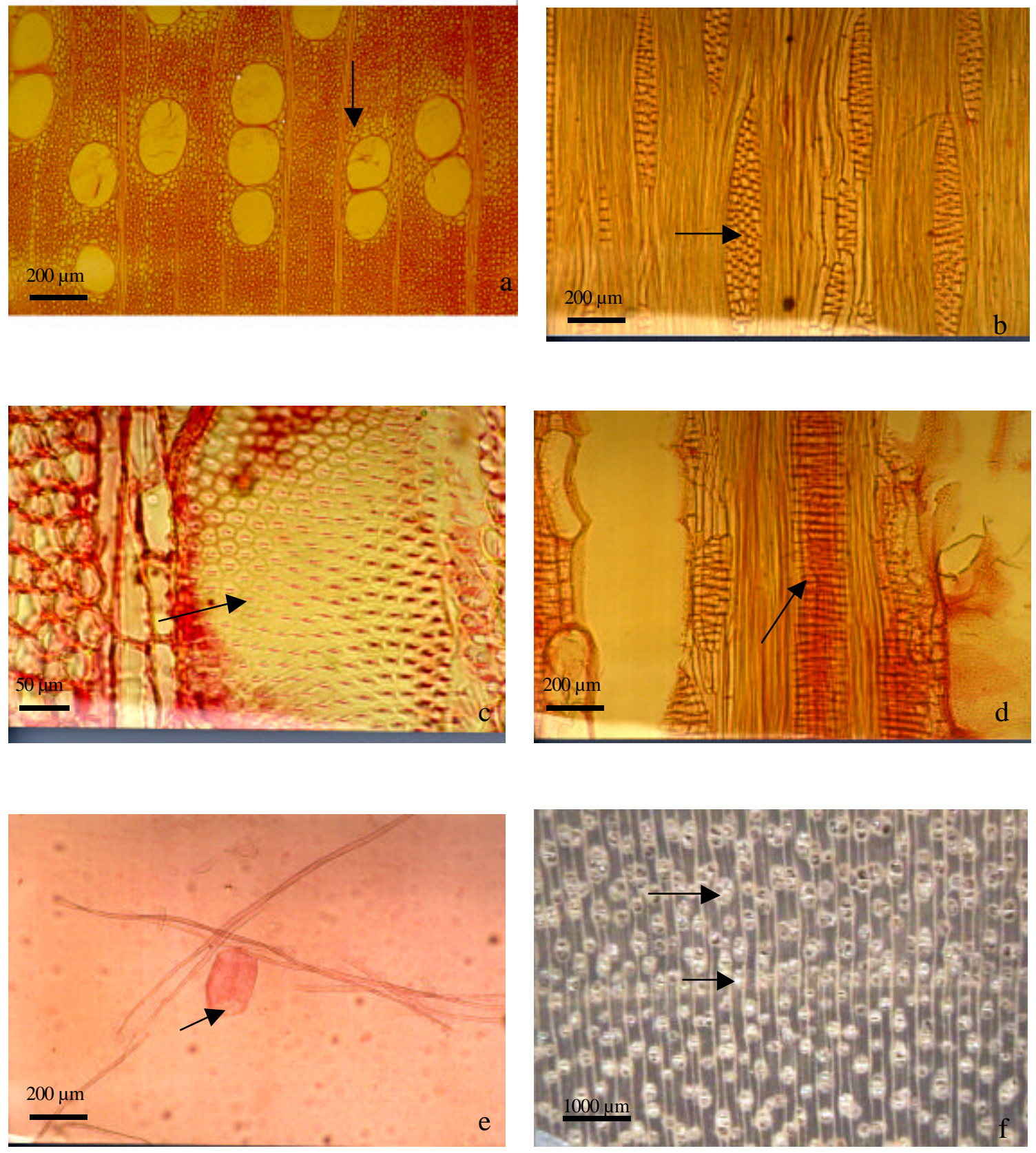

Figura 24 - Unha-de-vaca, Bauhinia forficata

a) plano transversal - parênquima axial (seta); b) plano longitudinal tangencial - raio trisseriado (seta); c) plano longitudinal tangencial - pontoações intervasculares (seta); d) plano longitudinal radial - raio heterocelular (seta); e) elemento de vaso (seta); f) plano transversal - vaso com tilos (seta), camada de crescimento (seta). 

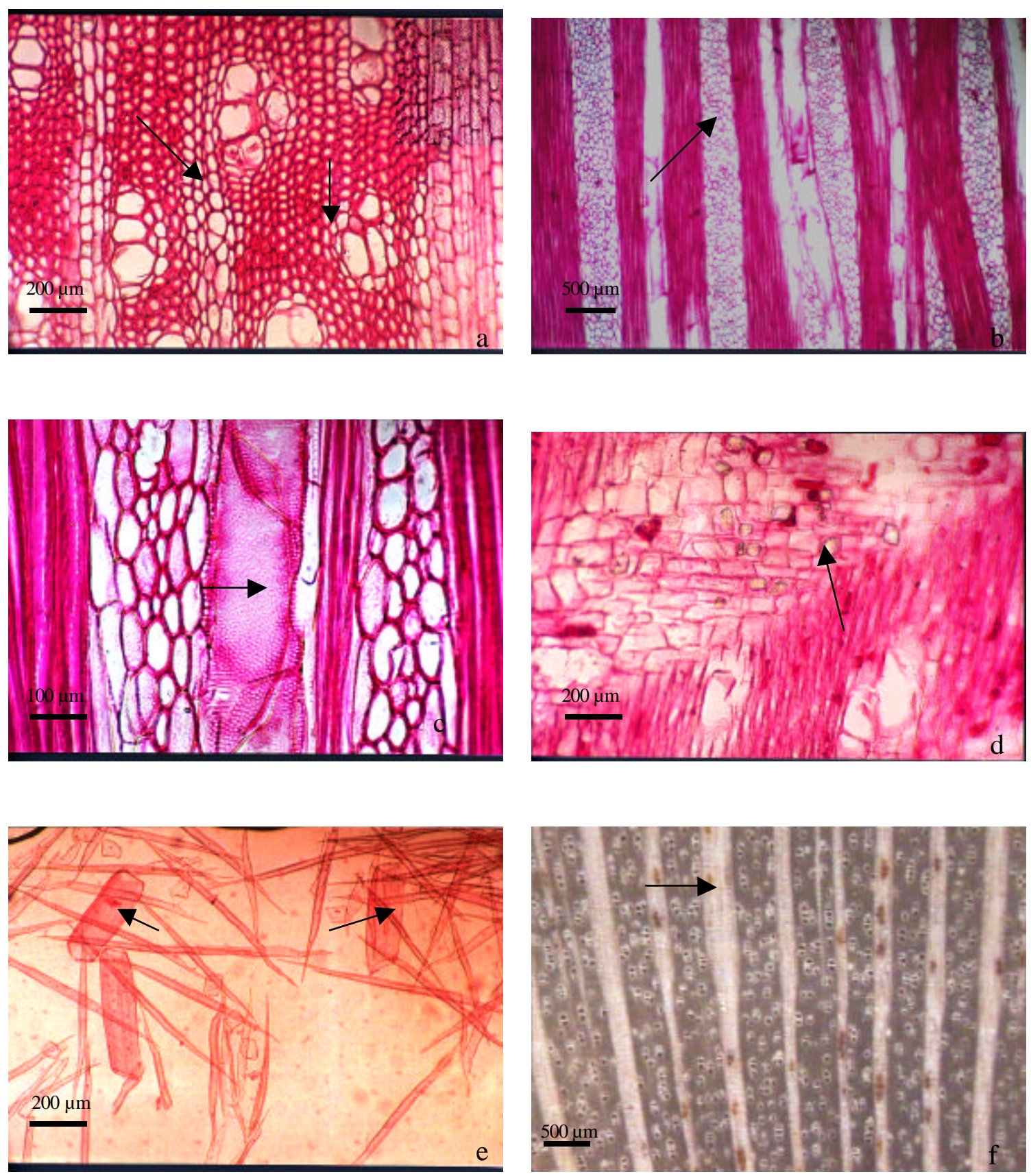

Figura 25 - Caraporoca, Rapanea umbellata

a) plano transversal - raio (seta), parênquima axial (seta); b) plano longitudinal tangencial raio multisseriado (seta); c) plano longitudinal tangencial - pontoações intervasculares (seta); d) plano longitudinal radial - raio homocelular com cristais (seta); e) elementos de vaso (setas); f) plano transversal - raio (seta). 

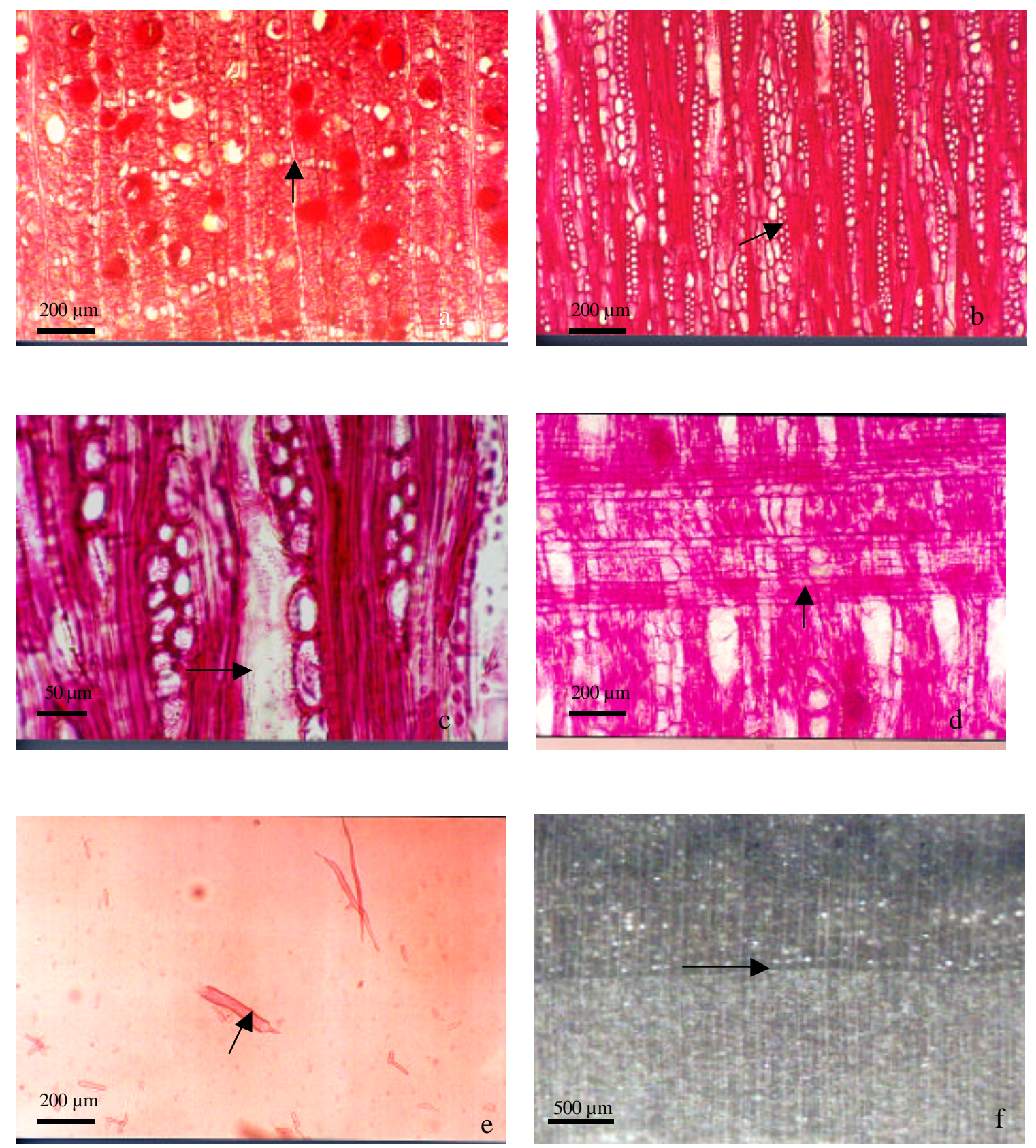

Figura 26 - Pitangueira, Eugenia uniflora

a) plano transversal - vaso (seta); b) plano longitudinal tangencial - raio bisseriado (seta); c) plano longitudinal tangencial - pontoações intervasculares (seta); d) plano longitudinal radial - raio homocelular (seta); e) elemento de vaso (seta); f) plano transversal - camada de crescimento (seta). 

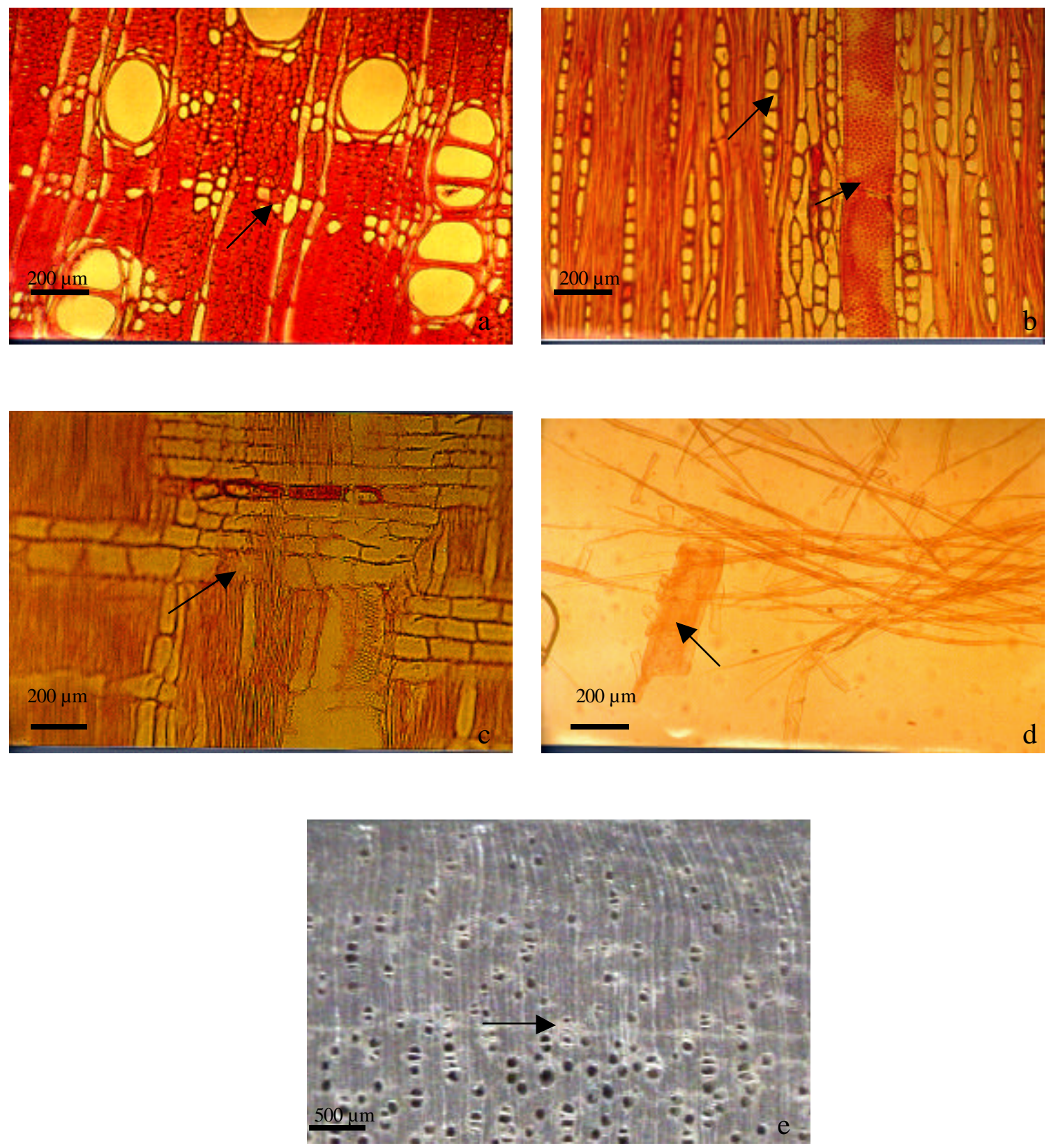

Figura 27 - Capitão-do-campo, Terminalia brasiliensis

a) plano transversal - parênquima axial (seta); b) plano longitudinal tangencial - raio unisseriado (seta), vaso (seta); c) plano longitudinal radial - raio homocelular (seta); e) elemento de vaso (seta); f) plano transversal - camada de crescimento (seta). 

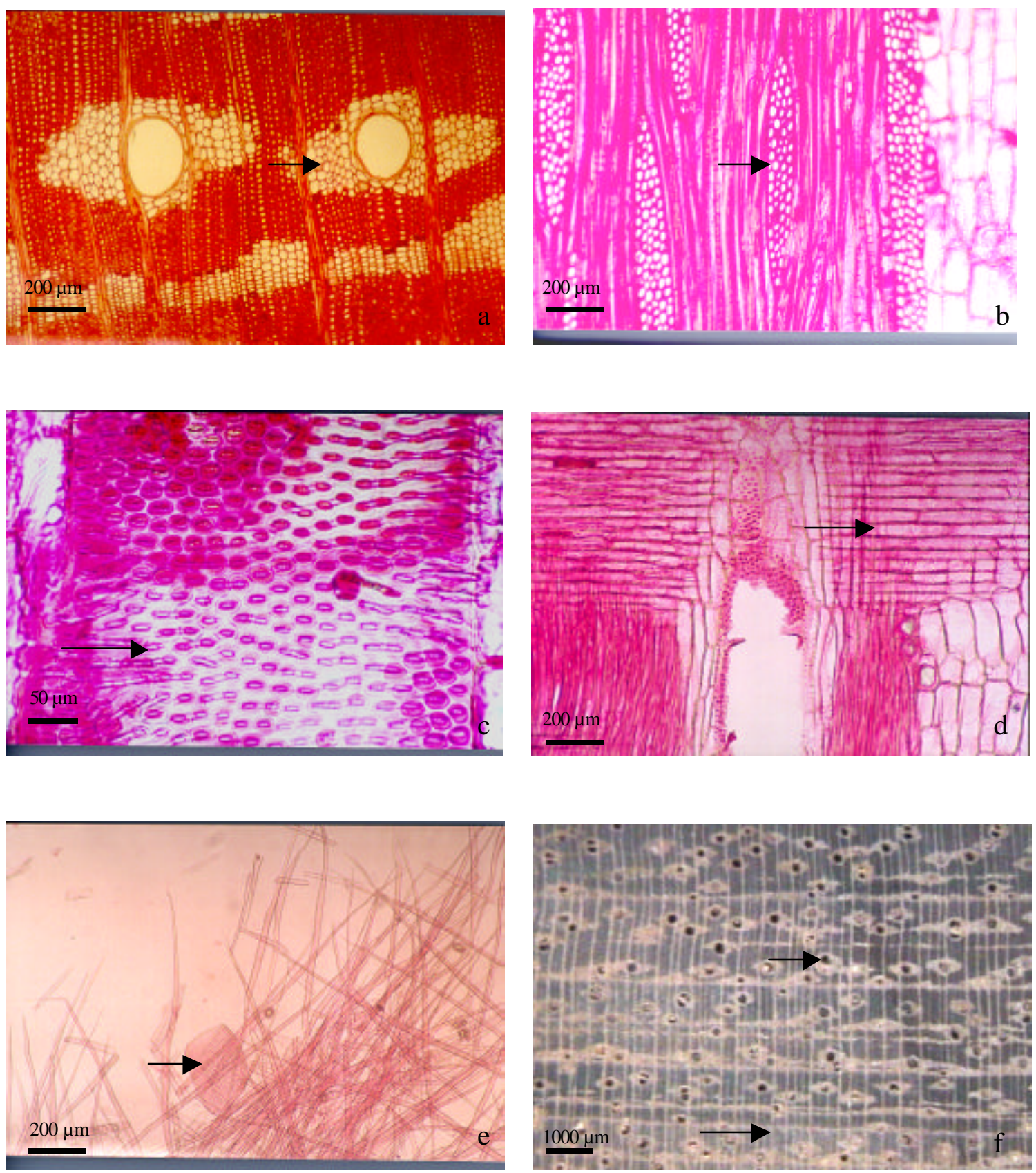

Figura 28 - Jatobá, Hymenaea courbaril

a) plano transversal - parênquima axial (seta); b) plano longitudinal tangencial - raio multisseriado (seta); c) plano longitudinal tangencial - pontoações intervasculares (seta); d) plano longitudinal radial - raio homocelular (seta); e) elemento de vaso (seta); f) plano transversal - vaso (seta), parênquima axial (seta). 

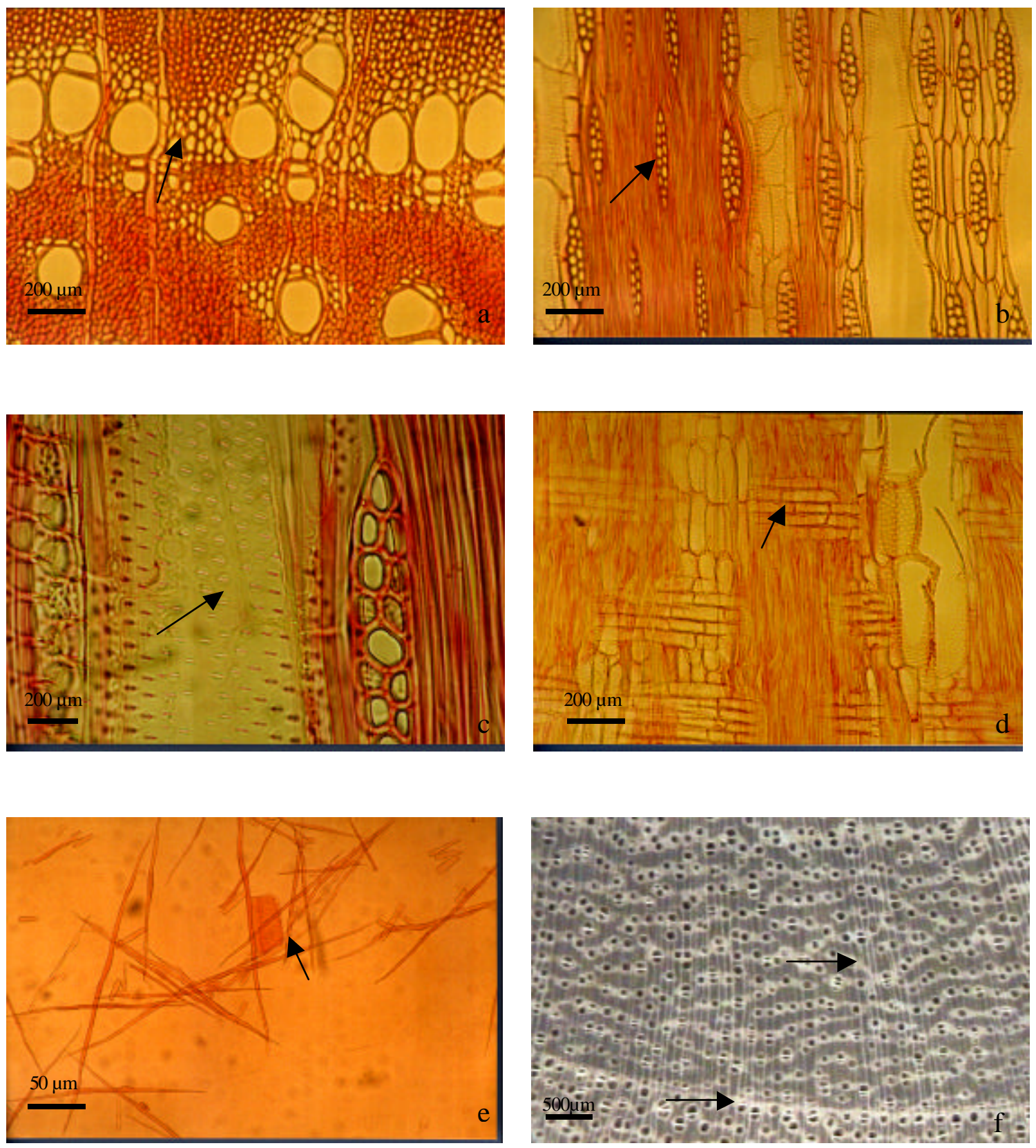

Figura 29 - Ipê-amarelo, Tabebuia chrysotricha

a) plano transversal - parênquima axial (seta); b) plano longitudinal tangencial - raio bisseriado (seta); c) plano longitudinal tangencial - pontoações intervasculares (seta); d) plano longitudinal radial - raio homocelular (seta); e) elemento de vaso (seta); f) plano transversal -parênquima axial (seta), camada de crescimento (seta). 

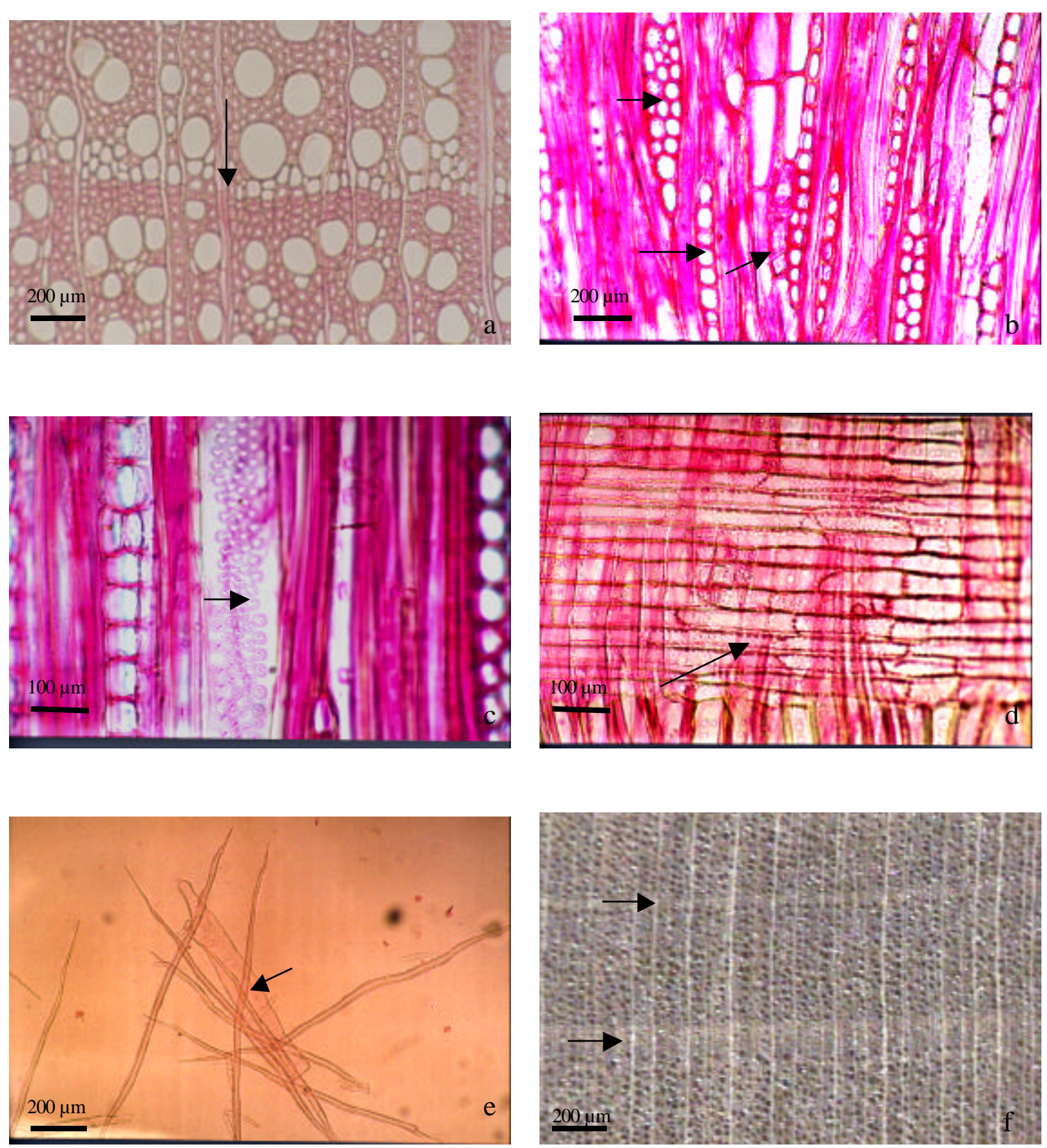

Figura 30 - Guatambu, Aspidosperma ramiflorum

a) plano transversal - parênquima axial (seta); b) plano longitudinal tangencial - raio unisseriado (seta), cristais em células do parênquima axial (seta); c) plano longitudinal tangencial - pontoações intervasculares (seta); d) plano longitudinal radial - raio homocelular (seta); e) elemento de vaso (seta); f) plano transversal - camadas de crescimento (setas). 

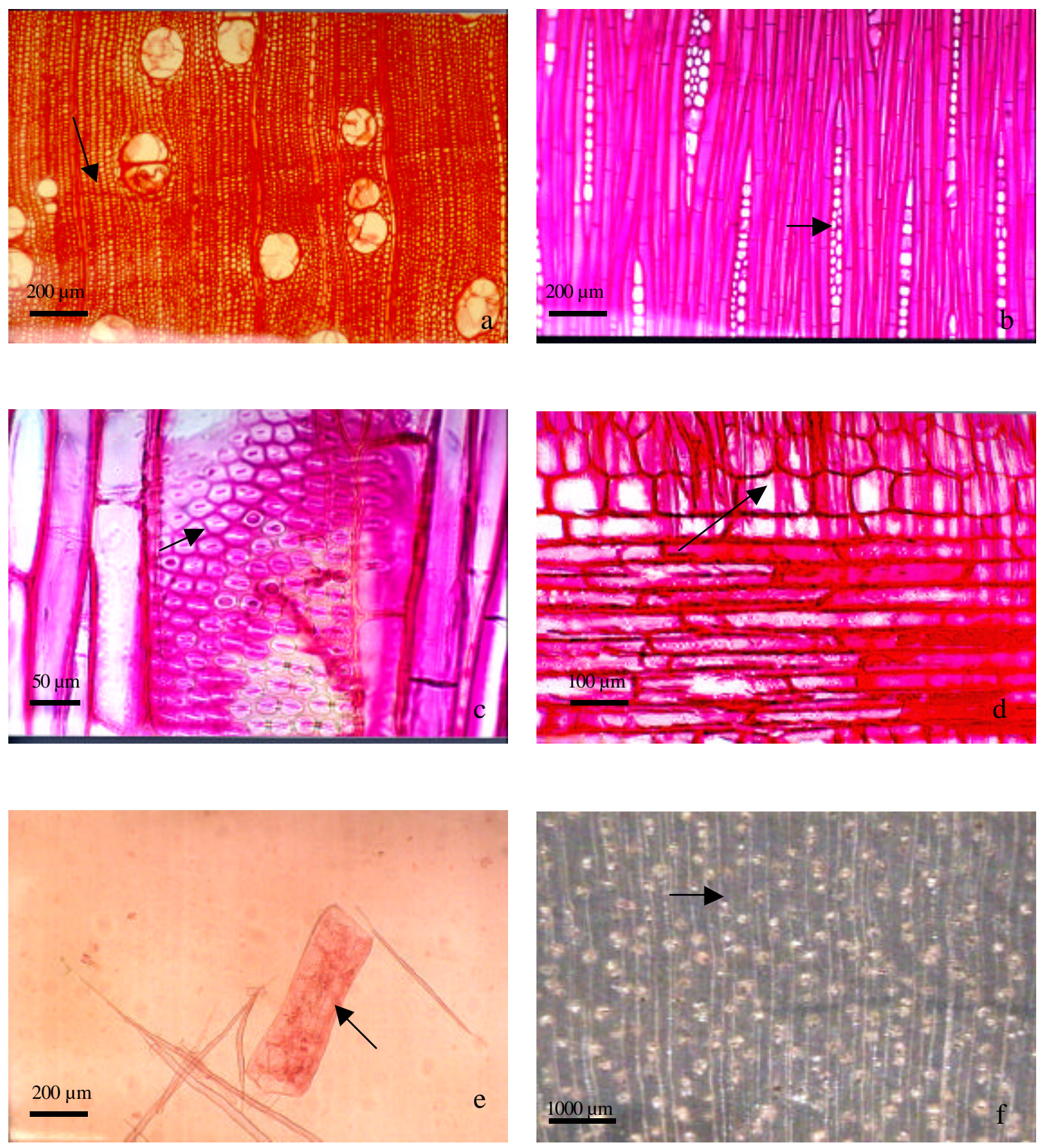

Figura 31 - Guaritá, Astronium graveolens

a) plano transversal - camada de crescimento (seta); b) plano longitudinal tangencial - raio bisseriado (seta); c) plano longitudinal tangencial - pontoações intervasculares (seta); d) plano longitudinal radial - raio heterocelular (seta); e) elemento de vaso (seta); f) plano transversal - vaso (seta). 

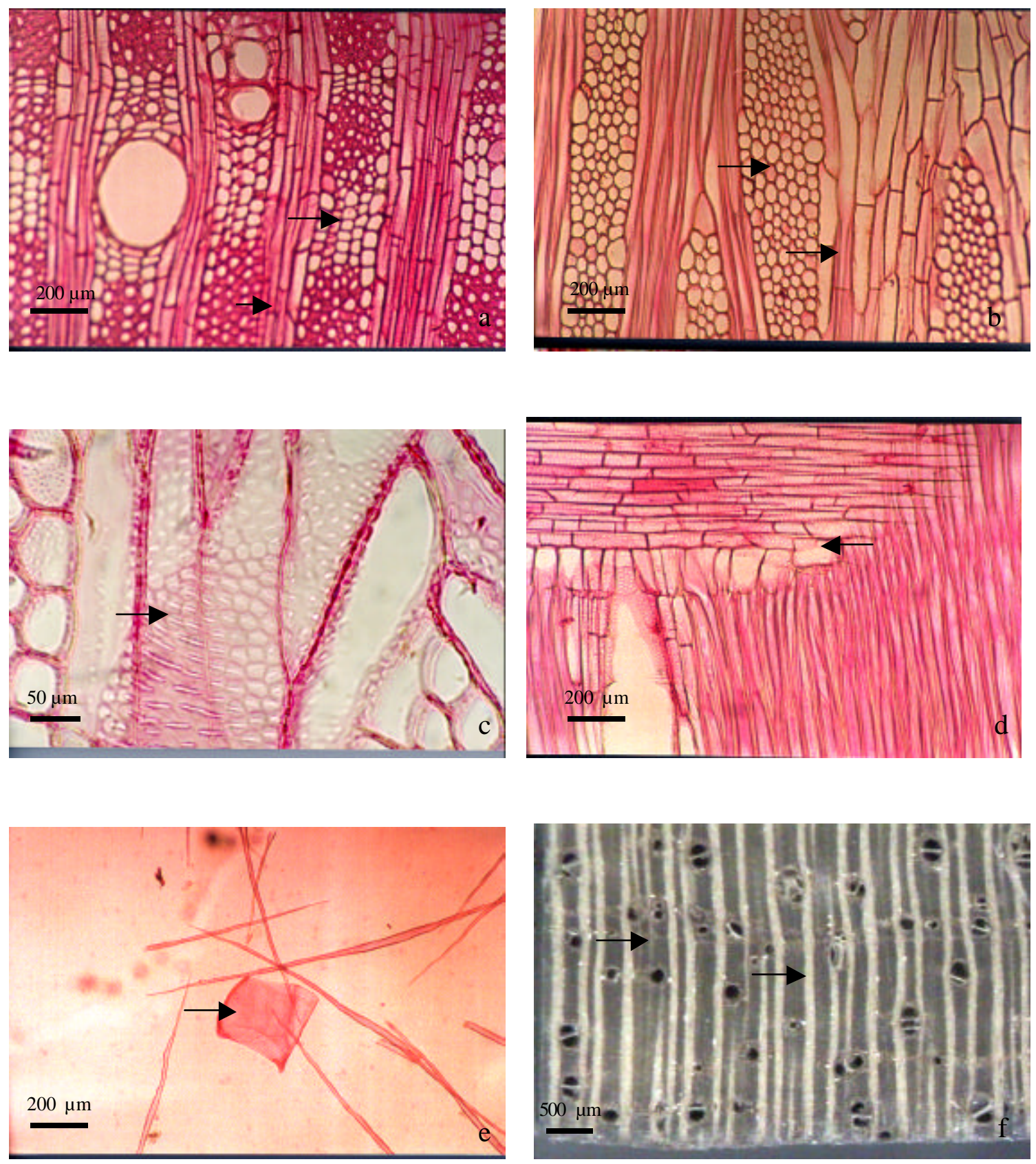

Figura 32 - Chá-de-bugre, Cordia sellowiana

a) plano transversal - parênquima axial (seta); b) plano longitudinal tangencial - raio multisseriado (seta), parênquima axial (seta); c) plano longitudinal tangencial - pontoações intervasculares (seta); d) plano longitudinal radial - raio heterocelular (seta); e) elemento de vaso (seta); f) plano transversal - vaso (seta), raio (seta). 

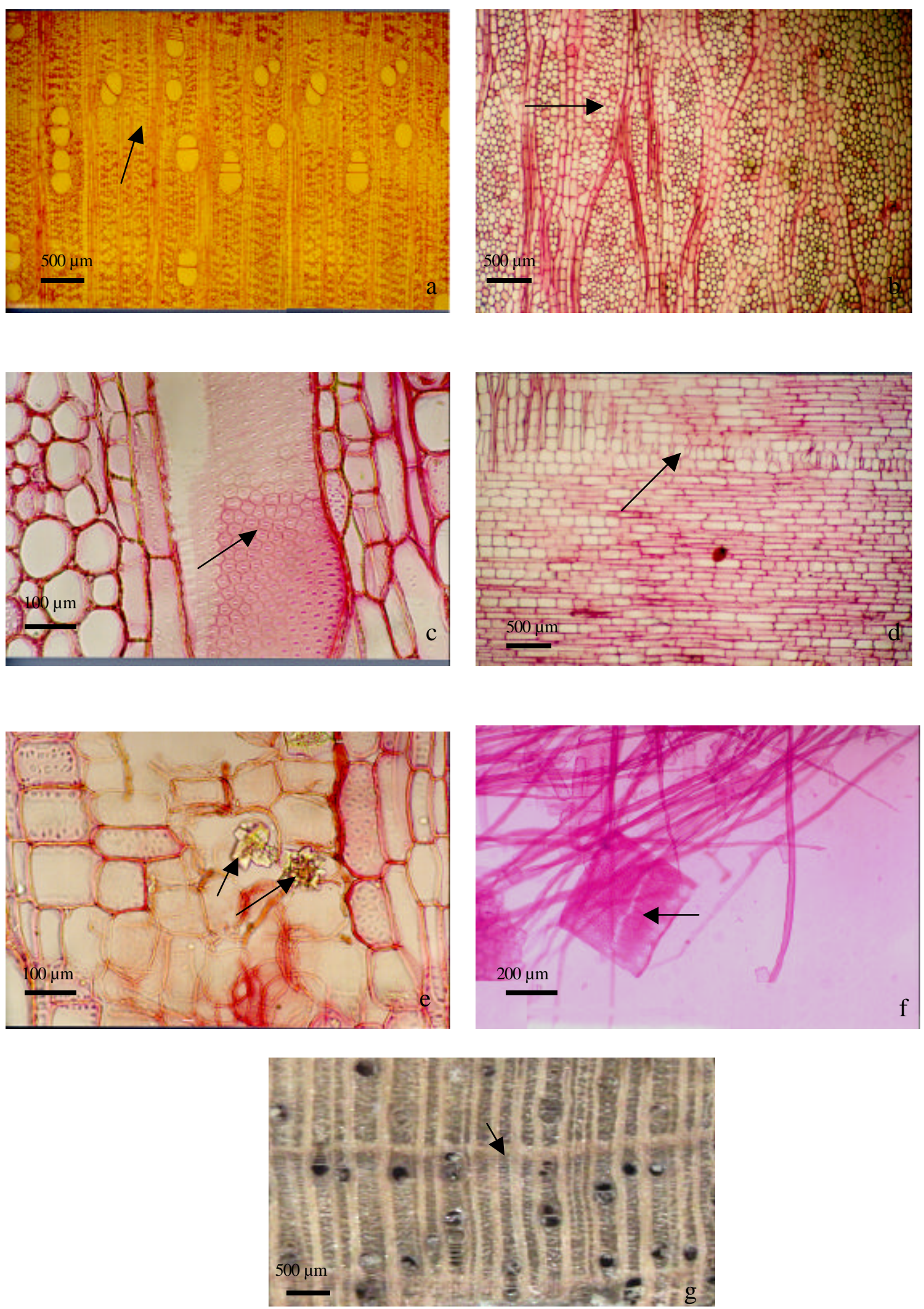

Figura $n^{\circ} 33$ - Embiruçu, Bombax grandiflorum

a) pano transversal - vaso (seta); b) plano longitudinal tangencial - raio multisseriado (seta); c) plano longitudinal tangencial - pontoações intervasculares (seta); d) plano longitudinal radial - raio heterocelular (seta); e) plano longitudinal radial - cristais em células do parênquima radial; f) elemento de vaso (seta); g) plano transversal - camada de crescimento (seta). 

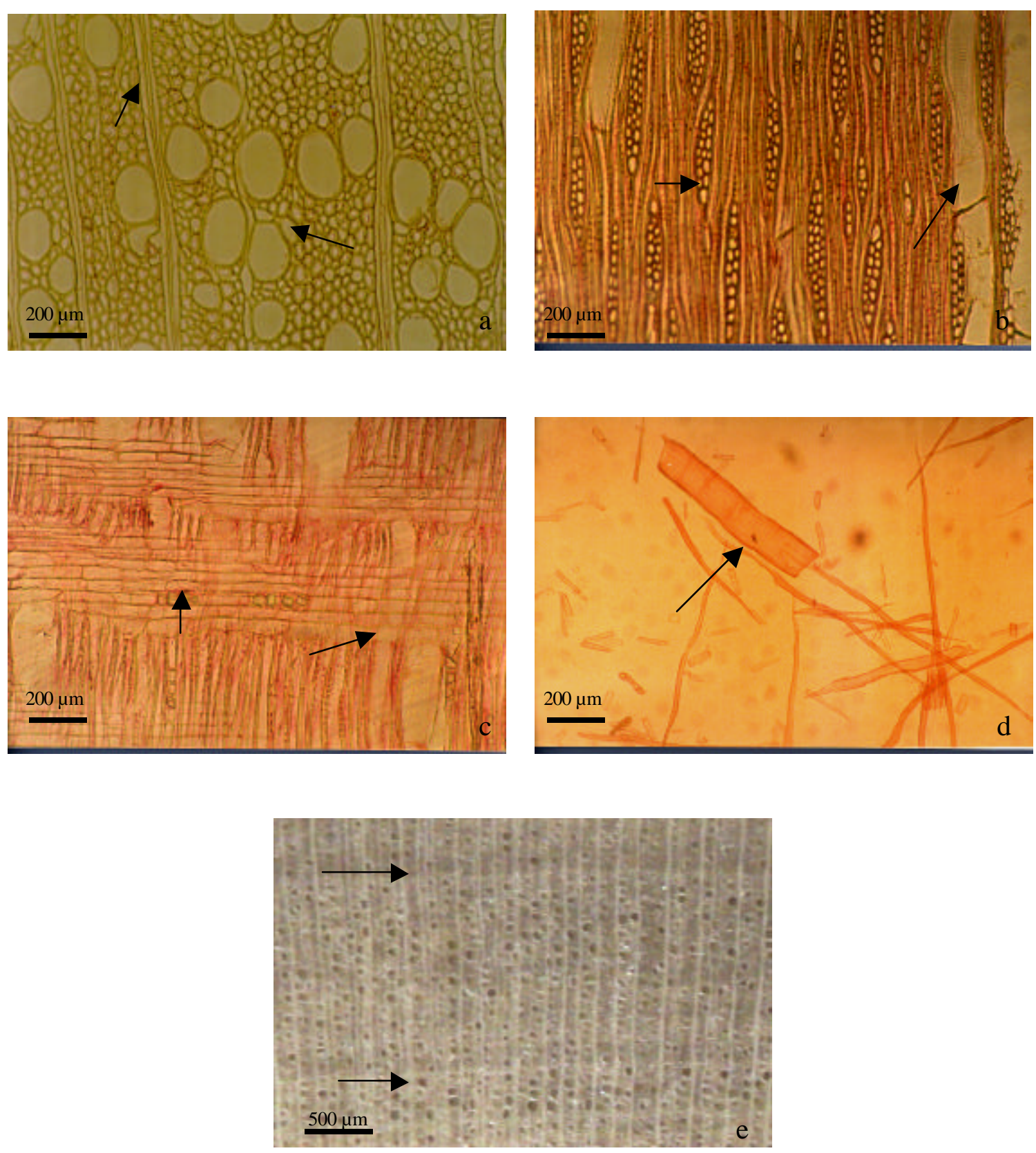

Figura 34 - Peroba-poca, Aspidosperma cylindrocarpon

a) plano transversal - raio (seta), parênquima axial (seta); b) plano longitudinal tangencial raio trisseriado (seta), vaso (seta); c) plano longitudinal radial - raio homocelular com cristais (setas); d) elemento de vaso (seta); e) plano transversal - camadas de crescimento (setas). 

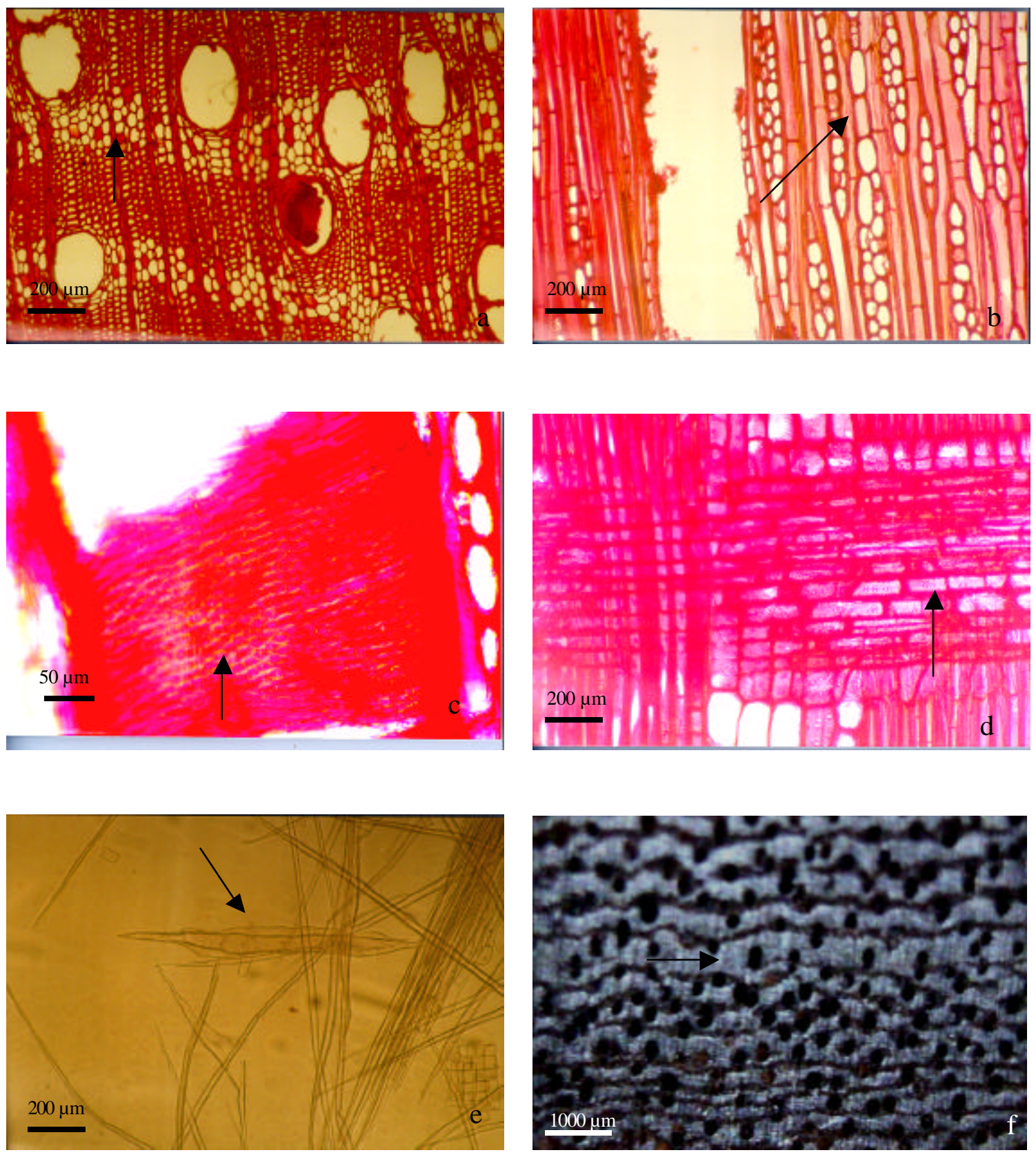

Figura 35 - Canjarana, Cabralea canjerana

a) plano transversal - parênquima axial (seta); b) plano longitudinal tangencial - raio bisseriado (seta); c) plano longitudinal tangencial - pontoações intervasculares (seta); d) plano longitudinal radial - raio heterocelular (seta); e) elemento de vaso (seta); f) plano transversal - parênquima axial (seta). 

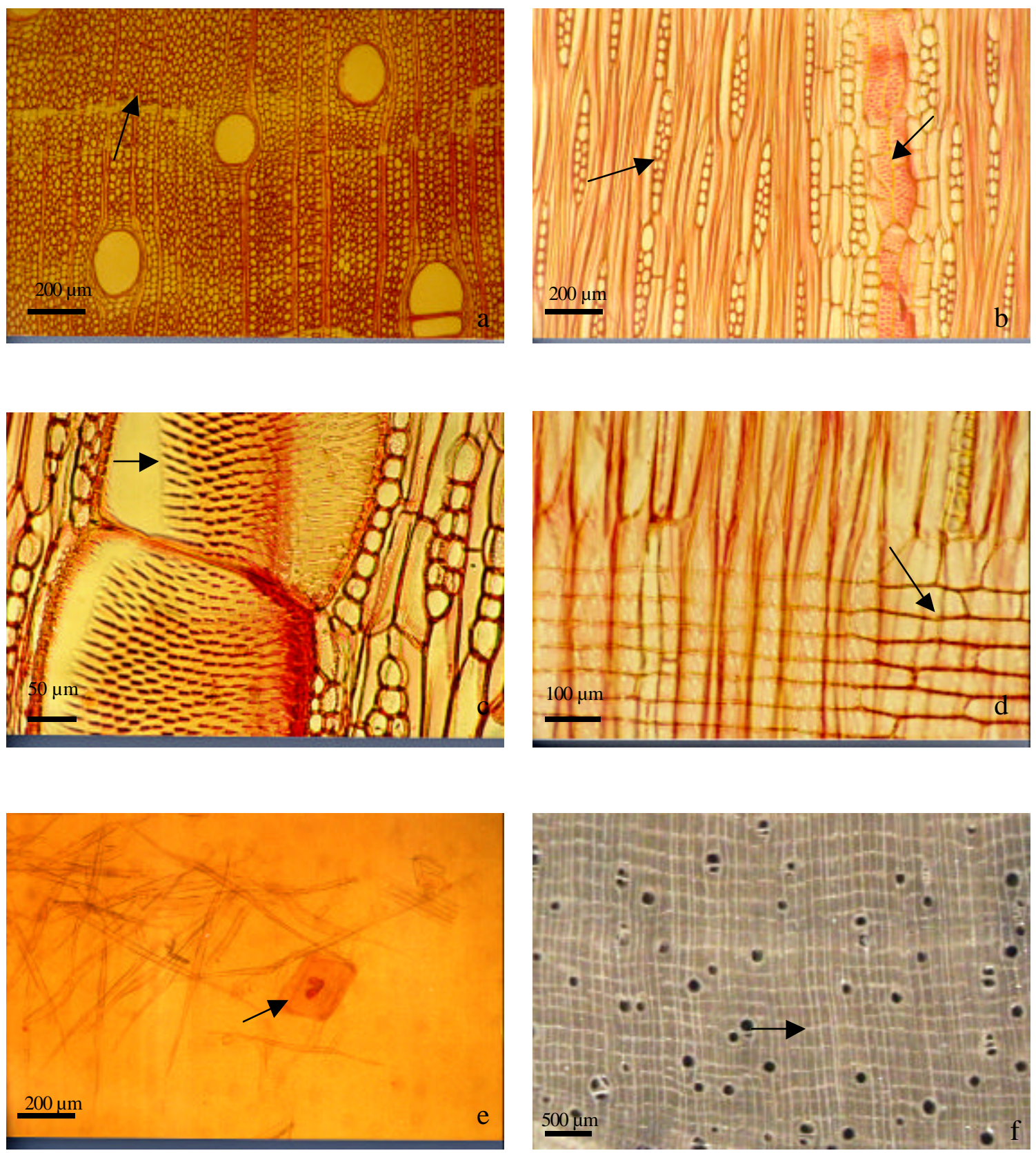

Figura 36 - Bico-de-pato, Machaerium aculeatum

a) plano transversal - parênquima axial (seta); b) plano longitudinal tangencial - raio bisseriado (seta); c) plano longitudinal tangencial - pontoações intervasculares (seta); d) plano longitudinal radial - raio heterocelular (seta); e) elemento de vaso (seta); f) plano transversal - parênquima axial (seta). 

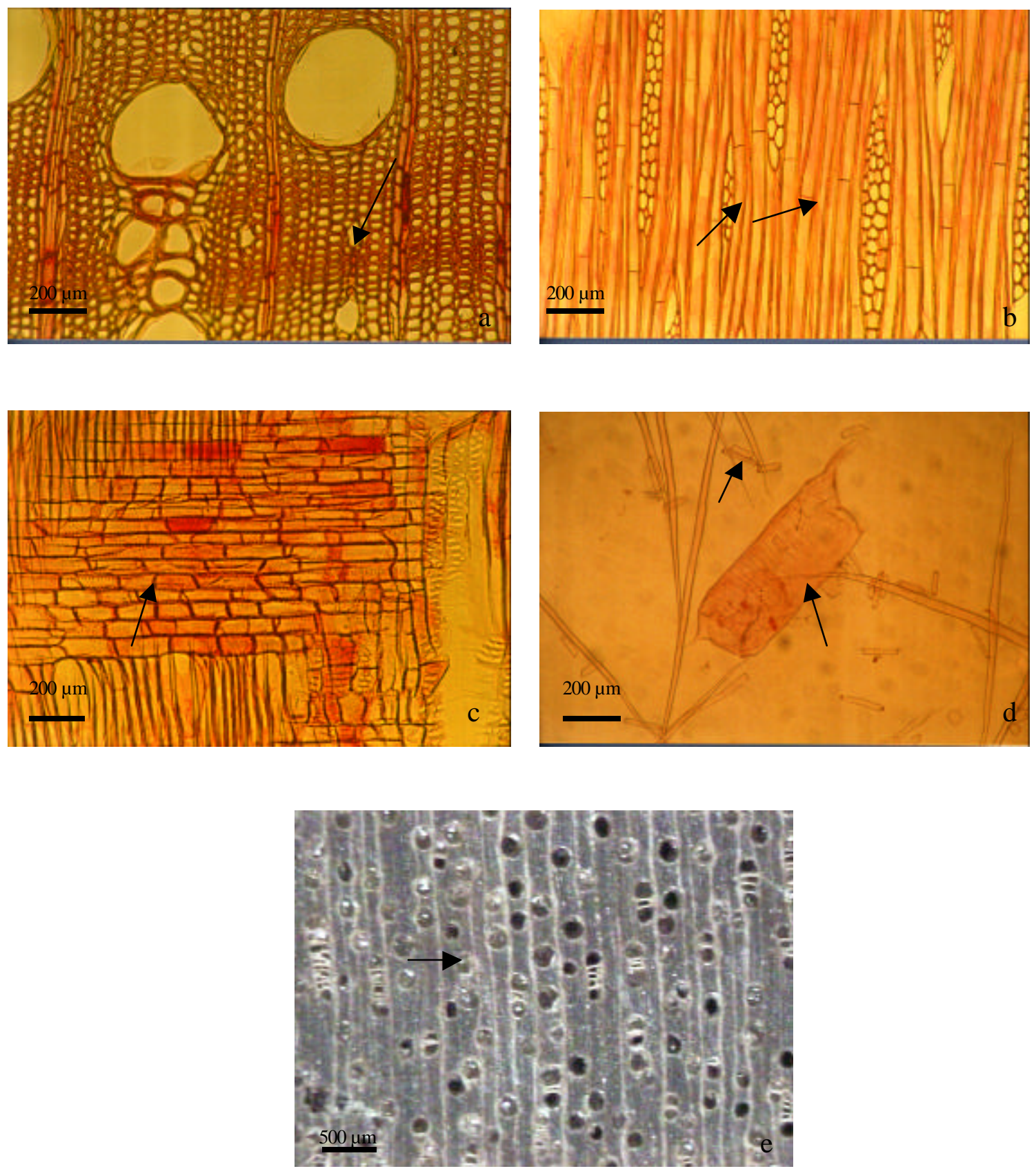

Figura 37 - Guaicá, Ocotea puberula

a) plano transversal - parênquima axial (seta); b) plano longitudinal tangencial - raio bisseriado (seta), fibra septada (seta); c) raio homocelular (seta); d) elementos de vaso (setas); e) plano transversal - vaso (seta). 

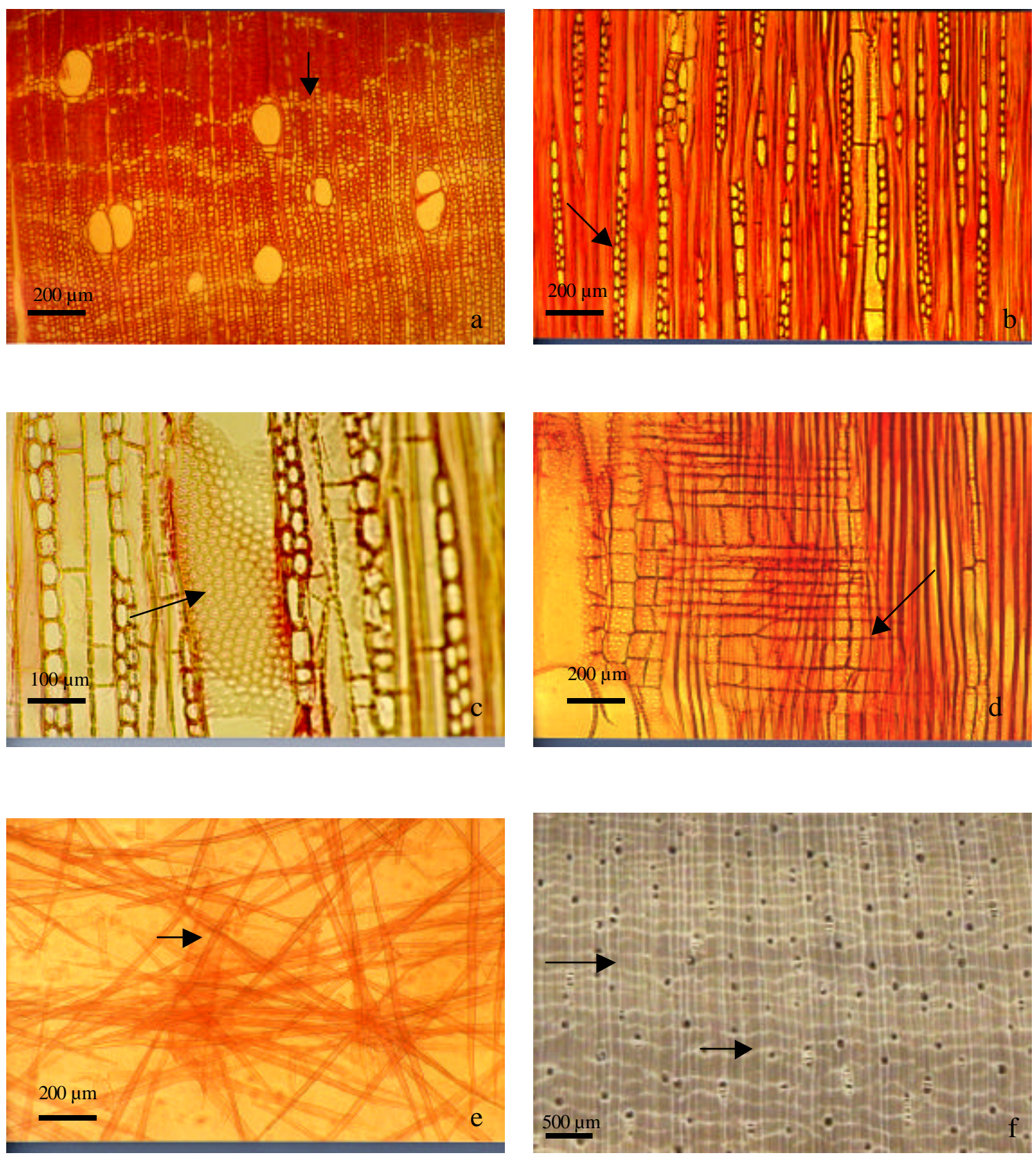

Figura 38 - Capixingui, Croton sp.

a) plano transversal - parênquima axial (seta); b) plano longitudinal tangencial - raio bisseriado (seta); c) plano longitudinal tangencial - pontoações intervasculares (seta); d) plano longitudinal radial - raio heterocelular (seta); e) elemento de vaso (seta); f) plano transversal - parênquima axial (setas). 

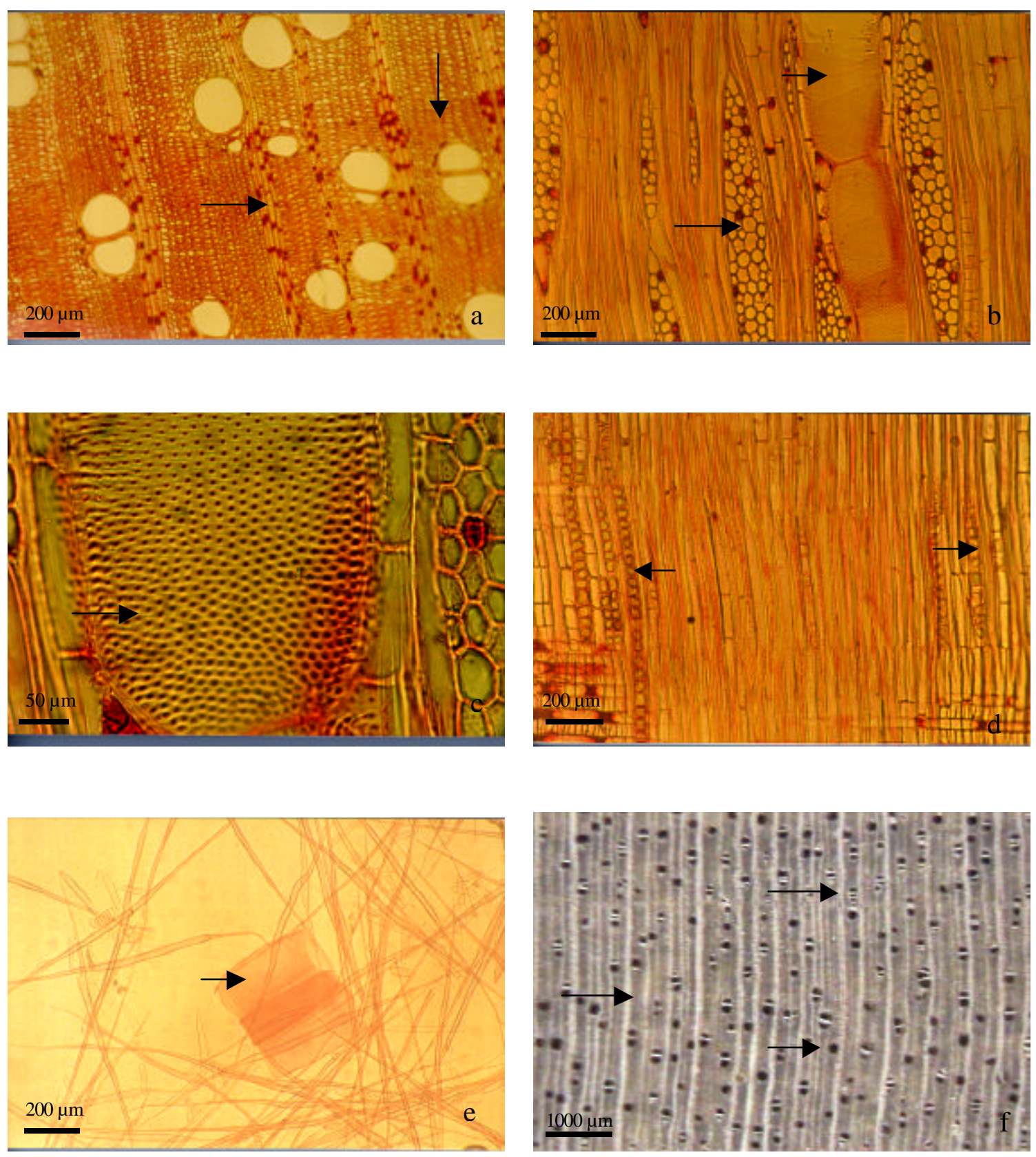

Figura 39 - Mutambo, Guazuma ulmifolia

a) plano transversal - raio (seta); b) plano longitudinal tangencial - raio multisseriado (seta);

c) plano longitudinal tangencial - pontoações intervasculares (seta); d) plano longitudinal radial - cristais em células do parênquima axial (seta); e) elemento de vaso (seta); f) plano transversal - raio (setas). 

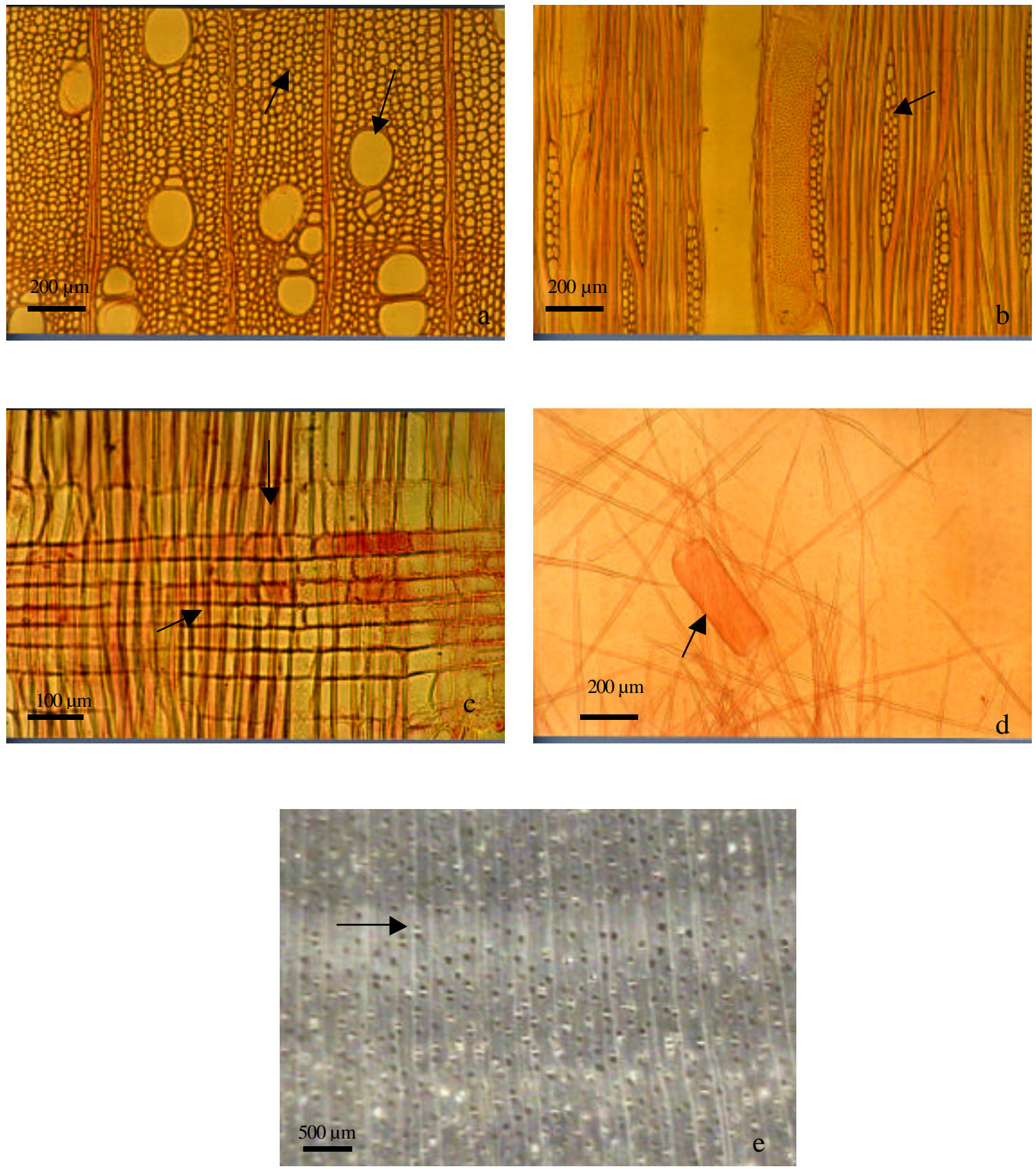

Figura 40 - Mamica-de-porca, Zanthoxylum rhoifolium

a) plano transversal - fibras (seta), vaso (seta); b) plano longitudinal tangencial - raio trisseriado (seta); c) plano longitudinal radial - raio heterocelular (seta); d) elemento de vaso (seta); e) plano transversal - camada de crescimento (seta). 

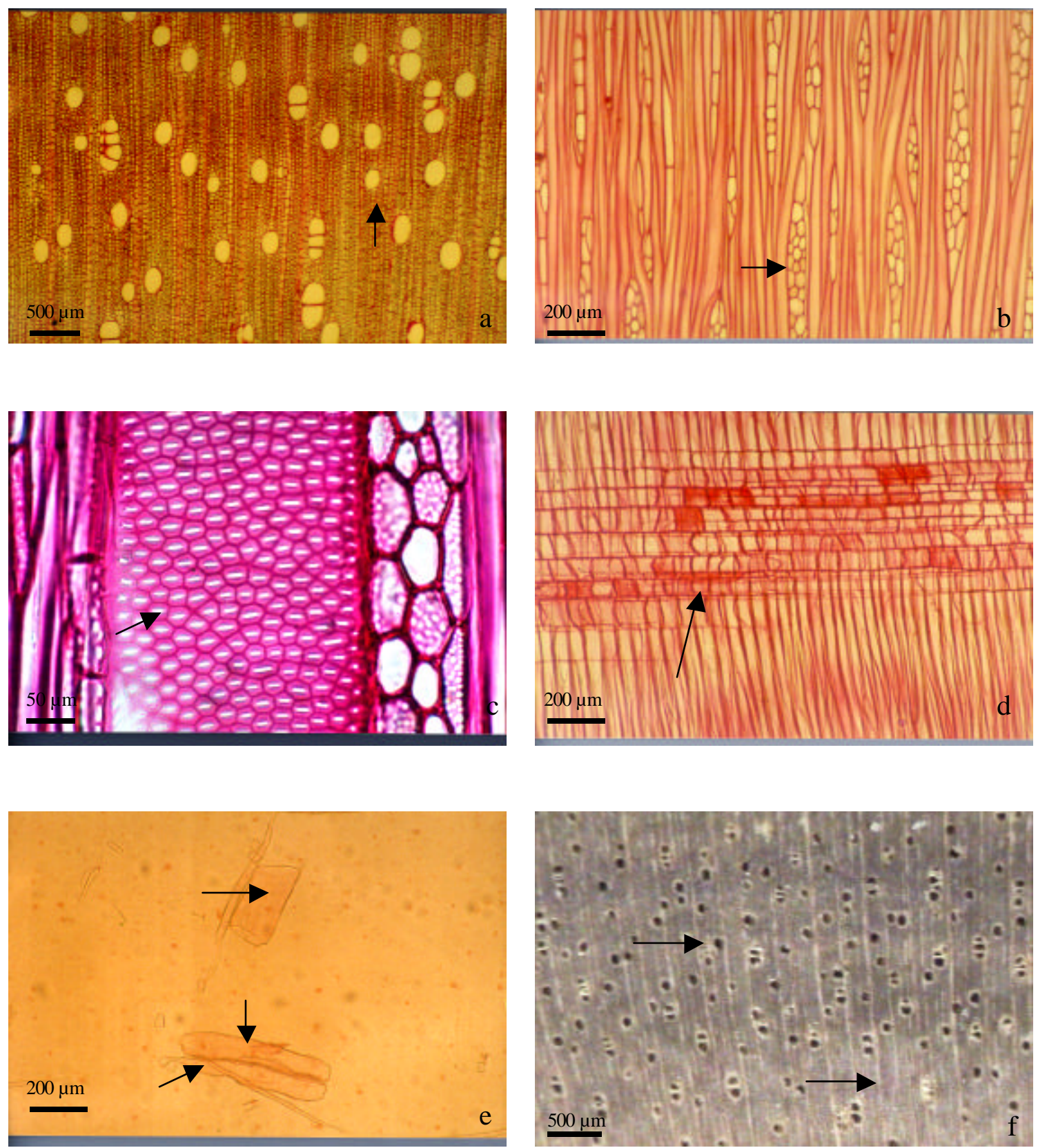

Figura 41 - Candiúba, Trema micrantha

a) plano transversal - vaso (seta); b) plano longitudinal tangencial - raio trisseriado (seta); c) plano longitudinal tangencial - pontoações intervasculares (seta); d) plano longitudinal radial - raio homocelular (seta); e) elementos de vaso (setas); f) plano transversal - vaso (seta), raio (seta). 